Marquette University

e-Publications@Marquette

$1-1-2015$

Chemoselective Formation of Unsymmetrically Substituted Ethers from Catalytic Reductive Coupling of Aldehydes and Ketones with Alcohols in Aqueous Solution

Nishantha Kumara Kalutharage

Marquette University

Chae S. Yi

Marquette University, chae.yi@marquette.edu

Accepted version. Organic Letters, Vol. 17, No. 7 (2015): 1778-1781. DOI. (C) 2015 American

Chemical Society. Used by permission 


\title{
Chemoselective Formation of Unsymmetrically Substituted Ethers from Catalytic Reductive Coupling of Aldehydes and Ketones with Alcohols in Aqueous Solution
}

\author{
Nishantha Kalutharage \\ Department of Chemistry, Marquette University, \\ Milwaukee, WI \\ Chae S. Yi \\ Department of Chemistry, Marquette University, \\ Milwaukee, WI
}

Organic Letters, Vol 17, No. 7 (2015): pg. 1778-1781. DOI. This article is @ American Chemical Society and permission has been granted for this version to appear in e-Publications@Marquette. American Chemical Society does not grant permission for this article to be further copied/distributed or hosted elsewhere without the express permission from American Chemical Society. 


\section{Abstract}

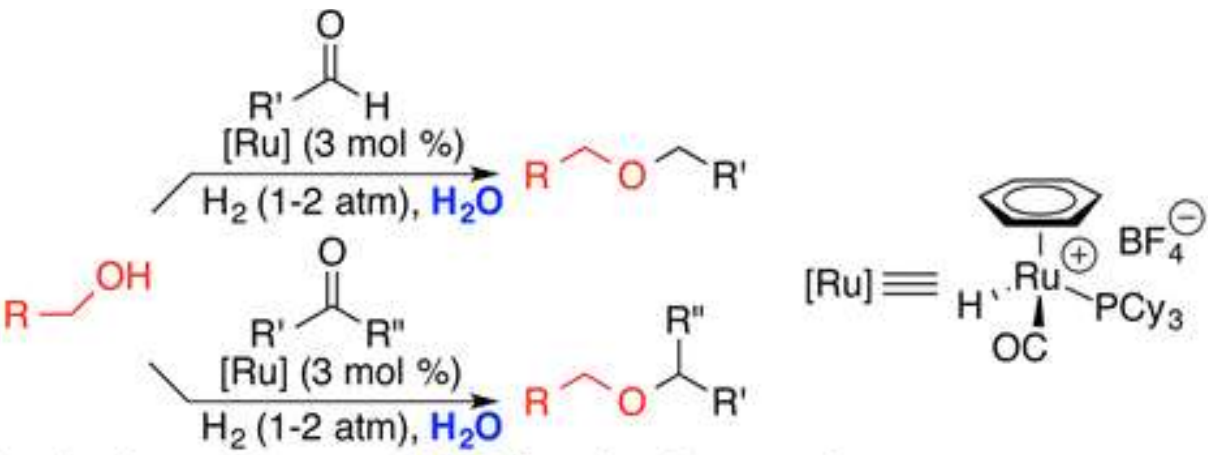

- Broad substrate scope and high functional group tolerance

- High selectivity for unsymmerical ethers without forming wasteful byproducts

- Employ $\mathrm{H}_{2}$ as the reducing agent and water as the solvent

A well-defined cationic $\mathrm{Ru}-\mathrm{H}$ complex catalyzes reductive etherification of aldehydes and ketones with alcohols. The catalytic method employs environmentally benign water as the solvent and cheaply available molecular hydrogen as the reducing agent to afford unsymmetrical ethers in a highly chemoselective manner.

Etherification of oxygenated organic compounds is an ubiquitous organic transformation in both industrial and fine chemical syntheses. ${ }^{1}$ Strong Brønsted acid and heterogeneous acid catalysts are commonly employed for industrial-scale etherification of alcohols, ${ }^{2}$ while the Williamson ether synthesis has long been used for laboratory-scale synthesis of unsymmetrically substituted ethers. ${ }^{3}$ Seminal catalytic CO bond formation methods such as Ullmann- and Mitsunobu-type coupling reactions have been extensively utilized for the synthesis of aryl-substituted ethers. ${ }^{4}$ More recently, a number of highly effective catalytic methods for unsymmetrical ethers have been developed from use of hydroalkoxylation of alkenes ${ }^{5}$ and oxidative $\mathrm{C}-\mathrm{H}$ alkoxylation of arenes. ${ }^{6}$ The reductive etherification of carbonyl compounds has also been shown to be a synthetically powerful etherification method, but this method requires a stoichiometric amount of silane as the reducing agent. ${ }^{7}$ Despite such remarkable progress, these catalytic etherification methods pose major synthetic and environmental problems in that they employ reactive reagents such as inorganic acids and organic alkoxide substrates, which result in the formation of copious amounts of wasteful byproducts. From the viewpoint of achieving green and sustainable catalysis, the development of an efficient and broadly applicable catalytic etherification process that

Organic Letters, Vol 17, No. 7 (2015): pg. 1778-1781. DOI. This article is @ American Chemical Society and permission has been granted for this version to appear in e-Publications@Marquette. American Chemical Society does not grant permission for this article to be further copied/distributed or hosted elsewhere without the express permission from American Chemical Society. 
does not form any wasteful byproducts remains a high priority goal, particularly for the synthesis of unsymmetrically substituted ethers. ${ }^{8}$

We recently discovered that a well-defined cationic ruthenium hydride complex $\left[\left(\mathrm{C}_{6} \mathrm{H}_{6}\right)\left(\mathrm{PCy}_{3}\right)(\mathrm{CO}) \mathrm{RuH}^{+} \mathrm{BF}_{4}^{-}(\mathbf{1})\right.$ is a highly selective catalyst precursor for the etherification of two different alcohols to form unsymmetrically substituted ethers. ${ }^{9}$ While this etherification provides unsymmetrical ethers without forming any wasteful byproducts, it was not effective for the coupling between electronically similar or sterically demanding aliphatic alcohols, as it gave a mixture of symmetrical and unsymmetrical ethers. In an effort to extend the scope of the etherification reaction, we explored the analogous reductive coupling reactions of carbonyl compounds. Herein, we report a highly chemoselective formation of unsymmetrically substituted ether products from the reductive coupling of aldehydes and ketones with alcohols. The "green" features of the catalytic method are that it employs cheaply available molecular hydrogen as the reducing agent, tolerates a number of common functional groups, and uses environmentally benign water as the solvent.

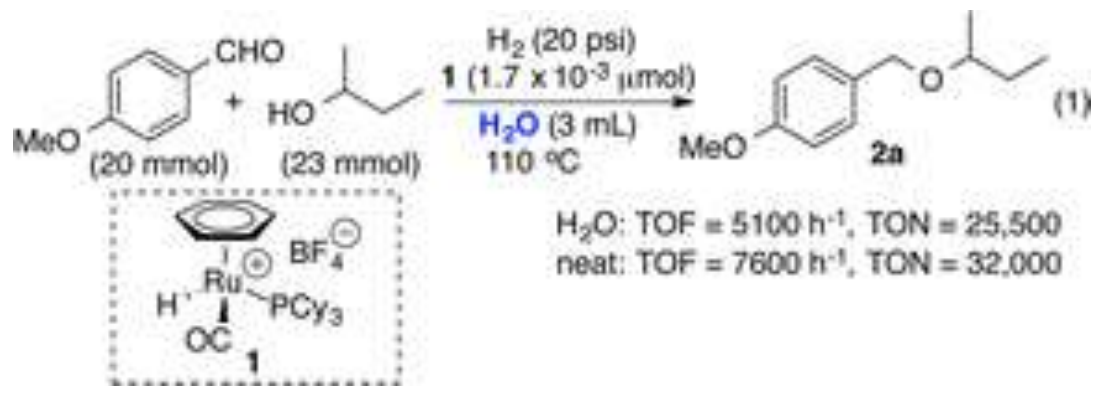

We initially screened the catalyst activity of the ruthenium complex 1 for the reductive coupling reaction of 2-butanol with 4methoxybenzaldehyde (eq 1 ). While searching for a suitable set of conditions, we were delighted to discover that $\mathrm{H}_{2}$ (1-2 atm) can be used as the reducing agent and water as the solvent. Under these conditions, complex $\mathbf{1}$ was found to exhibit distinctively high activity and selectivity in forming the ether product $\mathbf{2 a}$ among screened ruthenium and acid catalysts, as analyzed by both GC and NMR spectroscopic methods (Table S1, Supporting Information (SI)). Since most reductive etherifications of carbonyl compounds require a stoichiometric amount of silane or borane as the reducing agent, ${ }^{7}$ our

Organic Letters, Vol 17, No. 7 (2015): pg. 1778-1781. DOI. This article is @ American Chemical Society and permission has been granted for this version to appear in e-Publications@Marquette. American Chemical Society does not grant permission for this article to be further copied/distributed or hosted elsewhere without the express permission from American Chemical Society. 
catalytic method on using molecular $\mathrm{H}_{2}$ is quite beneficial from both synthetic and environmental points of view.

We measured the catalytic activity of $\mathbf{1}$ for the etherification reaction. In a Fisher-Porter pressure bottle, the treatment of 4methoxybenzaldehyde (20 mmol) with 2-butanol $(23 \mathrm{mmol})$ and $\mathrm{H}_{2}$ (20 psi) in the presence of $\mathbf{1}\left(1.7 \times 10^{-3} \mu \mathrm{mol}\right)$ in water $(3 \mathrm{~mL})$ was stirred at $110^{\circ} \mathrm{C}$. The initial turnover frequency (TOF) of $5100 \mathrm{~h}^{-1}$ after 30 min and the turnover number (TON) of 25500 after $18 \mathrm{~h}$ were obtained as measured by both GC and NMR spectroscopic methods. The etherification reaction under neat conditions led to a considerably higher activity for $\mathbf{2 a}$ (TOF $=7600 \mathrm{~h}^{-1}$ and TON = 32000). The salient feature of the catalytic method is that it employs cheaply available $\mathrm{H}_{2}$ as the reducing agent in an aqueous solution.

Substrate scope of the etherification reaction was explored by using the catalyst $\mathbf{1}$ (Table 1 ). Both aliphatic and aryl-substituted aldehydes readily reacted with both primary and secondary alcohols to form the ether products 2 (entries 1-13). In the case of 1,2hexanediol, exclusive etherification to the primary alcohol was observed in yielding the ether product $\mathbf{2} \mathbf{i}$ (entry 9). The coupling between aliphatic alcohol and aldehyde substrates was sluggish, leading to a lower yield than with benzylic ones (entries 12 and 13). In this case, extending the reaction time to $24 \mathrm{~h}$ did not increase the product yield significantly.

The etherification of ketones also proceeded smoothly to give the a-substituted ether products. The aryl-substituted ketones with both primary and secondary alcohols led to the corresponding ether products $\mathbf{2 n - x}$ (entries 14-24). The coupling with a linear aliphatic ketone was found to be considerably slower than with benzylic ketones (entry 25). The treatment of a chiral alcohol with 4methoxyacetophenone led to a 1:1 diastereomeric mixture of ether product $\mathbf{2 z}$ (entry 26 ). In most cases, using 2 equiv of alcohol substrate (second equivalent alcohol is served as the hydrogen donor) was found to be convenient for forming the ether products, but 1 equiv of alcohol substrate can be used with $\mathrm{H}_{2}$ (1-2 atm) without sacrificing the product yields. In addition, a $1: 1$ toluene $/ \mathrm{H}_{2} \mathrm{O}$ was used as the solvent system in most cases, and pure water was used for watersoluble substrates. The catalytic method achieves a highly 
NOT THE PUBLISHED VERSION; this is the author's final, peer-reviewed manuscript. The published version may be accessed by following the link in the citation at the bottom of the page.

chemoselective etherification of aldehydes and ketones without using any reactive reagents, and employs environmentally sustainable and cheaply available alcohol substrates.

Table 1. Etherification of Alcohols with Aldehydes and Ketones ${ }^{a}$ entry carbonyl compd ulcohol product(s) time (h) yield (\%)

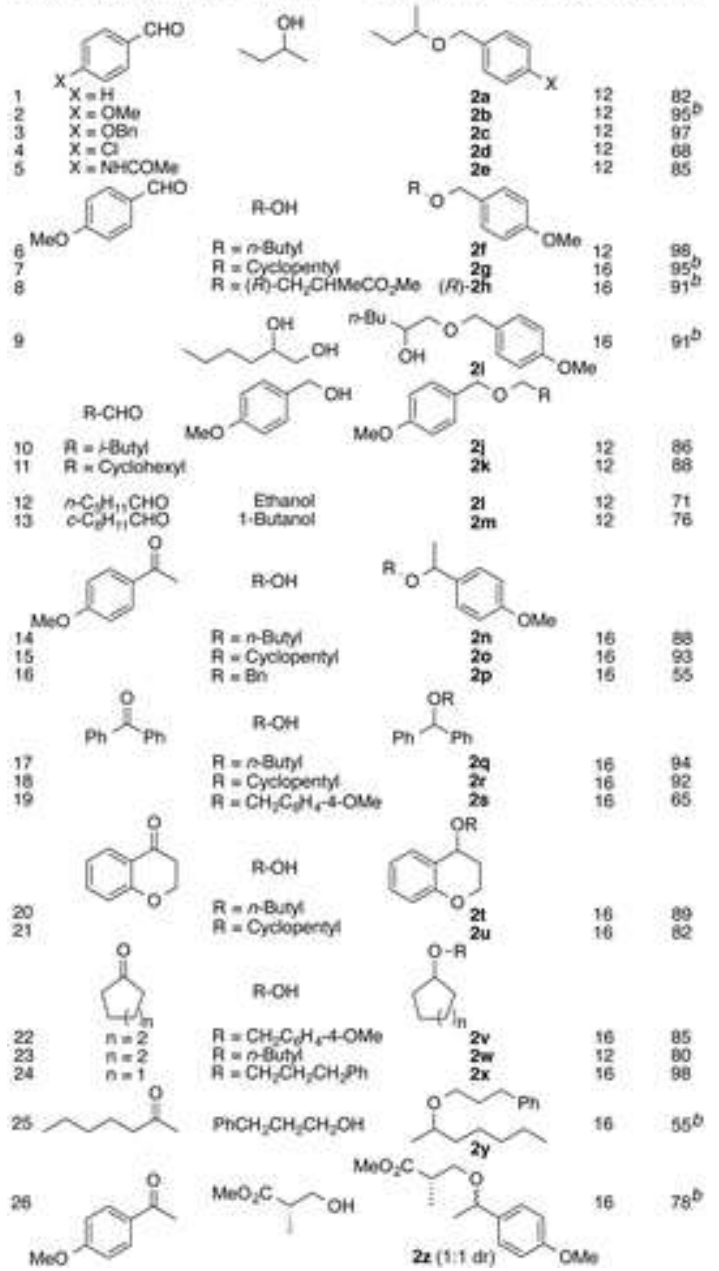

Table aReaction conditions: carbonyl compound $(1.0 \mathrm{mmol})$, alcohol $(2.0 \mathrm{mmol})$, toluene $/ \mathrm{H}_{2} \mathrm{O}(\mathrm{v} / \mathrm{v}=1: 1,3 \mathrm{~mL}), \mathbf{1}(3 \mathrm{~mol} \%), 110^{\circ} \mathrm{C}$.

Table bReaction in pure water $(3 \mathrm{~mL})$.

To further illustrate the synthetic versatility of the catalytic method, we next surveyed the etherification reaction of functionalized alcohol substrates of biological importance (Figure 1). The etherification of $(-)$-menthol and $2^{\prime}, 3^{\prime}$-isopropylidenedeoxyuridine with 4-methoxybenzaldehyde smoothly formed the ether product 3a and $\mathbf{3 b}$ without any epimerization or side products. The etherification reaction of an amino acid and steroid derivatives with 4-

Organic Letters, Vol 17, No. 7 (2015): pg. 1778-1781. DOI. This article is @ American Chemical Society and permission has been granted for this version to appear in e-Publications@Marquette. American Chemical Society does not grant permission for this article to be further copied/distributed or hosted elsewhere without the express permission from American Chemical Society. 
methoxybenzaldehyde also proceeded predictively to give the products 3c-e, while displaying high chemoselectivity toward the ether product formation. An aliphatic aldehyde was successfully used for fenofibrate and chloroamphenicol, where in the latter case, a selective etherification to the primary alcohol was achieved over the secondary one in forming the ether product $\mathbf{3 h}$. In these cases, a nonprotic solvent chlorobenzene was found to be most suitable for the coupling reaction, as the substrates become insoluble in toluene $/ \mathrm{H}_{2} \mathrm{O}$ solvent. The structure of $\mathbf{3 e}$ was determined by $\mathrm{X}$-ray crystallography (Figure S6, SI).<smiles>COc1ccc(CO[C@H]2C[C@H](C)CC[C@H]2C(C)C)cc1</smiles><smiles>COc1ccc(COC[C@H]2O[C@@H](n3ccc(=O)[nH]c3=O)[C@H]3OC(C)(C)O[C@@H]32)cc1</smiles>

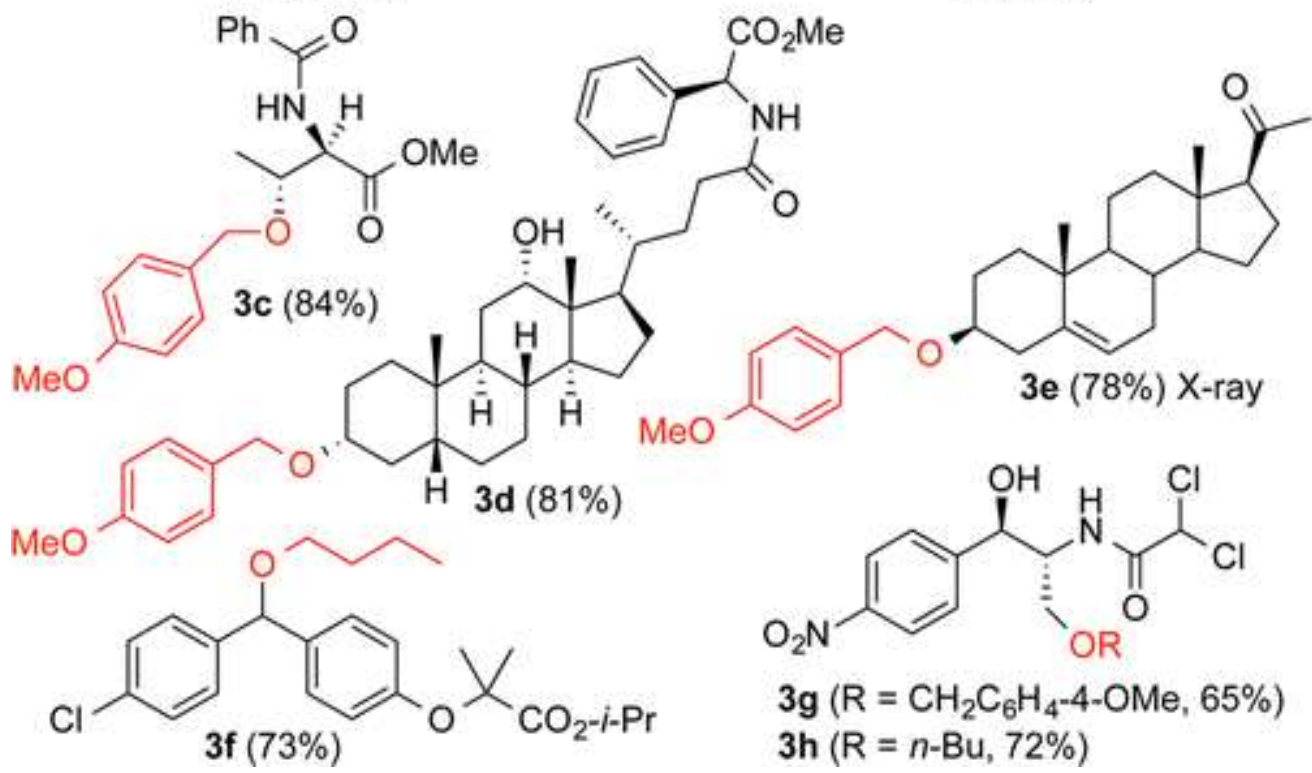

Figure 1. Etherification biologically active alcohols with aldehydes. Reaction conditions: alcohol $(1.0 \mathrm{mmol})$, aldehyde $(1.0 \mathrm{mmol}), \mathrm{H}_{2}(1 \mathrm{~atm}), \mathrm{C}_{6} \mathrm{H}_{5} \mathrm{Cl}(2 \mathrm{~mL}), \mathbf{1}(3$ $\mathrm{mol} \%), 110^{\circ} \mathrm{C}$.

A series of kinetic experiments were performed to gain mechanistic insights for the etherification reaction. First, the $H / D$ exchange pattern on the coupling reaction was examined. The treatment of 4-methoxybenzaldehyde with 1 -butanol (2 equiv) in $\mathrm{D}_{2} \mathrm{O}$ led to the selective deuterium incorporation to benzylic position of the product $2 f$ (Scheme 1). Conversely, 4-methoxybenzaldehyde with 2-

Organic Letters, Vol 17, No. 7 (2015): pg. 1778-1781. DOI. This article is @ American Chemical Society and permission has been granted for this version to appear in e-Publications@Marquette. American Chemical Society does not grant permission for this article to be further copied/distributed or hosted elsewhere without the express permission from American Chemical Society. 
propanol- $d_{8}$ (2 equiv) in $\mathrm{H}_{2} \mathrm{O}$ gave the product with $\sim 50 \%$ of deuterium on the benzylic position. In a control experiment, the treatment of 2-propanol with $\mathrm{D}_{2} \mathrm{O}$ in the presence of $\mathbf{1}(2 \mathrm{~mol} \%$ ) led to a rapid $\mathrm{H} / \mathrm{D}$ exchange to form $\left(\mathrm{CH}_{3}\right)_{2} \mathrm{CHOD}$ at room temperature. These results suggest that an extensive H/D exchange between the solvent molecules and the alcohol substrate led to the deuterium incorporation to the benzylic position of the ether product during the $\mathrm{C}=\mathrm{O}$ hydrogenolysis step.

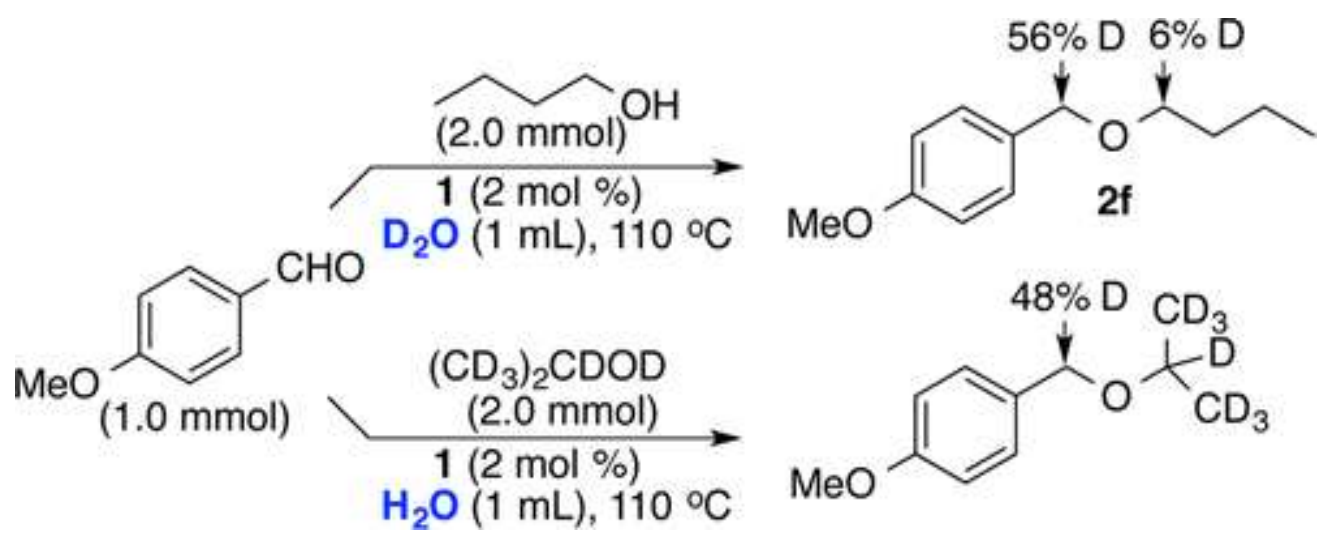

Scheme 1

To probe the involvement of solvent molecules, the solvent isotope effect was measured on the catalytic reaction. The initial rates of the reaction between 4-methoxybenzaldehyde with 2-butanol ( 2 equiv) were separately measured in $\mathrm{H}_{2} \mathrm{O}$ and $\mathrm{D}_{2} \mathrm{O}$. The first order plots showed a relatively high normal isotope effect of $k_{\mathrm{H} 2 \mathrm{O}} / k_{\mathrm{D} 2 \mathrm{O}}=2.9 \pm 0.2$ (Figure 2). A similar solvent isotope effect was obtained from 2propanol/2-propanol- $d_{8}\left(k_{\mathrm{PrOH}} / k_{\mathrm{PrOD}}=2.0 \pm 0.2\right.$, Figure S3, SI $) . A$ relatively large solvent isotope effect suggests that the water molecules are intricately involved in $\mathrm{C}-\mathrm{O}$ bond cleavage and hydrogenolysis steps via extensive hydrogen-bonding-network interactions. ${ }^{10}$ 
NOT THE PUBLISHED VERSION; this is the author's final, peer-reviewed manuscript. The published version may be accessed by following the link in the citation at the bottom of the page.

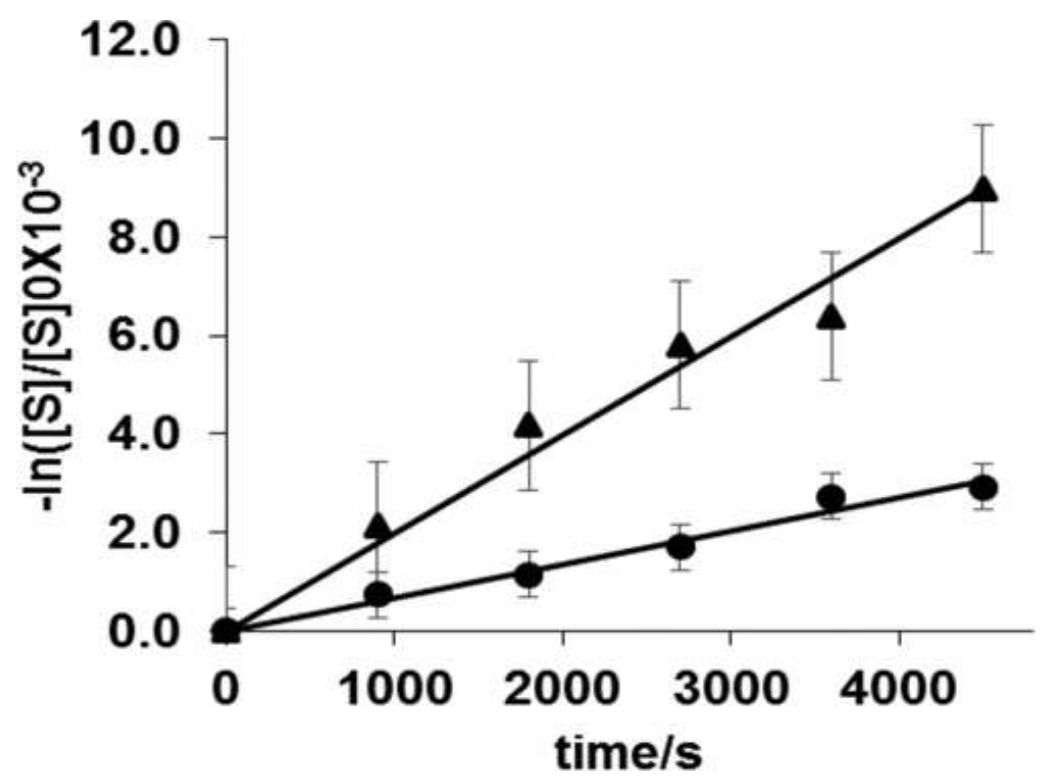

Figure 2. First-order plot of the 4-methoxybenzaldehyde (S) with 2-butanol in $\mathrm{H}_{2} \mathrm{O}$ $(\boldsymbol{\Delta})$ and in $\mathrm{D}_{2} \mathrm{O}(\bullet)$.

To probe the electronic effect on the aldehyde substrate, we constructed a Hammett plot from measuring the rate of a series of para-substituted benzaldehydes $p-\mathrm{X}-\mathrm{C}_{6} \mathrm{H}_{4} \mathrm{CHO}(\mathrm{X}=\mathrm{OMe}, \mathrm{Me}, \mathrm{H}, \mathrm{F}, \mathrm{Cl})$ with 2-butanol. A linear correlation from the relative rate vs Hammett $\sigma_{p}$ led to a negative $\rho$ value of $-1.6 \pm 0.1$ (Figure 3 ). The result is consistent with the notion that an electron-releasing group promotes the $\mathrm{C}-\mathrm{O}$ bond hydrogenolysis step but not during the formation of hemiacetal species. Similar Hammett $\rho$ values have been observed in the catalytic coupling reactions of arenes. ${ }^{11}$

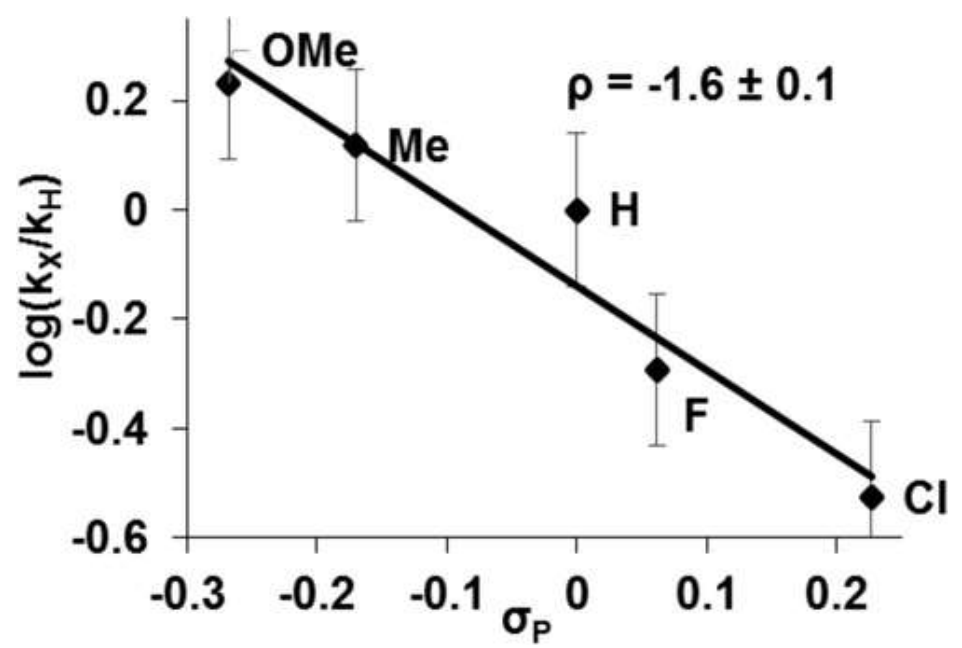

Figure 3. Hammett plot from the reaction of $p-\mathrm{XC}_{6} \mathrm{H}_{4} \mathrm{CHO}(\mathrm{X}=\mathrm{OMe}, \mathrm{Me}, \mathrm{H}, \mathrm{F}, \mathrm{Cl})$ with 2-butanol.

Organic Letters, Vol 17, No. 7 (2015): pg. 1778-1781. DOI. This article is @ American Chemical Society and permission has been granted for this version to appear in e-Publications@Marquette. American Chemical Society does not grant permission for this article to be further copied/distributed or hosted elsewhere without the express permission from American Chemical Society. 
To discern the structure of catalytically relevant species, we explored the reactions of $\mathbf{1}$ with alcohols and water. The treatment of the complex $1(0.07 \mathrm{mmol})$ with excess 1 -butanol $(0.7 \mathrm{mmol})$ in $\mathrm{CD}_{2} \mathrm{Cl}_{2}(0.6 \mathrm{~mL})$ led to the formation of a new $\mathrm{Ru}-\mathrm{H}$ species within 30 min at room temperature (Scheme 2). The appearance of a new set of peaks was observed along with the formation of free benzene molecule as monitored by NMR $\left({ }^{1} \mathrm{H}\right.$ NMR: $\delta-18.8\left(\mathrm{~d}, J_{\mathrm{PH}}=31.3 \mathrm{~Hz}\right) \mathrm{ppm}$; ${ }^{31} \mathrm{P}\left\{{ }^{1} \mathrm{H}\right\}$ NMR: $\left.\delta 76.0 \mathrm{ppm}\right)$. We tentatively assign the new species to the alcohol-coordinated complex $\left[(1 \text {-butanol })_{3}\left(\mathrm{PCy}_{3}\right)(\mathrm{CO}) \mathrm{RuH}^{+} \mathrm{BF}_{4}{ }^{-}\right.$ (4a), in light of the previously observed arene exchange reaction of 1. ${ }^{12}$ The analogous reaction with excess water also formed the watercoordinated complex 4b $\left({ }^{1} \mathrm{H}\right.$ NMR: $\delta-17.7\left(\mathrm{~d}, J_{\mathrm{PH}}=30.3 \mathrm{~Hz}\right) \mathrm{ppm}$; ${ }^{31} \mathrm{P}\left\{{ }^{1} \mathrm{H}\right\}$ NMR: $\left.\delta 73.0 \mathrm{ppm}\right)$, which steadily decomposed within $1 \mathrm{~h}$ at room temperature. The catalytic activity of complex $\mathbf{4 a}$ was found to be identical to $\mathbf{1}$ for the etherification of 4 -methoxybenzaldehyde with 2-butanol under the conditions described in eq 1.

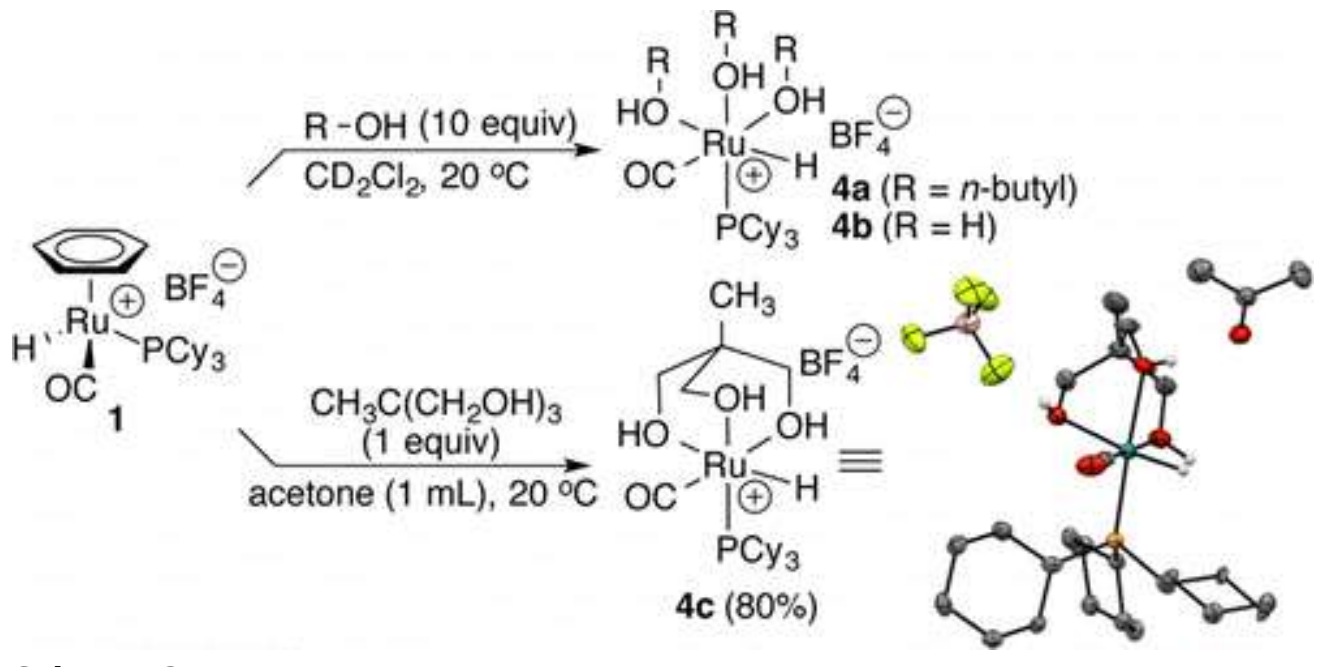

Scheme 2

We next examined the reaction of complex $\mathbf{1}$ with diols and triols as a way to form a stable alcohol-coordinated complex. Thus, the treatment of $\mathbf{1}$ with 1,1,1-tris(hydroxymethyl)ethane in acetone at room temperature led to the triol-coordinated complex 4c, which was isolated in $80 \%$ after recrystallization in acetone/pentane. The X-ray crystal structure of 4c showed a distorted octahedral geometry with a facial arrangement between the triol and the ancillary ligands. A number of ruthenium-hydride complexes have been successfully utilized as catalysts for the alcohol-coupling reactions. ${ }^{13}$

Organic Letters, Vol 17, No. 7 (2015): pg. 1778-1781. DOI. This article is @ American Chemical Society and permission has been granted for this version to appear in e-Publications@Marquette. American Chemical Society does not grant permission for this article to be further copied/distributed or hosted elsewhere without the express permission from American Chemical Society. 


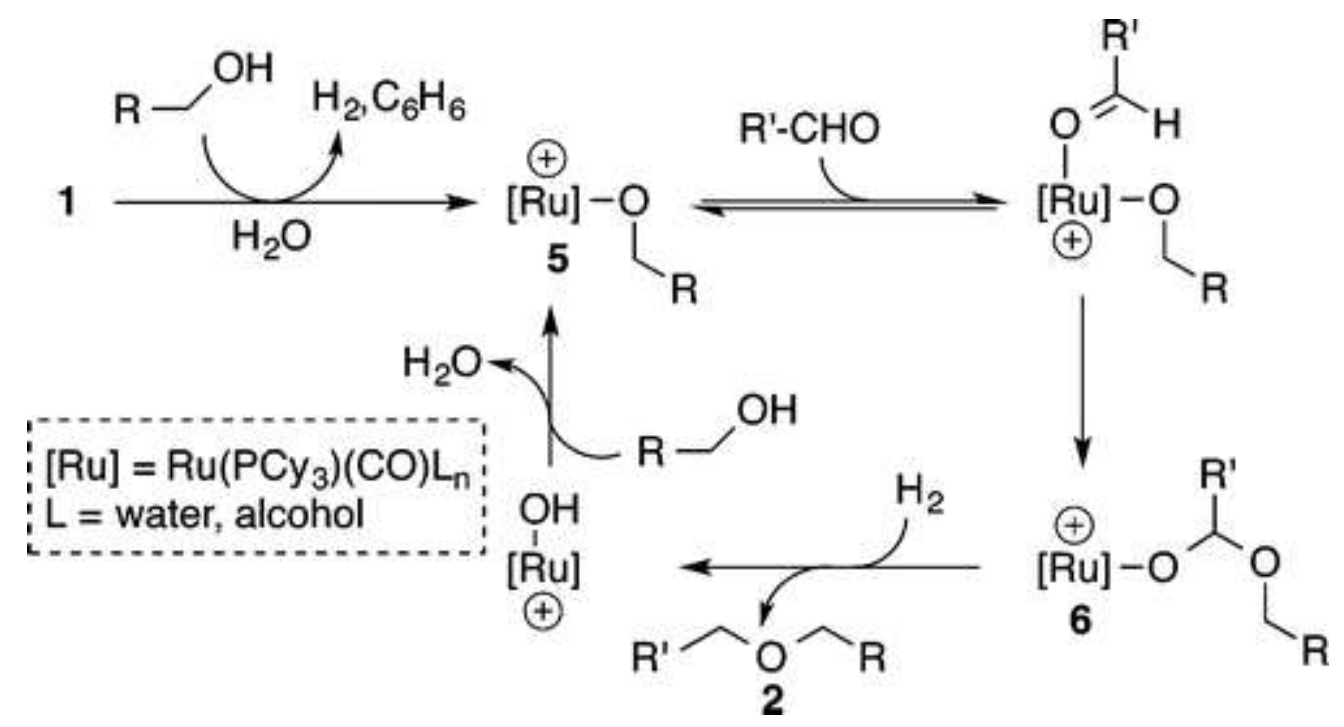

Scheme 3. Possible Mechanism for the Reductive Etherification of an Alcohol with an Aldehyde

We present a possible mechanism of the catalytic reaction on the basis of these results (Scheme 3 ). We propose that an unsaturated cationic Ru-alkoxy (or Ru-alcohol) species $\mathbf{5}$ is initially generated from the benzene ligand displacement and the dehydrogenation steps. In support of this notion, we have been able to detect/isolate the formation of alcohol-coordinated cationic Ru-H complex 4 from the reaction of $\mathbf{1}$ with alcohols and water. The coordination of a carbonyl substrate followed by the nucleophilic addition of an alkoxy group is envisioned for the formation of hemiacetoxy species $\mathbf{6}$. The observed $H / D$ exchange pattern on the a-carbon of the ether product $\mathbf{2}$ as well as a normal solvent isotope effect indicates that the solvent molecules are intricately involved in the $\mathrm{C}-\mathrm{O}$ bond hydrogenolysis step. The Hammett correlation study, where the reaction is promoted by electron-releasing group of the aldehyde, supports the notion that the hydrogenolysis step is likely the turnover-limiting step of the catalytic reaction. ${ }^{14}$

In conclusion, we successfully developed a highly chemoselective catalytic etherification method of aldehydes and ketones with alcohols. The ruthenium hydride catalyst exhibits a uniquely high activity as well as broad substrate scope in promoting the reductive etherification reaction of carbonyl compounds in an aqueous solution without using any reactive reagents or forming 
NOT THE PUBLISHED VERSION; this is the author's final, peer-reviewed manuscript. The published version may be accessed by following the link in the citation at the bottom of the page.

wasteful byproducts. We anticipate that the catalytic etherification method provides an environmentally sustainable and cost-effective protocol for forming unsymmetrical ether compounds.

The authors declare no competing financial interest.

\section{Acknowledgment}

Financial support from the National Science of Foundation (CHE-1358439) and National Institute of Health General Medical Sciences (R15 GM109273) is gratefully acknowledged. We thank Dr. Sergey Lindeman (Marquette University) for the X-ray crystal structure determination of $\mathbf{3 e}$ and $\mathbf{4 c}$.

\section{References}

${ }^{1}$ Reviews:(a) Mitsunobu, O. In Comprehensive Organic Synthesis; Trost, B. M., Fleming, J., Eds.; Pergamon Press: New York, 1991; Vol. 6, pp 131. (b) Lee, C.; Matunas, R. In Comprehensive Organometallic Chemistry III; Crabtree, R. H., Mingos, D. M., Eds.; Elsevier: Boston, 2007; Vol. 10, pp 649- 693.

2 (a) Olah, G. A.; Molnár, A. Hydrocarbon Chemistry, 2nd ed.; Wiley: Hoboken, NJ, 2003. (b) Klier, K.; Beretta, A.; Sun, Q.; Feeley, O. C.; Herman, R. G. Catal. Today 1997, 36, 3- 14. (c) Nowak, I.; Ziolek, M. Chem. Rev. 1999, 99, 3603- 3624. (d) Tanabea, K.; Hölderich, W. F. Appl. Catal., A 1999, 181, 399- 434

3 (a) Smith, M. B.; March, J. March's Advanced Organic Chemistry, 5th ed.; Wiley: New York, 2001. (b) Baggett, N. In Comprehensive Organic Synthesis; Barton, D.; Ollins, W. D., Eds.; Pergaman: Oxford, 1979; Vol. 1.

4 (a) Ley, S. V.; Thomas, A. W. Angew. Chem., Int. Ed. 2003, 42, 54005449. (b) Ma, D.; Cai, Q. Acc. Chem. Res. 2008, 41, 1450- 1460. (c) Swamy, K. C. K.; Kumar, N. N. B.; Balaraman, E.; Kumar, K. V. P. P. Chem. Rev. 2009, 109, 2551- 2651

${ }^{5}$ (a) Sassaman, M. B.; Kotian, K. D.; Prakash, G. K. S.; Olah, G. A. J. Org. Chem. 1987, 52, 4314- 4319. (b) Sakai, N.; Moriya, T.; Konakahara, T. J. Org. Chem. 2007, 72, 5920- 5922. (c) Haibach, M. C.; Guan, C.; Wang, D. Y.; Li, B.; Lease, N.; Steffens, A. M.; Krogh-Jespersen, K. ; Goldman, A. S. J. Am. Chem. Soc. 2013, 135, 15062- 15070

${ }^{6}$ (a) Wang, X.; Lu, Y.; Dai, H.-X.; Yu, J.-Q. J. Am. Chem. Soc. 2010, 132, 12203-12205. (b) Jiang, T.-S.; Wang, G.-W. J. Org. Chem. 2012, 77, 9504- 9509. (c) Li, W.; Sun, P. J. Org. Chem. 2012, 77, 8362- 8366. (d) Zhang, S.-Y.; He, G.; Zhao, Y.; Wright, K.; Nack, W. A.; Chen, G. J. Am. Chem. Soc. 2012, 134, 7313- 7316. (e) Chen, F.-J.; Zhao, S.; 
NOT THE PUBLISHED VERSION; this is the author's final, peer-reviewed manuscript. The published version may be accessed by following the link in the citation at the bottom of the page.

Hu, F.; Chen, K.; Zhang, Q.; Zhang, S.-Q.; Shi, B.-F. Chem. Sci. 2013, 4, 4187-4192. (f) Roane, J.; Daugulis, O. Org. Lett. 2013, 15, 58425845

7 (a) Lee, S. H.; Park, Y. J.; Yoon, C. M. Tetrahedron Lett. 1999, 40, 60496050. (b) Evans, P. A.; Cui, J.; Gharpure, S. J.; Hinkle, R. J. J. Am. Chem. Soc. 2003, 125, 11456- 11457. (c) Yang, W.-C.; Lu, X.-A.; Kulkarni, S. S.; Hung, S.-C. Tetrahedron Lett. 2003, 44, 7837- 7840. (d) Iwanami, K.; Seo, H.; Tobita, Y.; Oniyama, T. Synthesis 2005, 183- 186. (e) Barluenga, J.; Tomás-Gamasa, M.; Aznar, F.; Valdøs, C. Angew. Chem., Int. Ed. 2010, 49, 4993- 4996. (f) Gharpure, S. J.; Prasad, J. V. K. J. Org. Chem. 2011, 76, 10325- 10331

8 (a) Min, B. K.; Friend, C. M. Chem. Rev. 2007, 107, 2709- 2724. (b) Sheldon, R. A. Chem. Commun. 2008, 3352- 3365. (c) Li, C.-J.; Trost, B. M. Proc. Natl. Acad. Sci. U.S.A. 2008, 105, 13197- 13202

${ }^{9}$ Kim, J.; Lee, D.-H.; Kalutharage, N.; Yi, C. S. ACS Catal. 2014, 4, 38813885

10 Selected recent examples: (a) Gómez-Gallego, M.; Sierra, M. A. Chem. Rev. 2011, 111, 4857- 4963. (b) Gregory, M. C.; Denisov, I. G.; Grinkova, Y. G.; Khatri, Y.; Sligar, S. G. J. Am. Chem. Soc. 2013, 135, 16245- 16247. (c) Waugh, M. W.; Marsh, E. N. G. Biochemistry 2014, $53,5537-5543$

11 (a) Nakagawa, Y.; Mizuno, N. Inorg. Chem. 2007, 46, 1727- 1736. (b) Fedorov, A.; Chen, P. Organometallics 2010, 29, 2994- 3000. (c) Chakraborty, S.; Blacque, O.; Fox, T.; Berke, H. ACS Catal. 2013, 3, 2208- 2217. (d) Ball, L. T.; Lloyd-Jones, G. C.; Russell, C. A. J. Am. Chem. Soc. 2014, 136, 254- 264

12 (a) Kwon, K.-H.; Lee, D. W.; Yi, C. S. Organometallics 2010, 29, 57485760. (b) Lee, H.; Yi, C. S. Eur. J. Org. Chem. 2015, 1899- 1904

13 (a) Sieffert, N.; Bühl, M. J. Am. Chem. Soc. 2010, 132, 8056- 8070. (b) Denichoux, A.; Fukuyama, T.; Doi, T.; Horiguchi, J.; Ryu, I. Org. Lett. 2010, 12, 1- 3. (c) Fogler, E.; Balaraman, E.; Ben-David, Y.; Leitus, G.; Shimon, L. J. W.; Milstein, D. Organometallics 2011, 30, 38263833. (d) Kang, B.; Fu, Z.; Hong, S. H. J. Am. Chem. Soc. 2013, 135, 11704- 11707. (e) Tseng, K.-N. T.; Kampf, J. W.; Szymczak, N. K. Organometallics 2013, 32, 2046- 2049. (f) Pingen, D.; Lutz, M.; Vogt, D. Organometallics 2014, 33, 1623- 1629

${ }^{14}$ In light of the recent results as described in ref 9 , we have considered an alternative mechanism involving the hydrogenation of carbonyl substrate to the corresponding alcohol and the subsequent dehydrative coupling with the second alcohol substrate. Since both mechanistic pathways should involve an alcohol-ketone hydrogenationdehydrogenation redox process and a $\mathrm{C}-\mathrm{O}$ bond hydrogenolysis step,

Organic Letters, Vol 17, No. 7 (2015): pg. 1778-1781. DOI. This article is (C) American Chemical Society and permission has been granted for this version to appear in e-Publications@Marquette. American Chemical Society does not grant permission for this article to be further copied/distributed or hosted elsewhere without the express permission from American Chemical Society. 
NOT THE PUBLISHED VERSION; this is the author's final, peer-reviewed manuscript. The published version may be accessed by following the link in the citation at the bottom of the page.

we cannot distinguish between these two pathways at the present time.

\section{Supporting Information}

Experimental procedures and methods, characterization and NMR spectra, and X-ray data of $\mathbf{3 e}$ and $\mathbf{4 c}$ (CIF). This material is available free of charge via the Internet at http://pubs.acs.org.

Organic Letters, Vol 17, No. 7 (2015): pg. 1778-1781. DOI. This article is (C American Chemical Society and permission has been granted for this version to appear in e-Publications@Marquette. American Chemical Society does not grant permission for this article to be further copied/distributed or hosted elsewhere without the express permission from American Chemical Society. 


\title{
Supporting Information
}

Chemoselective Formation of Unsymmetrically Substituted Ethers from Catalytic Reductive Coupling of Aldehydes and Ketones with Alcohols in Aqueous Solution

\author{
Nishantha Kalutharage and Chae S. Yi* \\ Department of Chemistry, Marquette University, Milwaukee, Wisconsin 53201-1881 United States
}

\section{Table of Contents}

$\begin{array}{ll}\text { 1. General Information } & \text { S2 }\end{array}$

$\begin{array}{ll}\text { 2. Experimental Procedures (Table S1) } & \text { S2 }\end{array}$

$\begin{array}{ll}\text { 3. Hammett Study (Figure S1) S3 } & \text { S3 }\end{array}$

4. Solvent Isotope Effect Study (Figures S2 and S3)

5. H/D Exchange Reaction of 3-Methoxybenzaldehyde with 1-Butanol in $\mathrm{D}_{2} \mathrm{O}$ (Figure S4) S5

6. Detection and Synthesis of the Alcohol Complexes 4a-4c (Figure S5) S6

7. X-Ray Crystallographic Determination of 3e and 4c (Figures S6 and S7) S7

$\begin{array}{ll}\text { 8. Characterization Data of the Products } & \text { S9 }\end{array}$

9. ${ }^{1} \mathrm{H}$ and ${ }^{13} \mathrm{C}$ NMR Spectra of the Products $\quad$ S17

10. X-Ray Crystallographic Data of 3e and 4c (Tables S8-S23) S35 
1. General Information. All operations were carried out in a nitrogen-filled glove box or by using standard high vacuum and Schlenk techniques unless otherwise noted. Solvents were freshly distilled over the appropriate drying reagents. Tetrahydrofuran, benzene, toluene, hexanes and dioxane were distilled from purple solutions of sodium and benzophenone immediately prior to use. Dichloromethane and chlorobenzene $\left(\mathrm{C}_{6} \mathrm{H}_{5} \mathrm{Cl}\right)$ were dried over calcium hydride. The ${ }^{1} \mathrm{H},{ }^{2} \mathrm{H},{ }^{13} \mathrm{C}$ and ${ }^{31} \mathrm{P}$ NMR spectra were recorded on a Varian 300 or 400 MHz FT-NMR spectrometer, and the data are reported as: $\mathrm{s}=$ singlet, $\mathrm{d}=$ doublet, $\mathrm{t}=$ triplet, $\mathrm{q}=$ quartet, $\mathrm{p}=$ pentet, $\mathrm{m}=$ multiplet, $\mathrm{br}=$ broad, app = apparent; coupling constant(s) in Hz; integration. Mass spectra were recorded from a Agilent 6850 GC-MS spectrometer with a HP-5 (5\% phenylmethylpolysiloxane) column (30 $\mathrm{m}, 0.32 \mathrm{~mm}, 0.25 \mu \mathrm{m})$. The conversion of organic products was measured from a Hewlett-Packard HP $6890 \mathrm{GC}$ spectrometer. High resolution mass spectra were obtained at the Center of Mass Spectrometry, Washington University, St. Louis, MO and at the Mass Spectrometry/ICP Lab, Department of Chemistry and Biochemistry, University of Wisconsin-Milwaukee, Milwaukee, WI. Elemental analyses were performed at the Midwest Microlab, Indianapolis, IN.

\section{Experimental Procedures}

General Procedure for the Catalytic Reaction. Method A: In a glove box, complex 1 (17 mg, $3 \mathrm{~mol} \%$ ), carbonyl compound $(1.0 \mathrm{mmol})$ and an alcohol $(2.5 \mathrm{mmol})$ were dissolved in $\mathrm{C}_{6} \mathrm{H}_{5} \mathrm{Cl}(1 \mathrm{~mL})$ in a $25 \mathrm{~mL}$ Schlenk tube equipped with a Teflon stopcock and a magnetic stirring bar. The tube was brought out of the box, and was stirred for $8-16 \mathrm{~h}$ in an oil bath which was preset at $110{ }^{\circ} \mathrm{C}$. The reaction tube was taken out of the oil bath, and was cooled to room temperature. After the tube was open to air, the solution was filtered through a short silica gel column $\left(\mathrm{CH}_{2} \mathrm{Cl}_{2}\right)$, and the filtrate was analyzed by GC and GC-MS. Analytically pure product was isolated by a simple column chromatography on silica gel (280-400 mesh, hexanes/Et ${ }_{2} \mathrm{O}$ or hexanes/EtOAc).

Method B: In a glove box, complex 1 (17 mg, $3 \mathrm{~mol} \%)$, a carbonyl compound (1.0 mmol) and an alcohol (1.3 mmol) were added into a $25 \mathrm{~mL}$ Schlenk tube equipped with a Teflon stopcock and a magnetic stirring bar. The tube was brought out of the box, and $\mathrm{H}_{2} \mathrm{O}(1 \mathrm{~mL})$ was added $(0.5 \mathrm{~mL}$ of toluene for water insoluble substrates). The tube was evacuated, filled with $\mathrm{H}_{2}(1 \mathrm{~atm})$, and was stirred for $8-16 \mathrm{~h}$ in an oil bath which was preset at $110^{\circ} \mathrm{C}$. The reaction tube was taken out of the oil bath, and was cooled to room temperature. After the tube was open to air, the solution was filtered through a short silica gel column $\left(\mathrm{CH}_{2} \mathrm{Cl}_{2}\right)$, and the filtrate was analyzed by GC and GC-MS. Analytically pure product was isolated by a simple column chromatography on silica gel (280-400 mesh, hexanes/Et ${ }_{2} \mathrm{O}$ or hexanes/EtOAc).

Catalyst Screening. In a glove box, 4-methoxybenzaldehyde (136 mg, $1.0 \mathrm{mmol})$, 1-butanol (185 mg, 2.5 mmol) and a catalyst $(2 \mathrm{~mol} \%)$ were dissolved in toluene $/ \mathrm{H}_{2} \mathrm{O}(1: 1,1 \mathrm{~mL})$ in a $25 \mathrm{~mL}$ Schlenk tube equipped with a Teflon stopcock and a magnetic stirring bar. The tube was brought out of the box, and was stirred for 12 
$\mathrm{h}$ in an oil bath which was preset at $110^{\circ} \mathrm{C}$. The reaction tube was taken out of the oil bath and the solution mixture was analyzed by GC and GC-MS. The results are summarized in Table S1.

Determination of TON. In a glove box, 4-methoxybenzaldehyde (2.72 g, $20 \mathrm{mmol})$, 2-butanol (1.48 g, 23 $\mathrm{mmol})$ and the ruthenium catalyst $1\left(0.2 \mu \mathrm{g}, 1.7 \times 10^{-3}\right.$ mol \%) were dissolved in water $(3 \mathrm{~mL})$ in a $100 \mathrm{~mL}$ Fisher-Porter pressure tube. The reaction tube was brought out of the box, and $\mathrm{H}_{2}(20 \mathrm{psi})$ was added. The tube was stirred in an oil bath at $110^{\circ} \mathrm{C}$. A small aliquot was drwan from the reaction mixture after $1 \mathrm{~h}$ and after $18 \mathrm{~h}$, and was analyzed by GC and NMR spectroscopic methods.

Table S1. Catalyst Survey for the Coupling Reaction of 4-Methoxybenzaldehyde with 1-Butanol. ${ }^{a}$

\begin{tabular}{|c|c|c|c|}
\hline entry & catalyst & additive & yield $(\%)$ \\
\hline 1 & {$\left[\left(\mathrm{C}_{6} \mathrm{H}_{6}\right)\left(\mathrm{PC}_{3}\right)(\mathrm{CO}) \mathrm{RuH}\right]^{+} \mathrm{BF}_{4}^{-}(1)$} & & 95 \\
\hline 2 & {$\left[\mathrm{RuH}(\mathrm{CO})\left(\mathrm{PCy}_{3}\right)\right]_{4}(\mathrm{O})(\mathrm{OH})_{2}$} & & 0 \\
\hline 3 & {$\left[\mathrm{RuH}(\mathrm{CO})\left(\mathrm{PCy}_{3}\right)\right]_{4}(\mathrm{O})(\mathrm{OH})_{2}$} & $\mathrm{HBF}_{4} \cdot \mathrm{OEt}_{2}$ & 72 \\
\hline 4 & $\mathrm{RuCl}_{3} \cdot 3 \mathrm{H}_{2} \mathrm{O}$ & $\mathrm{HBF}_{4} \cdot \mathrm{OEt}_{2}$ & 0 \\
\hline 5 & $\mathrm{RuCl}_{2}\left(\mathrm{PPh}_{3}\right)_{3}$ & $\mathrm{HBF}_{4} \cdot \mathrm{OEt}_{2}$ & trace \\
\hline 6 & $\mathrm{RuH}_{2}(\mathrm{CO})\left(\mathrm{PPh}_{3}\right)_{3}$ & & 3 \\
\hline 7 & $\mathrm{RuH}_{2}(\mathrm{CO})\left(\mathrm{PPh}_{3}\right)_{3}$ & $\mathrm{HBF}_{4} \cdot \mathrm{OEt}_{2}$ & 10 \\
\hline 8 & {$\left[\mathrm{RuCl}_{2}(\mathrm{COD})\right]_{x}$} & $\mathrm{HBF}_{4} \cdot \mathrm{OEt}_{2}$ & 0 \\
\hline 9 & {$\left[\mathrm{RuH}(\mathrm{CO})\left(\mathrm{PCy}_{3}\right)_{2}\left(\mathrm{CH}_{3} \mathrm{CN}\right)_{2}\right]^{+} \mathrm{BF}_{4}^{-}$} & & 20 \\
\hline 10 & {$\left[(\mathrm{COD}) \mathrm{RuCl}_{2}\right]_{\mathrm{x}}$} & $\mathrm{HBF}_{4} \cdot \mathrm{OEt}_{2}$ & 0 \\
\hline 11 & $\mathrm{Ru}_{3}(\mathrm{CO})_{12}$ & $\mathrm{NH}_{4} \mathrm{PF}_{6}$ & 0 \\
\hline 12 & $\mathrm{Cy}_{3} \mathrm{PH}^{+} \mathrm{BF}_{4}^{-}$ & & trace \\
\hline 13 & $\mathrm{BF}_{3} \cdot \mathrm{OEt}_{2}$ & & trace \\
\hline 14 & $\mathrm{AlCl}_{3}$ & & 7 \\
\hline 15 & $\mathrm{FeCl}_{3} \cdot \mathrm{H}_{2} \mathrm{O}$ & & trace \\
\hline 16 & $\mathrm{HBF}_{4} \cdot \mathrm{OEt}_{2}$ & & 6 \\
\hline 17 & $\mathrm{CF}_{3} \mathrm{SO}_{3} \mathrm{H}$ & & trace \\
\hline
\end{tabular}

${ }^{a}$ Reaction conditions: 4-methoxybenzaldehyde (1.0 mmol), 1-butanol (2.5 mmol), catalyst (2 mol \%), additive (1.0 equiv to catalyst), toluene $/ \mathrm{H}_{2} \mathrm{O}(1 \mathrm{~mL}, 1: 1), 12 \mathrm{~h}, 110{ }^{\circ} \mathrm{C}$. The product yield was determined by $\mathrm{GC}$ and GC-MS.

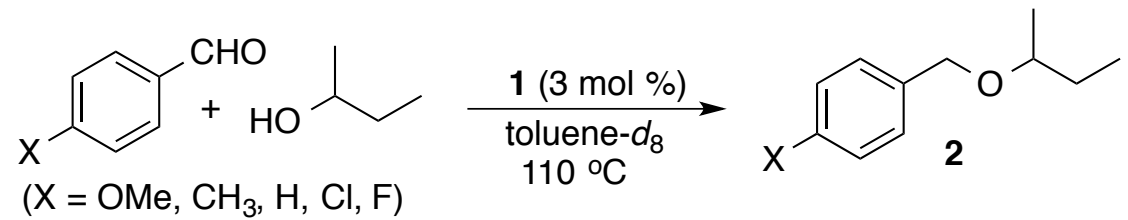

3. Hammett Study. In a glove box, para-substituted benzaldehyde $p-\mathrm{X}-\mathrm{C}_{6} \mathrm{H}_{5} \mathrm{CHO}\left(\mathrm{X}=\mathrm{OCH}_{3}, \mathrm{CH}_{3}, \mathrm{H}\right.$, $\mathrm{Cl}, \mathrm{F})(0.25 \mathrm{mmol}), 2$-butanol $(0.75 \mathrm{mmol})$ and complex 1 (3 mol \%) were dissolved in toluene- $d_{8}(0.5 \mathrm{~mL})$ in six separate J-Young NMR tubes. The tubes were brought out of the box, and stirred in an oil bath set at $110{ }^{\circ} \mathrm{C}$. Each reaction tube was taken out of the oil bath in 20 min intervals, was immediately cooled in an ice water 
bath, and was analyzed by ${ }^{1} \mathrm{H}$ NMR. The $k_{\mathrm{obs}}$ was determined from a first-order plot of $-\ln \left(\left[p-\mathrm{X}-\mathrm{C}_{6} \mathrm{H}_{5} \mathrm{CHO}\right]_{\mathrm{t}} / p-\right.$ $\left.\mathrm{X}-\mathrm{C}_{6} \mathrm{H}_{5} \mathrm{CHO}\right]_{0}$ ) vs. time.

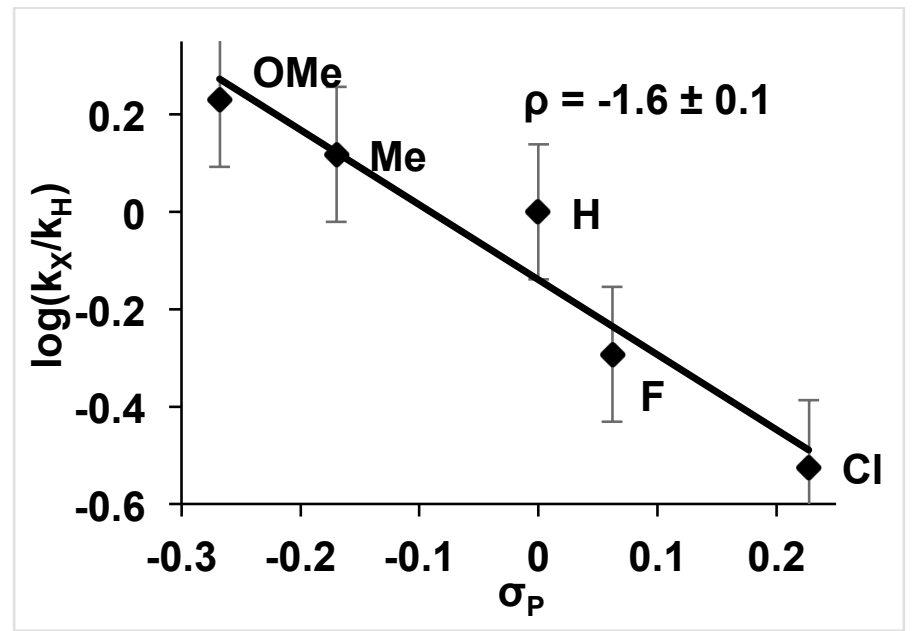

Figure S1. Hammett Plot from the Reaction of $p-\mathrm{X}-\mathrm{C}_{6} \mathrm{H}_{4} \mathrm{CHO}(\mathrm{X}=\mathrm{OMe}, \mathrm{Me}, \mathrm{H}, \mathrm{F}, \mathrm{Cl})$ with 2-Butanol.

4. Solvent Isotope Effect Study. In a glove box, 4-methoxybenzaldehyde (340 mg, $1.5 \mathrm{mmol})$, 2-butanol (463 mg, $6.6 \mathrm{mmol}$ ) and complex 1 (40 mg, $2 \mathrm{~mol} \%$ ) were mixed in a vial, and the solution was divided into five separate $25 \mathrm{~mL}$ Schelenk tubes equiped with magnetic stiring bar. After adding $\mathrm{H}_{2} \mathrm{O}(0.5 \mathrm{~mL})$, each tube was evacuated, and refilled with $\mathrm{N}_{2}$ gas. The tubes were stirred in an oil bath set at $110^{\circ} \mathrm{C}$. Each reaction tube was taken out of the oil bath in 15 min intervals, was immediately cooled in liquid $\mathrm{N}_{2}$ bath, and hexamethylbenzene (10 mg, internal standard) dissolved in $\mathrm{CDCl}_{3}(1 \mathrm{~mL})$ was added. After shaking the reaction tube for $5 \mathrm{~min}, \mathrm{CDCl}_{3}$ layer was separated and was analyzed by ${ }^{1} \mathrm{H}$ NMR. The $k_{\mathrm{H} 2 \mathrm{O}}$ was determined from a first-order plot of $\left.-\ln \left(\left[p-\mathrm{OMe}-\mathrm{C}_{6} \mathrm{H}_{5} \mathrm{CHO}\right]_{t} / p-\mathrm{OMe}-\mathrm{C}_{6} \mathrm{H}_{5} \mathrm{CHO}\right]_{0}\right)$ vs. time. The $k_{\mathrm{D} 2 \mathrm{O}}$ was determined from the analogous experiment by using $\mathrm{D}_{2} \mathrm{O}$. The $k_{\mathrm{H} 2 \mathrm{O}} / k_{\mathrm{D} 2 \mathrm{O}}$ was calculated from the ratio of slopes (Figure $\mathrm{S} 2$ ).

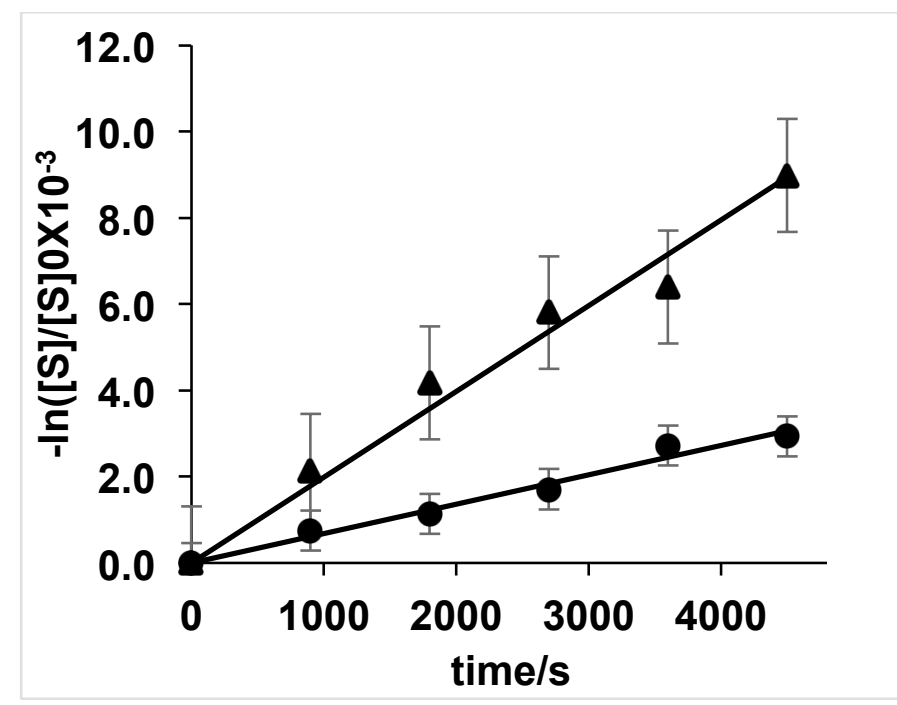

Figure S2. First Order Plot of the 4-Methoxybenzaldehyde with 2-Butanol in $\mathrm{H}_{2} \mathrm{O}$ (triangle) and in $\mathrm{D}_{2} \mathrm{O}$ (circle). 
In a glove box, 4-methoxybenzaldehyde (340 mg, $1.5 \mathrm{mmol})$, 2-propanol (0.5 mL) and complex 1 (50 mg, $2 \mathrm{~mol} \%$ ) were mixed in a vial, and the solution was divided into five separate $25 \mathrm{~mL}$ Schelenk tubes equiped with magnetic stiring bar. The tubes were stirred in an oil bath set at $110{ }^{\circ} \mathrm{C}$. Each reaction tube was taken out of the oil bath in 15 min intervals, was immediately cooled in liquid $\mathrm{N}_{2}$ bath, hexamethylbenzene (10 mg, internal standard) in benzene- $d_{6}(0.5 \mathrm{~mL})$ was added, and the resulting mixture was analyzed by ${ }^{1} \mathrm{H}$ NMR. The $k_{\mathrm{PrOH}}$ was determined from a first-order plot of $\left.-\ln \left(\left[p-\mathrm{OMe}-\mathrm{C}_{6} \mathrm{H}_{5} \mathrm{CHO}\right]_{t} / p-\mathrm{OMe}-\mathrm{C}_{6} \mathrm{H}_{5} \mathrm{CHO}\right]_{0}\right)$ vs. time. The experiment was repeated by using 2-propanol- $d_{1}$ as the solvent to determine $k_{\mathrm{PrOD}}$. The $k_{\mathrm{PrOH}} / k_{\mathrm{PrOD}}$ was calculated from the ratio of slopes.

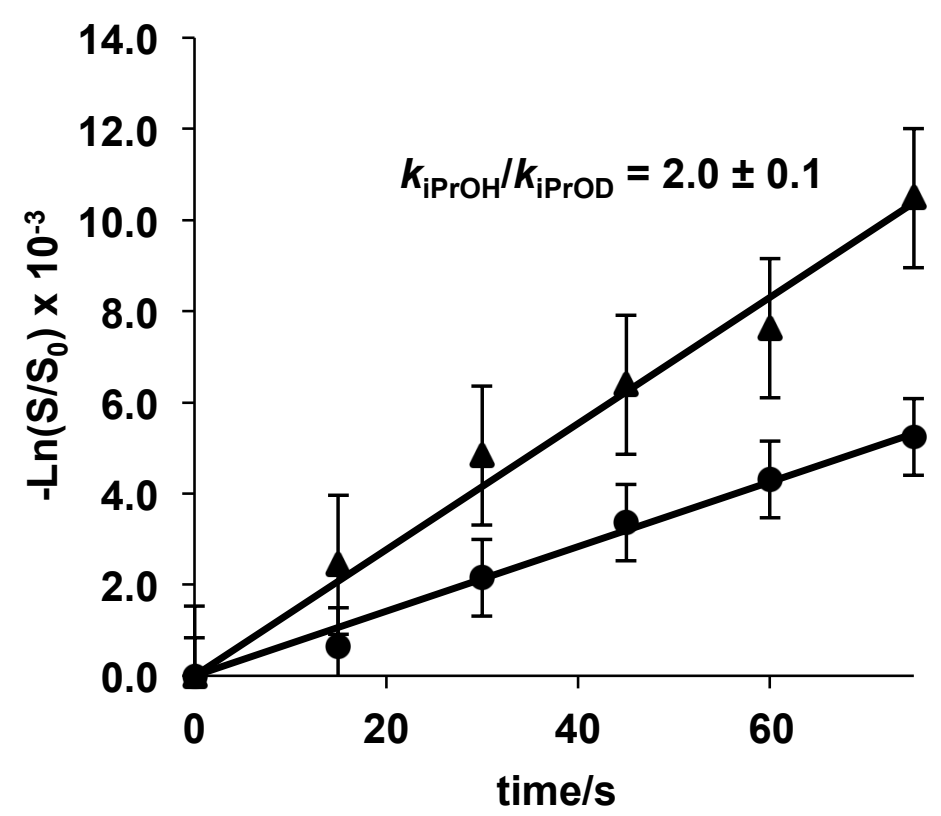

Figure S3. First Order Plot of the 4-Methoxybenzaldehyde with 2-Propanol (triangle) and in 2-Propanol- $d_{1}$ (circle).

5. H/D Exchange Reaction of 4-Methoxybenzaldehyde with 1-Butanol in $\mathrm{D}_{2} \mathrm{O}$. In a glove box, complex 1 (17 mg, $3 \mathrm{~mol} \%$ ) was placed into a $25 \mathrm{~mL}$ Schlenk tube equipped with a Teflon stopcock and a magnetic stirring bar. The tube was brought out of the glove box, and 4-methoxybenzaldehyde (136 mg, 1.0 mmol), 1-butanol (185 mg, $2.5 \mathrm{mmol})$ and $\mathrm{D}_{2} \mathrm{O}(99 \% \mathrm{D}, 1 \mathrm{~mL})$ were added to the tube. The tube was filled with $\mathrm{N}_{2}$, and was stirred in an oil bath set at $110^{\circ} \mathrm{C}$ for $12 \mathrm{~h}$. The reaction tube was taken out of the oil bath, and was cooled to room temperature. After the tube was open to air, the organic layer was extracted with $\mathrm{CH}_{2} \mathrm{Cl}_{2}(2 \mathrm{~mL})$. The organic layer was filtered through a short silica gel column by eluting with $\mathrm{CH}_{2} \mathrm{Cl}_{2}(10 \mathrm{~mL})$, and the filtrate was analyzed by GC and GC-MS. Analytically pure product was isolated by a simple column chromatography 
on silica gel $\left(280-400\right.$ mesh, hexanes $\left./ \mathrm{Et}_{2} \mathrm{O}=40: 1\right)$. The deuterium content of the product $\mathbf{2 f}$ was detemined by ${ }^{1} \mathrm{H}$ and ${ }^{2} \mathrm{H}$ NMR (Figure S4).

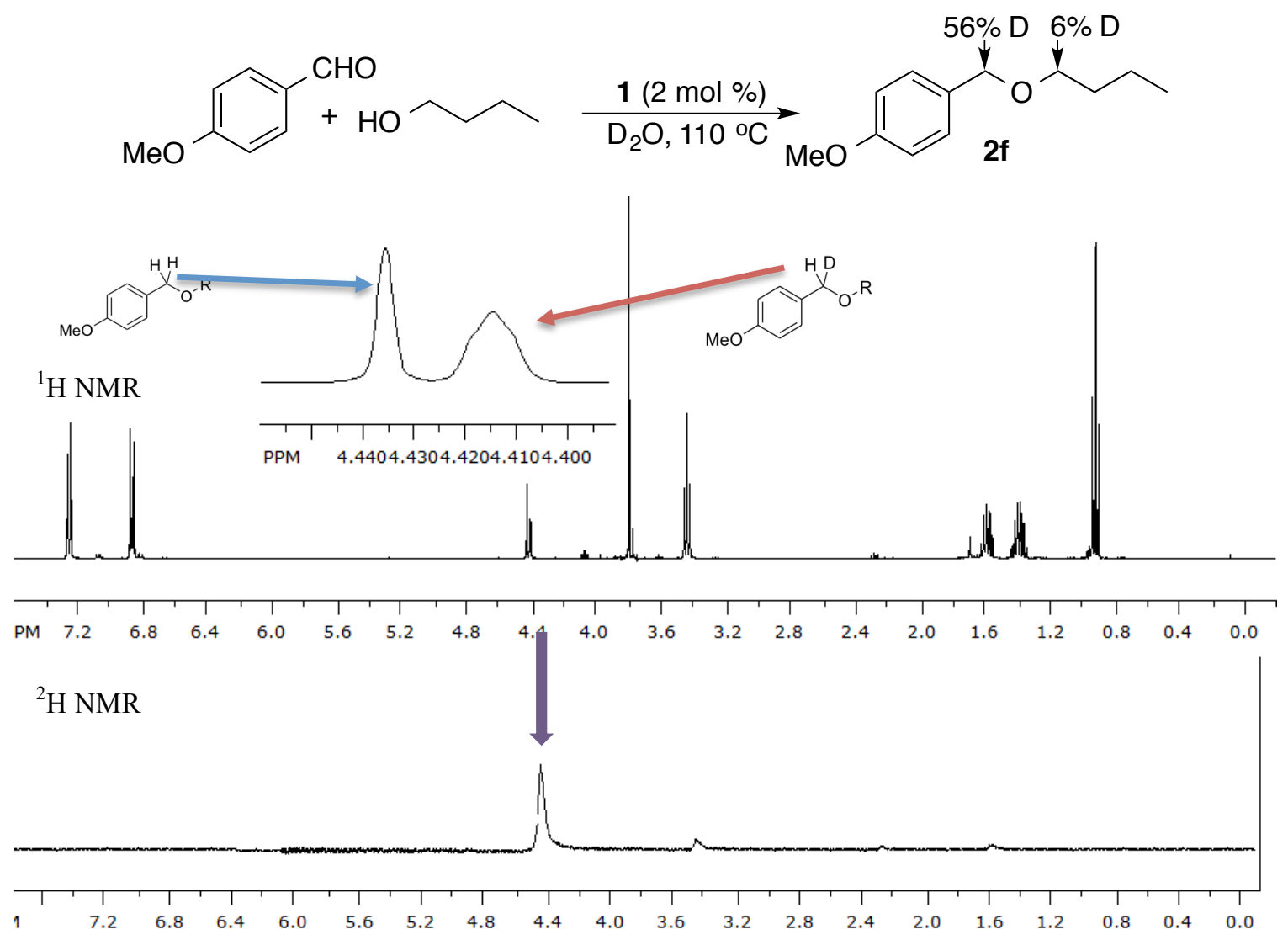

Figure S4. ${ }^{1} \mathrm{H}$ and ${ }^{2} \mathrm{H}$ NMR Spectra of the Product $2 \mathrm{f}$ Isolated from the Reaction of 4-Methoxybenzaldehyde with 1-Butanol in $\mathrm{D}_{2} \mathrm{O}$.

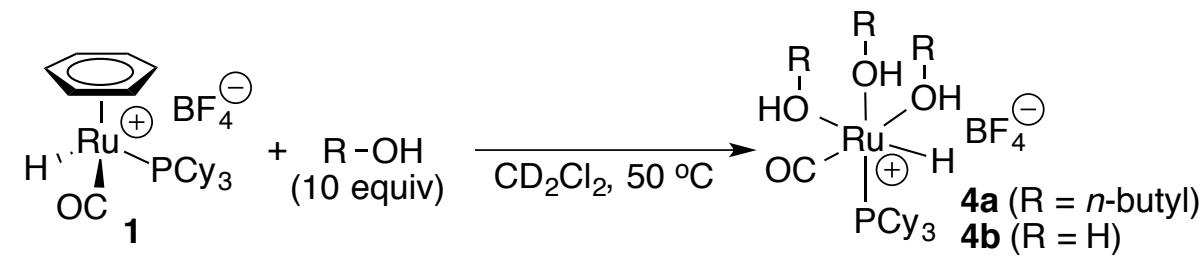

6. Detection and Synthesis of the Alcohol Complexes 4a-4c. In a glove box, complex 1 (40 mg, 0.07 mmol) was dissolved in $\mathrm{CD}_{2} \mathrm{Cl}_{2}(1 \mathrm{~mL})$ in a NMR tube. 1-Butanol (52 mg, 10 equiv) was added via syringe, and the tube was shaken for 5-10 min at room temperature. The reaction progress was monitored by ${ }^{1} \mathrm{H}$ NMR and ${ }^{31} \mathrm{P}$ NMR at $50{ }^{\circ} \mathrm{C}$. After $5 \mathrm{~min}$, the appearance of new ruthenium hydride species as indicated by a new $\mathrm{Ru}-\mathrm{H}$ signal $\left(\delta-18.8\left(\mathrm{~d}, J_{\mathrm{PH}}=31.3 \mathrm{~Hz}\right) \mathrm{ppm}\right)$ and free benzene molecule $(\delta 7.26 \mathrm{ppm})$ was detected by ${ }^{1} \mathrm{H}$ NMR (Figure S5). 


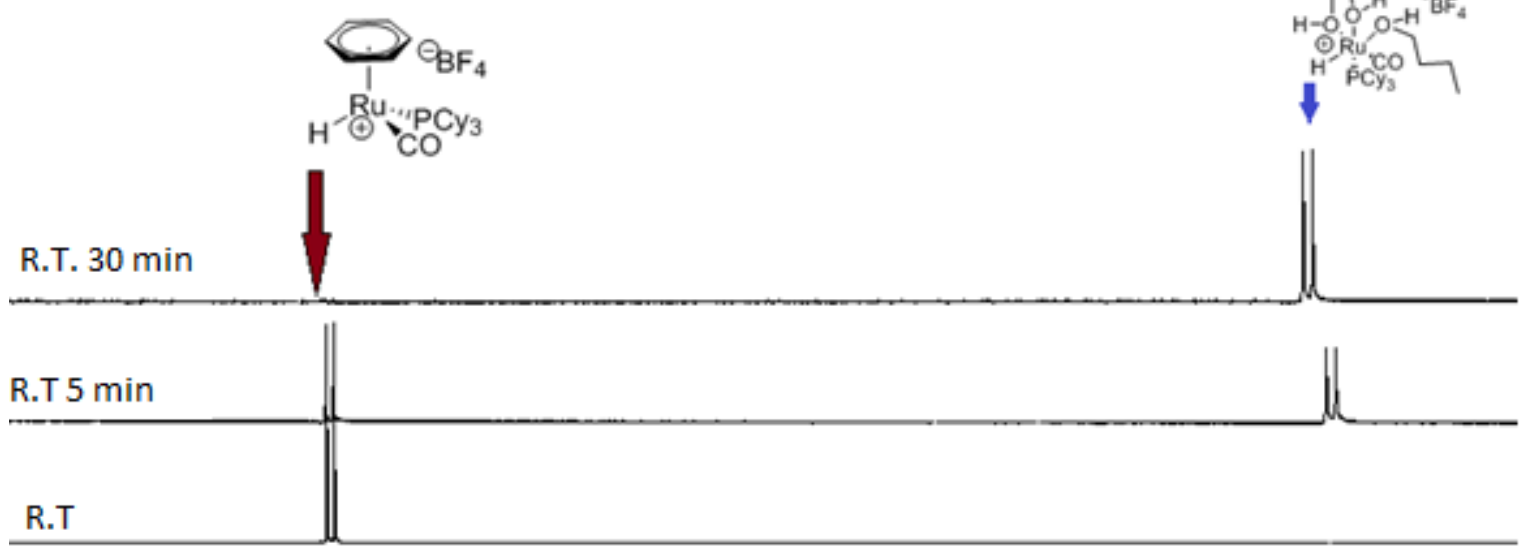

\begin{tabular}{|c|c|c|c|c|c|c|c|c|c|c|c|c|}
\hline$T$ & $T$ & $\mathrm{~T}$ & $T$ & $T$ & $T$ & $T$ & $T$ & $T$ & $T$ & $T$ & $T$ & $\mathrm{~T}$ \\
\hline-8.0 & -9.0 & -10.0 & -11.0 & -12.0 & -13.0 & -14.0 & -15.0 & -16.0 & -17.0 & -18.0 & -19.0 & -20.0 \\
\hline
\end{tabular}

Figure S5. ${ }^{1} \mathrm{H}$ NMR Spectra of the Reaction of 1 with 1-Butanol.

The analogous treatment of 1 (40 mg) with $\mathrm{H}_{2} \mathrm{O}(13 \mathrm{mg}, 10$ equiv) was monitored by NMR. After 5 min at room temperature, the appearance of $\mathbf{4 b}$ was detected by ${ }^{1} \mathrm{H}$ and ${ }^{31} \mathrm{P}$ NMR. Because the complex decomposes within $1 \mathrm{~h}$ at room temperature, both ${ }^{1} \mathrm{H}$ NMR and ${ }^{31} \mathrm{P}$ NMR spectra were recorded at $-10{ }^{\circ} \mathrm{C}$ in this case $\left({ }^{1} \mathrm{H}\right.$ NMR: $\delta-17.7\left(\mathrm{~d}, J_{\mathrm{H}-\mathrm{P}}=30.3 \mathrm{~Hz}\right) \mathrm{ppm},{ }^{31} \mathrm{P}$ NMR: $\left.\delta 73.0 \mathrm{ppm}\right)$. Synthesis of 4c: The treatment of complex 1 (115 mg, $0.2 \mathrm{mmol})$ with 1,1,1-tris(hydroxymethyl)ethane $(24 \mathrm{mg}, 0.2 \mathrm{mmol})$ in acetone $(2 \mathrm{~mL})$, and the mixture was stired for $30 \mathrm{~min}$ at room temperature. The solution was layered with $n$-pentane $(5 \mathrm{~mL})$ to obtain single crystals of $\mathbf{4 c}$ as colorless crystals in $80 \%$ yield.

\section{X-Ray Crystallographic Determination of $3 e$ and $4 c$.}

For 3e: Colorless single crystals of $\mathbf{3 e}$ were grown in $\mathrm{CH}_{2} \mathrm{Cl}_{2}$ at room temperature. A suitable crystal with the dimension of $0.42 \times 0.12 \times 0.05 \mathrm{~mm}^{3}$ was selected and mounted on an Oxford SuperNova diffractometer equipped with dual microfocus $\mathrm{Cu} / \mathrm{Mo} \mathrm{X}$-ray sources, X-ray mirror optics, and Atlas CCD area detector. A total of 11497 reflection data were collected by using $\operatorname{MoK} \alpha(\lambda=1.54184)$ radiation while the crystal sample was cooled at $100.00 \mathrm{~K}$ during the data collection. Using Olex2, the molecular structure was solved with the ShelXS structure solution program by using Direct Methods, and the data was refined with the XL refinement package using Least Squares minimization. The molecular structure of 3e is shown in Figure S6.

For $\mathbf{4 c}$ : Colorless single crystals of $\mathbf{4 c}$ were grown in acetone/n-pentane at room temperature. A suitable crystal with the dimension of $0.3068 \times 0.2254 \times 0.0989 \mathrm{~mm}^{3}$ was selected and mounted on an Oxford 
SuperNova diffractometer equipped with dual microfocus $\mathrm{Cu} / \mathrm{Mo}$ X-ray sources, X-ray mirror optics, and Atlas CCD area detector. A total of 55980 reflection data were collected by using MoK $\alpha(\lambda=1.54184)$ radiation while the crystal sample was cooled at $100.00 \mathrm{~K}$ during the data collection. Using Olex2, the molecular structure was solved with the ShelXS structure solution program by using Direct Methods, and the data was refined with the XL refinement package using Least Squares minimization. The molecular structure of $\mathbf{4 c}$ is shown in Figure S7.

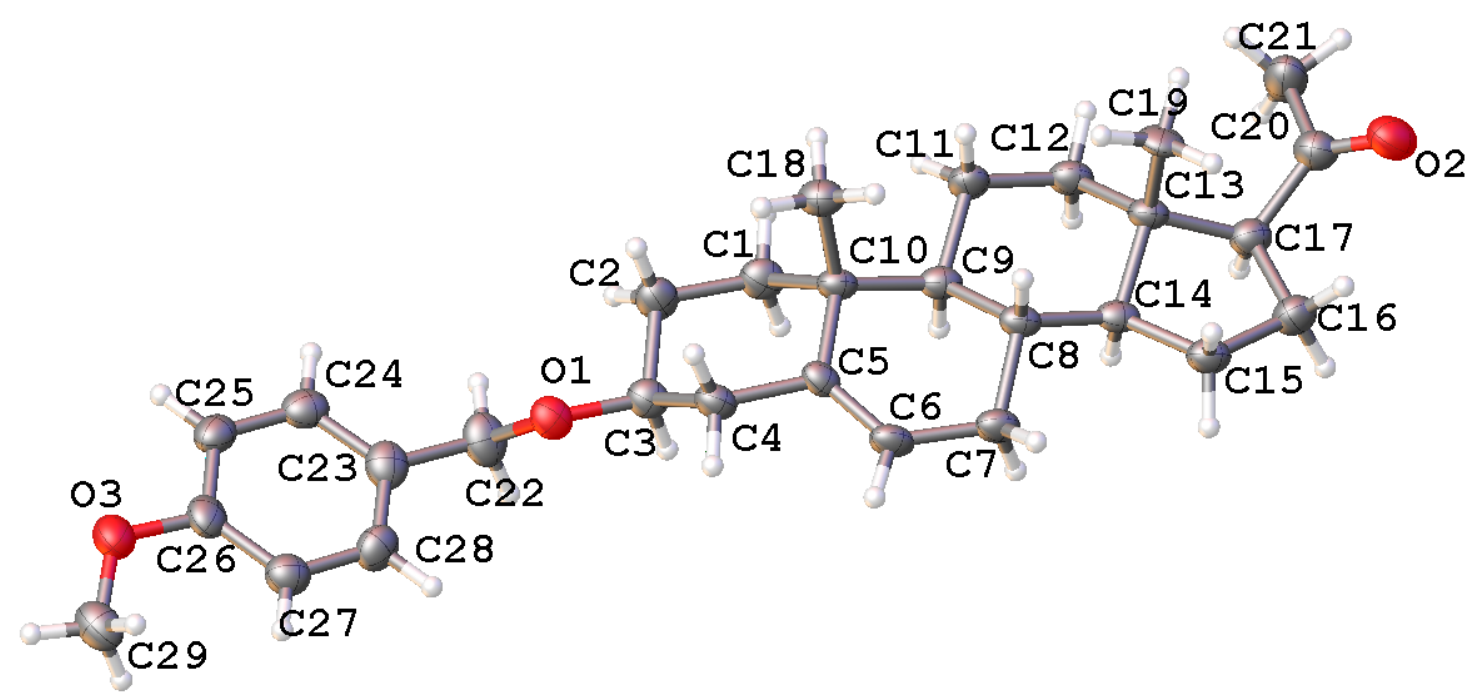

Figure S6. Molecular Structure of 3e.

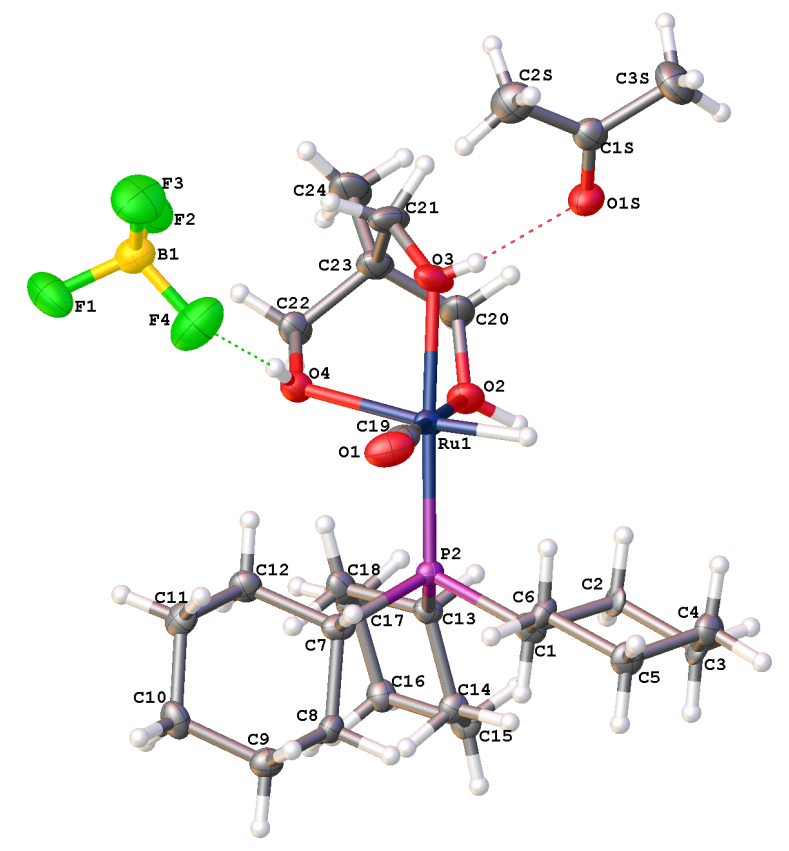

Figure S7. Molecular Structure of 4c. 


\section{Characterization Data of the Products.}

Data for 2a: Colorless oil (82\%, $134 \mathrm{mg}) .{ }^{1} \mathrm{H}$ NMR (400 MHz, $\left.\mathrm{CDCl}_{3}\right) \delta$ 7.77-

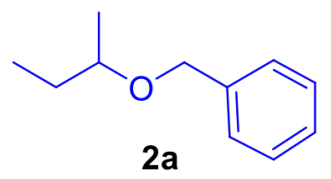
7.95 (m, 3H), 7.42-7.59 (m, 2H), 4.57 (d, $J=11.9 \mathrm{~Hz}, 1 \mathrm{H}), 4.49$ (d, $J=11.9 \mathrm{~Hz}, 1 \mathrm{H})$, 3.52 (sextet, $J=6.1 \mathrm{~Hz}, 1 \mathrm{H}), 1.63-1.74(\mathrm{~m}, 1 \mathrm{H}), 1.47-1.61(\mathrm{~m}, 1 \mathrm{H}), 1.25(\mathrm{~d}, J=6.1 \mathrm{~Hz}$, $3 \mathrm{H}), 0.97$ (t, $J=7.4 \mathrm{~Hz}, 3 \mathrm{H}) \mathrm{ppm} ;{ }^{13} \mathrm{C}\left\{{ }^{1} \mathrm{H}\right\} \mathrm{NMR}\left(100 \mathrm{MHz}, \mathrm{CDCl}_{3}\right) \delta$ 138.2, 128.4, 127.8, 127.6, 72.1, 70.2, 29.2, 19.2, 9.8 ppm; GC-MS $m / z=164\left(\mathrm{M}^{+}\right) .{ }^{1} \mathrm{H}$ and ${ }^{13} \mathrm{C}$ NMR spectral data are in good agreement with the literature data. ${ }^{\mathrm{S} 1}$

Data for 2b: Colorless oil $(95 \%, 184 \mathrm{mg}) .{ }^{1} \mathrm{H}$ NMR $\left(400 \mathrm{MHz}, \mathrm{CDCl}_{3}\right) \delta$

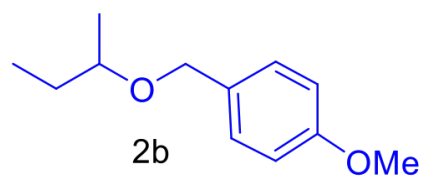

7.29 (d, $J=8.3 \mathrm{~Hz}, 2 \mathrm{H}), 6.89$ (d, $J=8.3 \mathrm{~Hz}, 2 \mathrm{H}), 4.51$ (d, $J=11.7 \mathrm{~Hz}, 1 \mathrm{H}), 4.42$ (d, $J=11.7 \mathrm{~Hz}, 1 \mathrm{H}), 3.81$ (s, 3H), 3.44 (sextet, $J=7.0 \mathrm{~Hz}, 1 \mathrm{H}), 1.61$ (dq, $J=14.7$, $7.9 \mathrm{~Hz}, 1 \mathrm{H}), 1.49$ (qd, $J=14.0,7.9 \mathrm{~Hz}, 1 \mathrm{H}), 1.19$ (d, $J=6.1 \mathrm{~Hz}, 3 \mathrm{H}), 0.93$ (t, $J=$ $7.9 \mathrm{~Hz}, 3 \mathrm{H}) \mathrm{ppm} ;{ }^{13} \mathrm{C}\left\{{ }^{1} \mathrm{H}\right\} \mathrm{NMR}\left(100 \mathrm{MHz}, \mathrm{CDCl}_{3}\right) \delta 158.9,131.2,129.1,113.7,75.8,69.9,55.2,29.2,19.2$, $9.8 \mathrm{ppm}$; GC-MS $m / z=194\left(\mathrm{M}^{+}\right) .{ }^{1} \mathrm{H}$ and ${ }^{13} \mathrm{C}$ NMR spectral data are in good agreement with the literature data. $^{\mathrm{S} 2}$

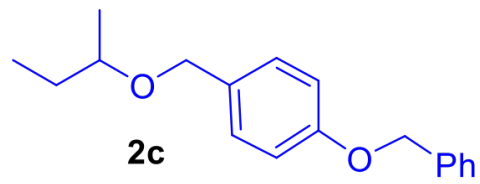

Data for 2c: White solid $(97 \%, 261 \mathrm{mg}) .{ }^{1} \mathrm{H}$ NMR $\left(400 \mathrm{MHz}, \mathrm{CDCl}_{3}\right) \delta$ 7.27-7.47 (m, 7H), 6.95-6.99 (m, 2H), 5.09 (s, 2H), 4.52 (d, $J=11.3 \mathrm{~Hz}, 1 \mathrm{H})$, $4.43(\mathrm{~d}, J=11.3 \mathrm{~Hz}, 1 \mathrm{H}), 3.46$ (sextet, $J=5.9 \mathrm{~Hz}, 1 \mathrm{H}), 1.58-1.74(\mathrm{~m}, 1 \mathrm{H})$, 1.45-1.56 (m, 1H), $1.20(\mathrm{~d}, J=6.3 \mathrm{~Hz}, 3 \mathrm{H}), 0.94(\mathrm{t}, J=7.4 \mathrm{~Hz}, 3 \mathrm{H}) \mathrm{ppm} ;{ }^{13} \mathrm{C}\left\{{ }^{1} \mathrm{H}\right\} \mathrm{NMR}\left(100 \mathrm{MHz}, \mathrm{CDCl}_{3}\right) \delta$ $158.1,137.0,131.5,129.1,128.5,127.8,127.4,114.6,75.9,69.9,69.9,29.2,19.2,9.8$ ppm; GC-MS $m / z=270$ $\left(\mathrm{M}^{+}\right)$; Anal. Calcd for $\mathrm{C}_{18} \mathrm{H}_{22} \mathrm{O}_{2}: \mathrm{C}, 79.96 ; \mathrm{H}, 8.20$. Found: $\mathrm{C}, 79.88 ; \mathrm{H}, 8.31$.

Data for 2d: Colorless liquid (68\%, $134 \mathrm{mg}) .{ }^{1} \mathrm{H}$ NMR (400 MHz, $\left.\mathrm{CDCl}_{3}\right) \delta$

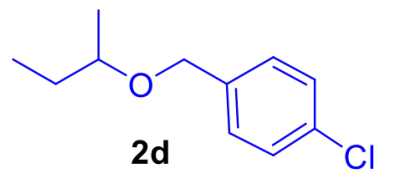
7.20-7.23 (m, 4H), 4.45 (d, $J=12.2 \mathrm{~Hz}, 1 \mathrm{H}), 4.36(\mathrm{~d}, J=12.2 \mathrm{~Hz}, 1 \mathrm{H}), 3.36$ (sextet, $J=6.1 \mathrm{~Hz}, 1 \mathrm{H}), 1.51-1.61(\mathrm{~m}, 1 \mathrm{H}), 1.35-1.47(\mathrm{~m}, 1 \mathrm{H}), 1.11(\mathrm{~d}, J=6.4 \mathrm{~Hz}, 3 \mathrm{H})$,

$0.85(\mathrm{t}, J=7.5 \mathrm{~Hz}, 3 \mathrm{H}) \mathrm{ppm} ;{ }^{13} \mathrm{C}\left\{{ }^{1} \mathrm{H}\right\}$ NMR $\left(100 \mathrm{MHz}, \mathrm{CDCl}_{3}\right) \delta 137.7,133.0$, 128.8, 128.4, 76.4, 69.5, 29.2, 19.1, 9.8 ppm; GC-MS m/z $=198\left(\mathrm{M}^{+}\right)$; Anal. Calcd for $\mathrm{C}_{11} \mathrm{H}_{15} \mathrm{ClO}$ : C, 66.50; $\mathrm{H}$, 7.61. Found: C, 66.48; H, 7.52.

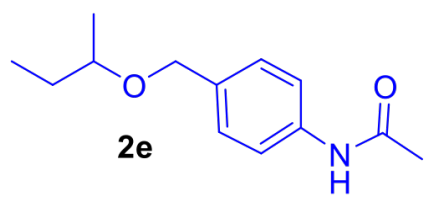

Data for 2e: White solid (85\%, $187 \mathrm{mg}) .{ }^{1} \mathrm{H}$ NMR (400 MHz, $\left.\mathrm{CDCl}_{3}\right) \delta$ 7.55 (br s, 1H), 7.47 (d, $J=8.61 \mathrm{~Hz}, 2 \mathrm{H}), 7.30$ (d, $J=8.2 \mathrm{~Hz}, 2 \mathrm{H}), 4.52$ (d, $J=$ $11.7 \mathrm{~Hz}, 1 \mathrm{H}), 4.43$ (d, $J=11.7 \mathrm{~Hz}, 1 \mathrm{H}), 3.44$ (sextet, $J=6.1 \mathrm{~Hz}, 1 \mathrm{H}), 2.16$ (s, 3H), 1.61 (ddd, $J=13.7,7.4,6.3 \mathrm{~Hz}, 1 \mathrm{H}), 1.48$ (ddd, $J=13.7,7.4,5.8 \mathrm{~Hz}, 1 \mathrm{H}), 1.18$ (d, $J=6.3 \mathrm{~Hz}, 3 \mathrm{H}), 0.92$ (t, $J=7.4 \mathrm{~Hz}, 3 \mathrm{H}) \mathrm{ppm} ;{ }^{13} \mathrm{C}\left\{{ }^{1} \mathrm{H}\right\} \mathrm{NMR}\left(100 \mathrm{MHz}, \mathrm{CDCl}_{3}\right) \delta 168.4,137.0,135.0,128.3,199.8,76.1,69.8,29.1$, 24.5, 19.1, 9.8 ppm; GC-MS $m / z=221\left(\mathrm{M}^{+}\right)$; Anal. Calcd for $\mathrm{C}_{13} \mathrm{H}_{19} \mathrm{NO}_{2}$ : C, 70.56; H, 8.65. Found: C, 70.48; H, 8.61 . 


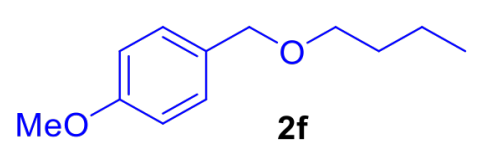

Data for 2f: Yellow oil $(98 \%, 190 \mathrm{mg}) .{ }^{1} \mathrm{H}$ NMR $\left(400 \mathrm{MHz}, \mathrm{CDCl}_{3}\right) \delta$ $7.28(\mathrm{~d}, J=8.5 \mathrm{~Hz}, 2 \mathrm{H}), 6.90(\mathrm{~d}, J=8.5 \mathrm{~Hz}, 2 \mathrm{H}), 4.45(\mathrm{~s}, 2 \mathrm{H}), 3.81(\mathrm{~s}, 3 \mathrm{H})$, $3.46(\mathrm{t}, J=6.6 \mathrm{~Hz}, 2 \mathrm{H}$ ), 1.60 (quintet, $J=6.2 \mathrm{~Hz}, 2 \mathrm{H}$ ), 1.41 (sextet, $J=7.4 \mathrm{~Hz}$, 2H), $0.93(\mathrm{t}, J=7.4 \mathrm{~Hz}, 3 \mathrm{H}) \mathrm{ppm} ;{ }^{13} \mathrm{C}\left\{{ }^{1} \mathrm{H}\right\} \operatorname{NMR}\left(100 \mathrm{MHz}, \mathrm{CDCl}_{3}\right) \delta$ 159.0, 130.7, 129.1, 113.6, 72.4, 69.8, 55.1, 31.8, 19.3, $13.9 \mathrm{ppm}$; GC-MS $m / z=194\left(\mathrm{M}^{+}\right) ;{ }^{1} \mathrm{H}$ and ${ }^{13} \mathrm{C}$ NMR spectral data are in good agreement with the literature data. ${ }^{\mathrm{S} 2}$

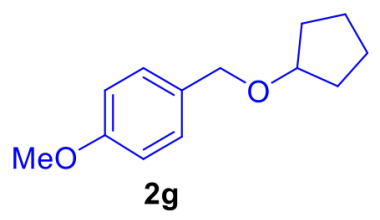

Data for 2g: Colorless oil $(95 \%, 195 \mathrm{mg}) .{ }^{1} \mathrm{H}$ NMR $\left(400 \mathrm{MHz}, \mathrm{CDCl}_{3}\right) \delta 7.16-$ $7.22(\mathrm{~m}, 2 \mathrm{H}), 6.77-6.82(\mathrm{~m}, 2 \mathrm{H}), 4.33(\mathrm{~s}, 2 \mathrm{H}), 3.87-3.94(\mathrm{~m}, 1 \mathrm{H}), 3.72(\mathrm{~s}, 3 \mathrm{H}), 1.59-$ $1.71(\mathrm{~m}, 6 \mathrm{H}), 1.39-1.49(\mathrm{~m}, 2 \mathrm{H}) \mathrm{ppm} ;{ }^{13} \mathrm{C}\left\{{ }^{1} \mathrm{H}\right\}$ NMR $\left(100 \mathrm{MHz}, \mathrm{CDCl}_{3}\right) \delta 158.9$, $131.0,129.2,129.1,113.7,80.5,70.3,55.2,32.3,23.6,23.5 \mathrm{ppm} ;$ GC-MS $m / z=206$ $\left(\mathrm{M}^{+}\right) ;{ }^{1} \mathrm{H}$ and ${ }^{13} \mathrm{C}$ NMR spectral data are in good agreement with the literature data. ${ }^{\mathrm{S} 3}$

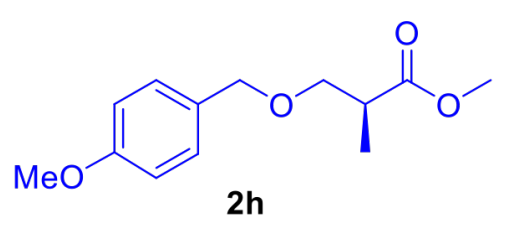

Data for 2h: Colorless oil (91\%, $216 \mathrm{mg}) .{ }^{1} \mathrm{H}$ NMR (400 MHz, $\left.\mathrm{CDCl}_{3}\right)$

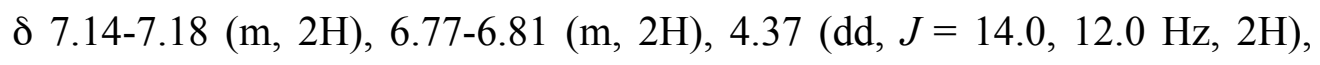
$3.71(\mathrm{~s}, 3 \mathrm{H}), 3.60$ (s, 3H), 3.54 (dd, $J=9.0,7.4 \mathrm{~Hz}, 1 \mathrm{H}), 3.37$ (dd, $J=9.2$, $6.1 \mathrm{~Hz}, 1 \mathrm{H}), 2.68$ (qt, $J=7.5,6.1 \mathrm{~Hz}, 1 \mathrm{H}), 1.08(\mathrm{~d}, J=7.0 \mathrm{~Hz}, 3 \mathrm{H}) \mathrm{ppm}$; ${ }^{13} \mathrm{C}\left\{{ }^{1} \mathrm{H}\right\}$ NMR $\left(100 \mathrm{MHz}, \mathrm{CDCl}_{3}\right) \delta 175.2,159.1,130.1,129.1,113.6,72.6$, 71.5, 55.1, 51.6, 40.1, $13.9 \mathrm{ppm}$; GC-MS $m / z=238\left(\mathrm{M}^{+}\right) ;{ }^{1} \mathrm{H}$ and ${ }^{13} \mathrm{C}$ NMR spectral data are in good agreement with the literature data. ${ }^{\mathrm{S}}$

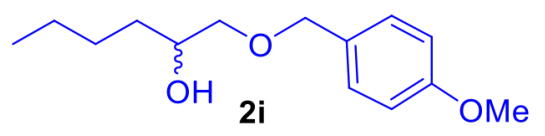

Data for 2i: Colorless oil $(91 \%, 216 \mathrm{mg}) .{ }^{1} \mathrm{H}$ NMR $(400 \mathrm{MHz}$, $\left.\mathrm{CDCl}_{3}\right) \delta$ 7.24-7.30 (m, 2H), 6.87-6.92 (m, 2H), $4.49(\mathrm{~s}, 2 \mathrm{H}), 3.81(\mathrm{~s}, 3 \mathrm{H})$, 3.49 (dd, $J=9.4,3.1 \mathrm{~Hz}, 1 \mathrm{H}), 3.3$ (dd, $J=9.4,7.8 \mathrm{~Hz}, 1 \mathrm{H}), 2.39$ (br s, $1 \mathrm{H}$ ), 1.26-1.51 (m, 7H), $0.90(\mathrm{t}, J=7.4 \mathrm{~Hz}, 3 \mathrm{H}) \mathrm{ppm} ;{ }^{13} \mathrm{C}\left\{{ }^{1} \mathrm{H}\right\} \mathrm{NMR}(100 \mathrm{MHz}$, $\left.\mathrm{CDCl}_{3}\right) \delta 159.2,130.0,129.4,113.8,74.3,72.9,70.4,55.2,32.8,27.7,22.7,14.0$ ppm; GC-MS $m / z=238\left(\mathrm{M}^{+}\right)$; ${ }^{1} \mathrm{H}$ and ${ }^{13} \mathrm{C}$ NMR spectral data are in good agreement with the literature data. ${ }^{\mathrm{S} 5}$

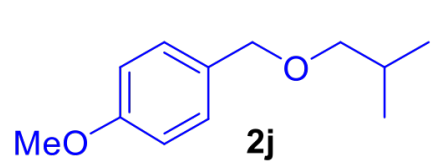

Data for $\mathbf{2 j}$ : Colorless oil $(86 \%, 166 \mathrm{mg}),{ }^{1} \mathrm{H}$ NMR $\left(400 \mathrm{MHz}, \mathrm{CDCl}_{3}\right) \delta$ 7.28 (d, $J=8.4 \mathrm{~Hz}, 2 \mathrm{H}), 6.90$ (d, $J=8.7 \mathrm{~Hz}, 2 \mathrm{H}), 4.45$ (s, 2H), 3.82 (s, 3H), 3.49 (t, $J=6.8 \mathrm{~Hz}, 2 \mathrm{H}), 1.74(\mathrm{dt}, J=13.4,6.7 \mathrm{~Hz}, 1 \mathrm{H}), 1.52(\mathrm{qd}, J=6.8,0.9 \mathrm{~Hz}, 2 \mathrm{H})$, $0.92(\mathrm{~d}, J=7.7 \mathrm{~Hz}, 6 \mathrm{H}) \mathrm{ppm} ;{ }^{13} \mathrm{C}\left\{{ }^{1} \mathrm{H}\right\} \mathrm{NMR}\left(100 \mathrm{MHz}, \mathrm{CDCl}_{3}\right) \delta 159.0,130.7$, 129.2, 113.7, 72.5, 68.5, 55.2, 38.5, $22.6 \mathrm{ppm}$; GC-MS $m / z=194\left(\mathrm{M}^{+}\right) ;{ }^{1} \mathrm{H}$ and ${ }^{13} \mathrm{C}$ NMR spectral data are in good agreement with the literature data. ${ }^{\mathrm{S} 6}$

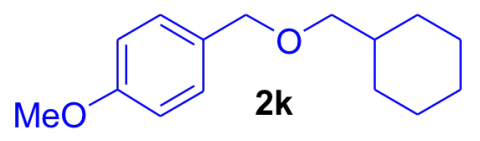

Data for 2k: Yellow oil $(88 \%, 201 \mathrm{mg}) .{ }^{1} \mathrm{H}$ NMR $\left(400 \mathrm{MHz}, \mathrm{CDCl}_{3}\right) \delta$ $7.13(\mathrm{~d}, J=8.7 \mathrm{~Hz}, 2 \mathrm{H}), 6.9$ (d, $J=8.6 \mathrm{~Hz}, 2 \mathrm{H}), 4.47$ (s, 2H), 3.80 (s, 3H), 
$3.29(\mathrm{~d}, J=6.5 \mathrm{~Hz}, 2 \mathrm{H}), 1.62-1.95(\mathrm{~m}, 5 \mathrm{H}), 1.15-1.49(\mathrm{~m}, 4 \mathrm{H}), 0.92-1.05(\mathrm{~m}, 2 \mathrm{H}) \mathrm{ppm} ;{ }^{13} \mathrm{C}\left\{{ }^{1} \mathrm{H}\right\} \mathrm{NMR}(100$ $\left.\mathrm{MHz}_{,} \mathrm{CDCl}_{3}\right) \delta 157.8,133.6,129.6,113.7,75.9,72.5,55.1,55.1,40.0,38.0,30.1,26.6,25.8 \mathrm{ppm}$; GC-MS m/z $=234\left(\mathrm{M}^{+}\right)$; Anal. Calcd for $\mathrm{C}_{15} \mathrm{H}_{22} \mathrm{O}_{2}$ : C, 76.88; H, 9.46. Found: C, 76.48; H, 9.51.

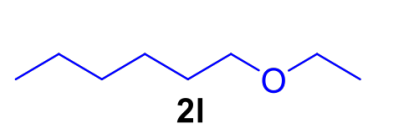

Data for 21: Colorless volatile liquid (71\%, $92 \mathrm{mg}) .{ }^{1} \mathrm{H}$ NMR (400 MHz, $\left.\mathrm{CDCl}_{3}\right) \delta 3.37(\mathrm{t}, J=6.5 \mathrm{~Hz}, 2 \mathrm{H}), 3.50(\mathrm{q}, J=11.9 \mathrm{~Hz}, 2 \mathrm{H}), 1.31-1.51(\mathrm{~m}, 8 \mathrm{H}), 1.10$ $(\mathrm{t}, J=6.5 \mathrm{~Hz}, 3 \mathrm{H}), 0.88(\mathrm{t}, J=6.5 \mathrm{~Hz}, 3 \mathrm{H}) \mathrm{ppm} ;{ }^{13} \mathrm{C}\left\{{ }^{1} \mathrm{H}\right\} \mathrm{NMR}\left(100 \mathrm{MHz}, \mathrm{CDCl}_{3}\right) \delta 70.4,66.6,31.8,30.0$, 22.7, 22.6, 15.2, $14.1 \mathrm{ppm}$; GC-MS $m / z=130\left(\mathrm{M}^{+}\right) ;{ }^{1} \mathrm{H}$ and ${ }^{13} \mathrm{C}$ NMR spectral data are in good agreement with the literature data. ${ }^{\mathrm{S} 7}$

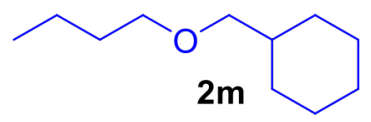

Data for 2m: Colorless liquid (76\%, $129 \mathrm{mg}) .{ }^{1} \mathrm{H}$ NMR $\left(400 \mathrm{MHz}, \mathrm{CDCl}_{3}\right) \delta$ $3.29(\mathrm{t}, J=6.6 \mathrm{~Hz}, 2 \mathrm{H}), 3.08(\mathrm{~d}, J=6.0 \mathrm{~Hz}, 2 \mathrm{H}), 1.52-1.71(\mathrm{~m}, 5 \mathrm{H}), 1.41-1.52(\mathrm{~m}$, 2H), 1.22-1.34 (m, 2H), 0.98-1.22 (m, 4H), 0.73-0.89 (m, 5H) ppm; ${ }^{13} \mathrm{C}\left\{{ }^{1} \mathrm{H}\right\} \mathrm{NMR}$ $\left(100 \mathrm{MHz}, \mathrm{CDCl}_{3}\right) \delta 76.8,70.8,38.0,31.8,30.1,26.7,25.9,19.3,13.9 \mathrm{ppm} ; \mathrm{GC}-\mathrm{MS} m / z=170\left(\mathrm{M}^{+}\right) .{ }^{1} \mathrm{H}$ and ${ }^{13} \mathrm{C}$ NMR spectral data are in good agreement with the literature data. ${ }^{\mathrm{s} 8}$

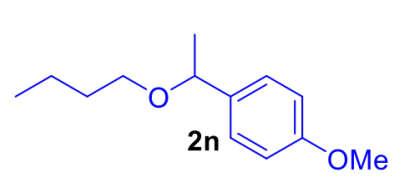

Data for 2n: Colorless oil (88\%, $166 \mathrm{mg}) .{ }^{1} \mathrm{H} \mathrm{NMR}\left(400 \mathrm{MHz}, \mathrm{CDCl}_{3}\right) \delta 6.93$ $(\mathrm{d}, J=8.7 \mathrm{~Hz}, 2 \mathrm{H}), 6.57(\mathrm{~d}, J=8.8 \mathrm{~Hz}, 2 \mathrm{H}), 4.03(\mathrm{q}, J=6.4 \mathrm{~Hz}, 1 \mathrm{H}), 3.49(\mathrm{~s}, 3 \mathrm{H})$, $2.96(\mathrm{t}, J=6.6 \mathrm{~Hz}, 2 \mathrm{H}), 1.18-1.28(\mathrm{~m}, 2 \mathrm{H}), 1.11(\mathrm{~d}, J=6.4 \mathrm{~Hz}, 3 \mathrm{H}), 0.98-1.09(\mathrm{~m}$, $2 \mathrm{H}), 0.58(\mathrm{t}, J=7.4 \mathrm{~Hz}, 3 \mathrm{H}) \mathrm{ppm} ;{ }^{13} \mathrm{C}\left\{{ }^{1} \mathrm{H}\right\} \mathrm{NMR}\left(100 \mathrm{MHz}, \mathrm{CDCl}_{3}\right) \delta 158.8,136.3$, 127.2, 113.6, 77.3, 68.1, 55.1, 32.0, 24.1 19.3, $13.9 \mathrm{ppm}$; GC-MS $m / z=208\left(\mathrm{M}^{+}\right) .{ }^{1} \mathrm{H}$ and ${ }^{13} \mathrm{C}$ NMR spectral data are in good agreement with the literature data. ${ }^{\text {s9 }}$

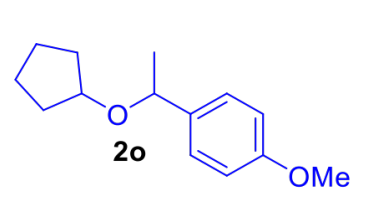

Data for 2o: Colorless oil (93\%, $204 \mathrm{mg}) .{ }^{1} \mathrm{H}$ NMR (400 MHz, $\left.\mathrm{CDCl}_{3}\right) \delta 7.26(\mathrm{~d}$, $J=8.4 \mathrm{~Hz}, 2 \mathrm{H}), 6.89$ (d, $J=8.5 \mathrm{~Hz}, 2 \mathrm{H}), 4.43$ (q, $J=6.5 \mathrm{~Hz}, 1 \mathrm{H}), 3.82$ (s, 3H), $1.41-$ $1.77(\mathrm{~m}, 9 \mathrm{H}), 1.39(\mathrm{~d}, J=6.5 \mathrm{~Hz}, 3 \mathrm{H}) \mathrm{ppm} ;{ }^{13} \mathrm{C}\left\{{ }^{1} \mathrm{H}\right\} \mathrm{NMR}\left(100 \mathrm{MHz}, \mathrm{CDCl}_{3}\right) \delta$ $158.7,136.7,127.4,113.6,78.3,74.9,55.2,33.0,31.8,24.6,23.5,23.4$ ppm; GC-MS $m / z=220\left(\mathrm{M}^{+}\right) .{ }^{1} \mathrm{H}$ and ${ }^{13} \mathrm{C}$ NMR spectral data are in good agreement with the literature data. ${ }^{\mathrm{S} 10}$

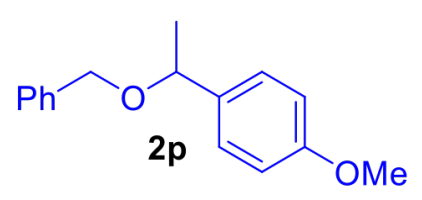

Data for 2p: White solid (55\%, $133 \mathrm{mg}) .{ }^{1} \mathrm{H}$ NMR (400 $\left.\mathrm{MHz}, \mathrm{CDCl}_{3}\right) \delta$ 7.10-7.33 (m, 7H), 6.72-6.87 (m, 2H), $4.38(\mathrm{q}, J=6.5 \mathrm{~Hz}, 1 \mathrm{H}), 4.35$ (d, $J=11.9$ $\mathrm{Hz}, 1 \mathrm{H}), 4.19$ (d, $J=11.9 \mathrm{~Hz}, 1 \mathrm{H}), 3.75$ (s, 3H), 1.39 (d, $J=6.5 \mathrm{~Hz}, 3 \mathrm{H}) \mathrm{ppm}$;

${ }^{13} \mathrm{C}\left\{{ }^{1} \mathrm{H}\right\}$ NMR $\left(100 \mathrm{MHz}, \mathrm{CDCl}_{3}\right) \delta 159.0,138.9,135.7,128.3,127.7,127.6$, 127.4, 113.8, 76.7, 70.0, 55.3, $24.1 \mathrm{ppm}$; GC-MS $m / z=242\left(\mathrm{M}^{+}\right) ;{ }^{1} \mathrm{H}$ and ${ }^{13} \mathrm{C}$ NMR spectral data are in good agreement with the literature data. ${ }^{\text {S11 }}$

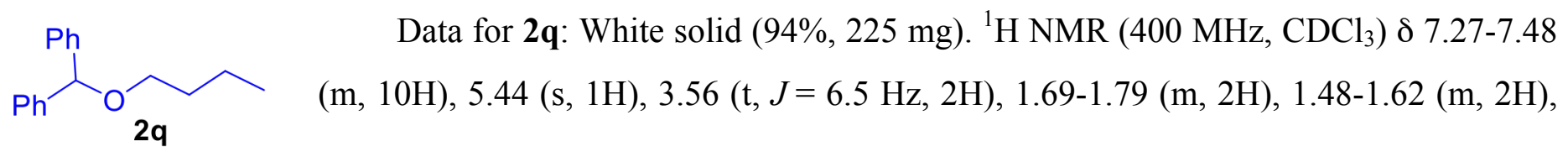


$1.02(\mathrm{t}, J=7.4 \mathrm{~Hz}, 3 \mathrm{H}) \mathrm{ppm} ;{ }^{13} \mathrm{C}\left\{{ }^{1} \mathrm{H}\right\} \mathrm{NMR}\left(100 \mathrm{MHz}, \mathrm{CDCl}_{3}\right) \delta 142.6,128.3,128.3,128.2,128.2,127.2$, $126.9,126.9,126.9,126.8,83.5,68.9,32.0,19.4,13.9 \mathrm{ppm}$; GC-MS $m / z=240\left(\mathrm{M}^{+}\right) ;{ }^{1} \mathrm{H}$ and ${ }^{13} \mathrm{C}$ NMR spectral data are in good agreement with the literature data. ${ }^{\mathrm{S} 12}$

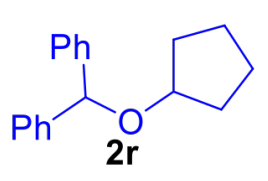

Data for 2r: White solid (92\%, $231 \mathrm{mg}) .{ }^{1} \mathrm{H}$ NMR (400 MHz, $\left.\mathrm{CDCl}_{3}\right) \delta$ 7.23-7.52 (m, $10 \mathrm{H}), 5.54(\mathrm{~s}, 1 \mathrm{H}), 4.05-4.16(\mathrm{~m}, 1 \mathrm{H}), 1.74-1.96(\mathrm{~m}, 6 \mathrm{H}), 1.54-1.70(\mathrm{~m}, 2 \mathrm{H}) \mathrm{ppm} ;{ }^{13} \mathrm{C}\left\{{ }^{1} \mathrm{H}\right\}$ NMR (100 MHz, $\left.\mathrm{CDCl}_{3}\right) \delta 142.8,128.2,127.2,127.1,80.9,78.9,32.5,23.5$ ppm; GC-MS $m / z=252\left(\mathrm{M}^{+}\right)$; Anal. Calcd for $\mathrm{C}_{18} \mathrm{H}_{20} \mathrm{O}$ : C, 85.67; H, 7.99. Found: C, 75.48; H, 8.61.

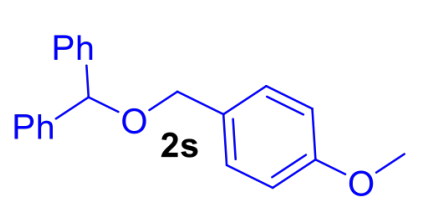

Data for 2s: White solid (65\%, $197 \mathrm{mg}) .{ }^{1} \mathrm{H}$ NMR (400 MHz, $\left.\mathrm{CDCl}_{3}\right) \delta$ 7.13$7.34(\mathrm{~m}, 12 \mathrm{H}), 6.78-6.85(\mathrm{~m}, 2 \mathrm{H}), 5.35(\mathrm{~s}, 1 \mathrm{H}), 4.40(\mathrm{~s}, 2 \mathrm{H}), 3.74(\mathrm{~s}, 3 \mathrm{H}) \mathrm{ppm}$; ${ }^{13} \mathrm{C}\left\{{ }^{1} \mathrm{H}\right\} \mathrm{NMR}\left(100 \mathrm{MHz}, \mathrm{CDCl}_{3}\right) \delta 159.1,142.2,130.4,129.4,128.4,127.4$, 127.1, 113.7, 82.0, 70.1, 55.3 ppm; GC-MS $m / z=304\left(\mathrm{M}^{+}\right) ;{ }^{1} \mathrm{H}$ and ${ }^{13} \mathrm{C} \mathrm{NMR}$ spectral data are in good agreement with the literature data. ${ }^{\mathrm{S} 13}$

Data for 2t: Colorless oil (89\%, $183 \mathrm{mg}) .{ }^{1} \mathrm{H}$ NMR (400 MHz, $\left.\mathrm{CDCl}_{3}\right) \delta 7.27(\mathrm{dd}, J=$

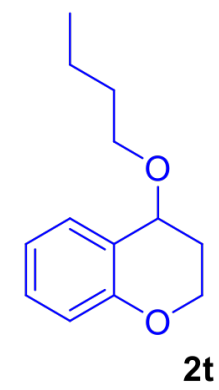
7.6, $1.8 \mathrm{~Hz}, 1 \mathrm{H}), 7.20(\mathrm{ddd}, J=8.4,7.0,1.8 \mathrm{~Hz}, 1 \mathrm{H}), 6.91(\mathrm{td}, J=7.4,1.2 \mathrm{~Hz}, 1 \mathrm{H}), 6.85$ $(\mathrm{dd}, J=8.2,1.2 \mathrm{~Hz}, 1 \mathrm{H}), 4.38(\mathrm{t}, J=3.7 \mathrm{~Hz}, 1 \mathrm{H}), 4.32(\mathrm{td}, J=11.0,3.1 \mathrm{~Hz}, 1 \mathrm{H}), 4.25(\mathrm{dtd}$, $J=11.0,4.1,0.8 \mathrm{~Hz}, 1 \mathrm{H}), 3.59(\mathrm{ttd}, J=15.7,12.9,6.3 \mathrm{~Hz}, 2 \mathrm{H}), 2.10-2.18(\mathrm{~m}, 1 \mathrm{H}), 2.01-$ $2.10(\mathrm{~m}, 1 \mathrm{H}), 1.57-1.66(\mathrm{~m}, 2 \mathrm{H}), 1.37-1.48(\mathrm{~m}, 2 \mathrm{H}), 0.95(\mathrm{t}, J=7.4 \mathrm{~Hz}, 3 \mathrm{H}) \mathrm{ppm} ;{ }^{13} \mathrm{C}\left\{{ }^{1} \mathrm{H}\right\}$ NMR $\left(100 \mathrm{MHz}, \mathrm{CDCl}_{3}\right) \delta 154.7,130.5,29.4,122.2,119.9,116.8,70.3,68.0,62.2,32.1$, 27.6, 19.4, 13.9 ppm; GC-MS $m / z=206\left(\mathrm{M}^{+}\right)$; Anal. Calcd for $\mathrm{C}_{13} \mathrm{H}_{18} \mathrm{O}_{2}$ : C, 75.69; $\mathrm{H}, 8.80$. Found: C, 75.48; H, 8.61.

Data for $2 \mathbf{u}$ : Colorless oil $(82 \%, 178 \mathrm{mg}) .{ }^{1} \mathrm{H}$ NMR $\left(400 \mathrm{MHz}, \mathrm{CDCl}_{3}\right) \delta$ 7.24-7.27 (m,

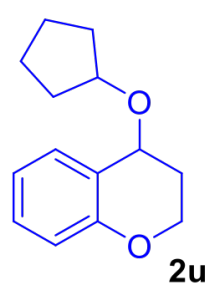
$1 \mathrm{H}), 7.16-7.21(\mathrm{~m}, 1 \mathrm{H}), 6.91(\mathrm{td}, J=7.4,1.2 \mathrm{~Hz}, 1 \mathrm{H}), 6.81-6.85(\mathrm{~m}, 1 \mathrm{H}), 4.48(\mathrm{t}, J=3.9 \mathrm{~Hz}$, $1 \mathrm{H}), 4.28-4.35(\mathrm{~m}, 1 \mathrm{H}), 4.22-4.28(\mathrm{~m}, 1 \mathrm{H}), 4.16-4.22(\mathrm{~m}, 1 \mathrm{H}), 3.88$ (septet, $J=6.1 \mathrm{~Hz}, 1 \mathrm{H})$, 2.04-2.08 (m, 3H), $1.27(\mathrm{~d}, J=6.0 \mathrm{~Hz}, 3 \mathrm{H}), 1.25(\mathrm{~d}, J=6.2 \mathrm{~Hz}, 3 \mathrm{H}) \mathrm{ppm} ;{ }^{13} \mathrm{C}\left\{{ }^{1} \mathrm{H}\right\} \mathrm{NMR}(100$ $\mathrm{MHz}_{\mathrm{CDCl}}$ ) $\delta 154.8,130.2,129.4,122.8,120.2,116.8,68.9,67.4,62.3,28.4,23.3,22.4$ ppm; GC-MS $m / z=192\left(\mathrm{M}^{+}\right)$; Anal. Calcd for $\mathrm{C}_{12} \mathrm{H}_{16} \mathrm{O}_{2}$ : C, 74.97; H, 8.39. Found: C, 75.48; H, 8.61.

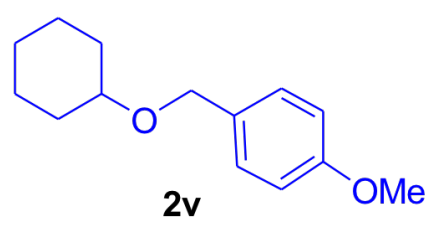

Data for 2v: Colorless oil $(85 \%, 187 \mathrm{mg}) .{ }^{1} \mathrm{H} \mathrm{NMR}\left(400 \mathrm{MHz}, \mathrm{CDCl}_{3}\right) \delta$ $7.24(\mathrm{dd}, J=7.5,1.6 \mathrm{~Hz}, 1 \mathrm{H}), 7.17(\mathrm{td}, J=7.8,1.8 \mathrm{~Hz}, 1 \mathrm{H}), 6.87-6.92(\mathrm{~m}, 1 \mathrm{H})$, 6.79-6.83 (m, 1H), $4.43(\mathrm{t}, J=4.0 \mathrm{~Hz}, 1 \mathrm{H}), 4.41-4.45(\mathrm{~m}, 1 \mathrm{H}), 4.36-4.16(\mathrm{~m}$, $4 \mathrm{H}), 1.93-2.12(\mathrm{~m}, 2 \mathrm{H}), 1.67(\mathrm{~m}, 1 \mathrm{H}), 1.63-1.88(\mathrm{~m}, 5 \mathrm{H}), 1.51-1.63(\mathrm{~m}, 2 \mathrm{H})$ ppm; ${ }^{13} \mathrm{C}\left\{{ }^{1} \mathrm{H}\right\}$ NMR $\left(100 \mathrm{MHz}, \mathrm{CDCl}_{3}\right) \delta 154.8,130.3,129.2,122.8,120.1$, 
116.8, 78.5, 77.4, 68.0, 62.4, 33.0, 32.8, 28.1, 23.6, 23.4 ppm; GC-MS $m / z=218\left(\mathrm{M}^{+}\right)$; Anal. Calcd for $\mathrm{C}_{14} \mathrm{H}_{20} \mathrm{O}_{2}$ : C, 76.33; H, 9.15. Found: C, 76.38; H, 9.13.

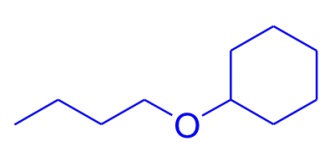

$2 \mathbf{w}$

Data for 2w: Colorless liquid (80\%, $124 \mathrm{mg}) .{ }^{1} \mathrm{H}$ NMR (400 MHz, $\left.\mathrm{CDCl}_{3}\right) \delta 3.43$ $(\mathrm{t}, J=6.7 \mathrm{~Hz}, 2 \mathrm{H}), 3.13-3.23(\mathrm{~m}, 1 \mathrm{H}), 1.80-1.95(\mathrm{~m}, 3 \mathrm{H}), 1.66-1.77$ (m, 3H), 1.47-1.57 $(\mathrm{m}, 3 \mathrm{H}), 1.31-1.42(\mathrm{~m}, 2 \mathrm{H}), 1.14-1.31(\mathrm{~m}, 6 \mathrm{H}), 0.91(\mathrm{t}, J=7.4 \mathrm{~Hz}, 3 \mathrm{H}) \mathrm{ppm} ;{ }^{13} \mathrm{C}\left\{{ }^{1} \mathrm{H}\right\}$ NMR $\left(100 \mathrm{MHz}, \mathrm{CDCl}_{3}\right) \delta 77.4,67.5,32.3,32.3,25.8,25.8,24.2,19.4,13.9$ ppm; GCMS $m / z=156\left(\mathrm{M}^{+}\right) ;{ }^{1} \mathrm{H}$ and ${ }^{13} \mathrm{C}$ NMR spectral data are in good agreement with the literature data. ${ }^{\text {S7 }}$

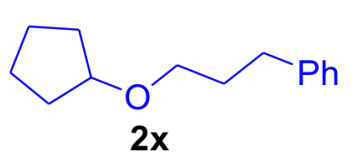

Data for 2x: Yellow liquid $(98 \%, 199 \mathrm{mg}) .{ }^{1} \mathrm{H}$ NMR $\left(400 \mathrm{MHz}, \mathrm{CDCl}_{3}\right) \delta$ 7.25$7.32(\mathrm{~m}, 2 \mathrm{H}), 7.17-7.23(\mathrm{~m}, 3 \mathrm{H}), 4.28-4.35(\mathrm{~m}, 1 \mathrm{H}), 3.65(\mathrm{t}, J=6.8 \mathrm{~Hz}, 2 \mathrm{H}), 2.70(\mathrm{t}, J$ $=7.7 \mathrm{~Hz}, 2 \mathrm{H}), 1.94-2.04(\mathrm{~m}, 2 \mathrm{H}), 1.84-1.93(\mathrm{~m}, 2 \mathrm{H}), 1.68-1.82(\mathrm{~m}, 4 \mathrm{H}), 1.48-1.65(\mathrm{~m}$, 2H) ppm; ${ }^{13} \mathrm{C}\left\{{ }^{1} \mathrm{H}\right\}$ NMR $\left(100 \mathrm{MHz}, \mathrm{CDCl}_{3}\right) \delta 141.8,128.4,128.4,128.4,128.3,128.3,128.3,125.8,73.9,62.1$, 35.4, 34.1, 32.0, $23.2 \mathrm{ppm}$; GC-MS $m / z=234\left(\mathrm{M}^{+}\right) ;{ }^{1} \mathrm{H}$ and ${ }^{13} \mathrm{C}$ NMR spectral data are in good agreement with the literature data. ${ }^{\mathrm{S} 14}$

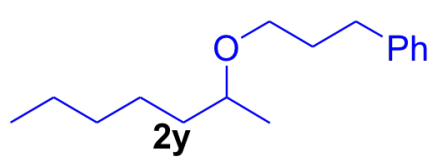

Data for 2y: Colorless oil $(55 \%, 128 \mathrm{mg}) .{ }^{1} \mathrm{H}$ NMR $\left(400 \mathrm{MHz}, \mathrm{CDCl}_{3}\right)$ 7.17-7.24 (m, 3H), 7.08-7.15 (m, 2H), $3.42(\mathrm{dt}, J=9.1,6.4 \mathrm{~Hz}, 2 \mathrm{H}), 3.23-3.31$ $(\mathrm{m}, 2 \mathrm{H}), 2.63(\mathrm{td}, J=7.8,1.8 \mathrm{~Hz}, 2 \mathrm{H}), 1.76-1.85(\mathrm{~m}, 2 \mathrm{H}), 1.39-1.52(\mathrm{~m}, 1 \mathrm{H})$, 1.16-1.35 (m, 6H), $1.05(\mathrm{~d}, J=5.9 \mathrm{~Hz}, 3 \mathrm{H}), 0.82(\mathrm{t}, J=6.8 \mathrm{~Hz}, 3 \mathrm{H}) \mathrm{ppm}$; ${ }^{13} \mathrm{C}\left\{{ }^{1} \mathrm{H}\right\}$ NMR $\left(100 \mathrm{MHz}, \mathrm{CDCl}_{3}\right) \delta 142.2,128.5,128.3,125.7,75.4,67.43,36.7,32.5,32.0,31.7,25.3,22.7$, 19.7, 14.1 ppm; GC-MS m/z=234 (M+); Anal. Calcd for $\mathrm{C}_{16} \mathrm{H}_{26} \mathrm{O}: \mathrm{C}, 81.99 ; \mathrm{H}, 11.18$. Found: C, 75.48; H, 8.61.

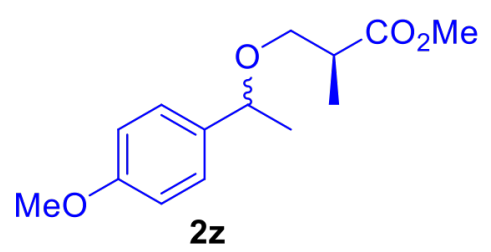

Data for $\mathbf{2 z}$ (1:1 diasteromers): White solid $(78 \%, 196 \mathrm{mg})$. Isomer $\mathbf{A}$ : ${ }^{1} \mathrm{H}$ NMR $\left(400 \mathrm{MHz}, \mathrm{CDCl}_{3}\right) \delta 7.21(\mathrm{~d}, J=8.8 \mathrm{~Hz}, 2 \mathrm{H}), 6.87(\mathrm{~d}, J=8.8 \mathrm{~Hz}$, $2 \mathrm{H}), 4.35(\mathrm{q}, J=6.3 \mathrm{~Hz}, 1 \mathrm{H}), 3.80(\mathrm{~s}, 3 \mathrm{H}), 3.67(\mathrm{~s}, 3 \mathrm{H}), 3.46(\mathrm{t}, J=9.3 \mathrm{~Hz}$, $1 \mathrm{H}), 3.28(\mathrm{t}, J=6.4 \mathrm{~Hz}, 1 \mathrm{H}), 2.78-2.66(\mathrm{~m}, 1 \mathrm{H}), 1.38(\mathrm{~d}, J=6.3 \mathrm{~Hz}, 3 \mathrm{H}), 1.14$ $(\mathrm{d}, J=7.0 \mathrm{~Hz}, 3 \mathrm{H}) \mathrm{ppm} ;{ }^{13} \mathrm{C}\left\{{ }^{1} \mathrm{H}\right\} \mathrm{NMR}\left(100 \mathrm{MHz}, \mathrm{CDCl}_{3}\right) \delta 175.5,143.7$, 128.3, 127.4, 126.1, 78.5, 70.5, 51.7, 40.3, 24.1, 14.0 ppm. Isomer B: ${ }^{1} \mathrm{H}$ NMR $\left(100 \mathrm{MHz}, \mathrm{CDCl}_{3}\right) \delta 7.20(\mathrm{~d}, J$ $=8.8 \mathrm{~Hz}, 2 \mathrm{H}), 6.87(\mathrm{~d}, J=8.8 \mathrm{~Hz}, 2 \mathrm{H}), 4.34(\mathrm{q}, J=6.3 \mathrm{~Hz}, 1 \mathrm{H}), 3.80(\mathrm{~s}, 3 \mathrm{H}), 3.68(\mathrm{~s}, 3 \mathrm{H}), 3.48(\mathrm{t}, J=9.3 \mathrm{~Hz}$, $1 \mathrm{H}), 3.30(\mathrm{t}, J=6.4 \mathrm{~Hz}, 1 \mathrm{H}), 2.78-2.66(\mathrm{~m}, 1 \mathrm{H}), 1.39(\mathrm{~d}, J=6.3 \mathrm{~Hz}, 3 \mathrm{H}), 1.12(\mathrm{~d}, J=7.0 \mathrm{~Hz}, 3 \mathrm{H}) \mathrm{ppm}$; ${ }^{13} \mathrm{C}\left\{{ }^{1} \mathrm{H}\right\}$ NMR $\left(100 \mathrm{MHz}, \mathrm{CDCl}_{3}\right) \delta 175.3,143.7,128.4,127.4,126.1,78.2,70.4,51.7,40.3,24.1,14.0$ ppm; GC-MS $m / z=252\left(\mathrm{M}^{+}\right) ;{ }^{1} \mathrm{H}$ and ${ }^{13} \mathrm{C}$ NMR spectral data are in good agreement with the literature data. ${ }^{\mathrm{S} 15}$

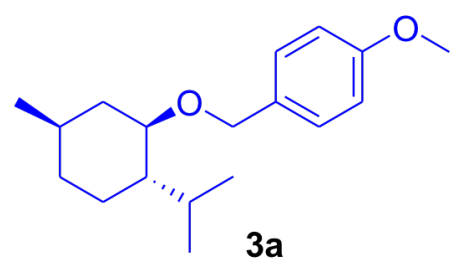

Data for 3a: Colorless oil $(90 \%, 248 \mathrm{mg}) .{ }^{1} \mathrm{H}$ NMR (400 MHz, $\left.\mathrm{CDCl}_{3}\right) \delta$ 7.26-7.33 (m, 2H), 6.87-6.92 (m, 2H), 4.61 (d, $J=11.0 \mathrm{~Hz}, 1 \mathrm{H}), 4.35$ (d, $J=$ $11.0 \mathrm{~Hz}, 1 \mathrm{H}), 3.81$ (s, 3H), 3.17 (td, $J=10.5,4.2 \mathrm{~Hz}, 1 \mathrm{H}), 2.31$ (m, $J=2.7 \mathrm{~Hz}$, $1 \mathrm{H}), 2.20(\mathrm{~m}, J=1.7 \mathrm{~Hz}, 1 \mathrm{H}), 1.60-1.71(\mathrm{~m}, 2 \mathrm{H}), 1.39(\mathrm{~s}, 2 \mathrm{H}), 0.95-0.98(\mathrm{~m}$, 
$6 \mathrm{H}), 0.92(\mathrm{~d}, J=7.1 \mathrm{~Hz}, 3 \mathrm{H}), 0.73(\mathrm{~d}, J=6.9 \mathrm{~Hz}, 3 \mathrm{H}) \mathrm{ppm} ;{ }^{13} \mathrm{C}\left\{{ }^{1} \mathrm{H}\right\} \mathrm{NMR}\left(100 \mathrm{MHz}, \mathrm{CDCl}_{3}\right) \delta 158.9,131.2$, $129.3,113.6,78.3,70.0,55.1,48.2,40.2,34.5,31.5,25.4,23.2,22.3,21.0,14.0$ ppm; GC-MS $m / z=276\left(\mathrm{M}^{+}\right)$; ${ }^{1} \mathrm{H}$ and ${ }^{13} \mathrm{C}$ NMR spectral data are in good agreement with the literature data. ${ }^{\mathrm{S} 16}$

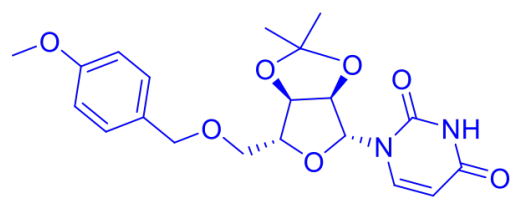

$3 b$

Data for 3b: Yellow solid (52\%, $210 \mathrm{mg}) .{ }^{1} \mathrm{H}$ NMR (400 MHz, $\mathrm{CDCl}_{3}$ ) ठ 8.79 (br s, 1H), 7.59 (d, $J=8.1 \mathrm{~Hz}, 1 \mathrm{H}), 7.23$ (d, $J=8.9 \mathrm{~Hz}, 2 \mathrm{H}), 6.90$ (d, $J=8.7 \mathrm{~Hz}, 2 \mathrm{H}), 5.96(\mathrm{~d}, J=2.8 \mathrm{~Hz}, 1 \mathrm{H}), 5.52(\mathrm{dd}, J=8.1,2.3 \mathrm{~Hz}, 1 \mathrm{H})$, $4.81(\mathrm{dd}, J=6.2,2.9 \mathrm{~Hz}, 1 \mathrm{H}), 4.7(\mathrm{dd}, J=6.2,2.8 \mathrm{~Hz}, 1 \mathrm{H}), 4.47$ (dd, $J=$ $14.3,11.1 \mathrm{~Hz}, 2 \mathrm{H}), 4.40(\mathrm{dd}, J=5.6,2.9 \mathrm{~Hz}, 1 \mathrm{H}), 3.82(\mathrm{~s}, 3 \mathrm{H}), 3.76(\mathrm{dd}, J=$ 10.5, $2.6 \mathrm{~Hz}, 1 \mathrm{H}), 3.65(\mathrm{dd}, J=10.5,3.4 \mathrm{~Hz}, 1 \mathrm{H}), 1.59$ (s, 3H), 1.35 (s, 3H) ppm; ${ }^{13} \mathrm{C} \mathrm{NMR}\left(100 \mathrm{MHz} \mathrm{CDCl}_{3}\right)$ $163.5,159.4,150.2$, 141.1, 129.5, 129.1, 114.0, 113.8, 102.1, 92.3, 85.5, 84.9, 80.8, 73.2, 69.7, 55.2, 27.1, 25.2 ppm; HRMS (ESI): calcd for $\mathrm{C}_{20} \mathrm{H}_{24} \mathrm{~N}_{2} \mathrm{O}_{7}\left([\mathrm{M}+\mathrm{H}]^{+}\right)$405.1656, found 405.1658. ${ }^{1} \mathrm{H}$ and ${ }^{13} \mathrm{C}$ NMR spectral data are in good agreement with the literature data. ${ }^{\mathrm{S} 17}$

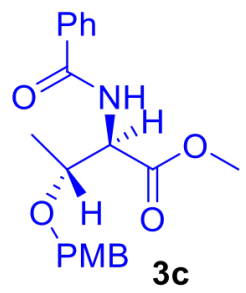

Data for 3c: White Crystal (84\%, $299 \mathrm{mg}) .{ }^{1} \mathrm{H} \mathrm{NMR}\left(400 \mathrm{MHz}, \mathrm{CDCl}_{3}\right) \delta$ 7.79-7.86 (m, 2H), 7.46-7.52 (m, 1H), 7.38-7.45 (m, 2H), 7.17-7.22 (m, 2H), 6.84-6.89 (m, 3H), 4.87 $(\mathrm{dd}, J=9.1,2.4 \mathrm{~Hz}, 1 \mathrm{H}), 4.54(\mathrm{~d}, J=11.5 \mathrm{~Hz}, 1 \mathrm{H}), 4.34(\mathrm{~d}, J=11.5 \mathrm{~Hz}, 1 \mathrm{H}), 4.20$ (ddd, $J$ $=12.6,6.3,2.4 \mathrm{~Hz}, 1 \mathrm{H}), 3.78(\mathrm{~d}, J=0.4 \mathrm{~Hz}, 3 \mathrm{H}), 3.68(\mathrm{~s}, 3 \mathrm{H}), 1.26(\mathrm{~d}, J=6.2 \mathrm{~Hz}, 3 \mathrm{H})$ ppm; ${ }^{13} \mathrm{C}\left\{{ }^{1} \mathrm{H}\right\}$ NMR $\left(100 \mathrm{MHz}, \mathrm{CDCl}_{3}\right) \delta 171.0,167.5,159.2,133.7,131.6,129.7,129.3$, 128.4, 127.0, 113.6, 73.7, 70.3, 56.9, 55.1, 52.2, 16.2 ppm; HRMS (ESI): calcd for $\mathrm{C}_{20} \mathrm{H}_{23} \mathrm{NO}_{5}\left([\mathrm{M}+\mathrm{Na}]^{+}\right)$ 380.1668 , found 380.1669 .

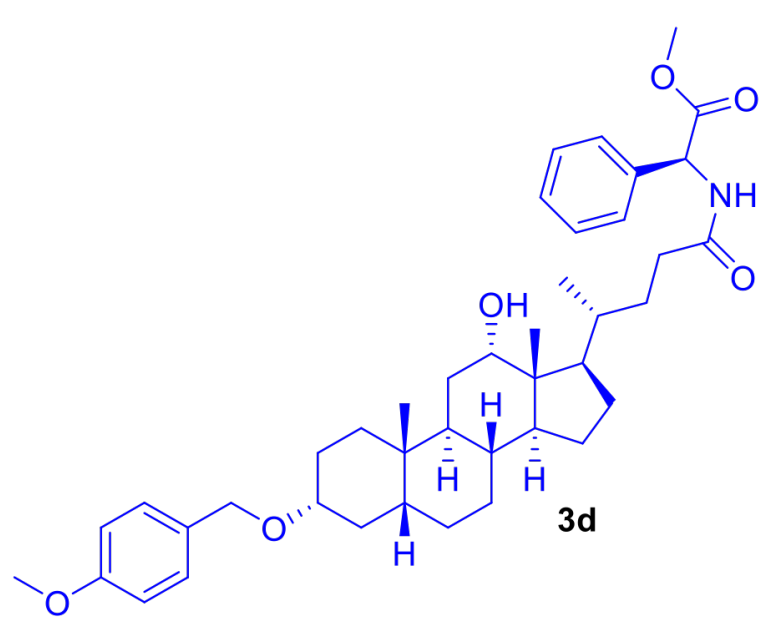

Data for 3d: Yellow solid $(81 \%, 533 \mathrm{mg}) .{ }^{1} \mathrm{H}$ NMR $\left(400 \mathrm{MHz}, \mathrm{CDCl}_{3}\right) \delta$ 7.33-7.42 (m, 5H), $7.30(\mathrm{~d}, J=8.9 \mathrm{~Hz}$, 2H), $6.90(\mathrm{~d}, J=7.8 \mathrm{~Hz}, 2 \mathrm{H}), 6.69$ (d, $J=7.2 \mathrm{~Hz}, 1 \mathrm{H}), 5.65$ (d, $J=6.7 \mathrm{~Hz}, 1 \mathrm{H}), 4.50-4.53(\mathrm{~m}, 2 \mathrm{H}), 3.97$ (br s, 1H), 3.83 (s, 3H), 3.75 (s, 3H), 3.39 (tt, $J=11.0,4.4 \mathrm{~Hz}, 1 \mathrm{H}), 2.30-2.42$ (m, 1H), 1.04-1.94 (m, 24H), 0.95-1.02 (m, 4H), 0.94 (s, 3H), 0.68 (s, 3H) ppm; ${ }^{13} \mathrm{C}\left\{{ }^{1} \mathrm{H}\right\}$ NMR $\left(100 \mathrm{MHz}, \mathrm{CDCl}_{3}\right) \delta 172.8$, $171.4,158.8,136.5,131.0,128.9,128.8,128.3,127.1,113.6$, 78.1, 72.9, 69.2, 56.12, 55.1, 52.6, 48.0, 46.9, 46.3, 41.9, 35.9,

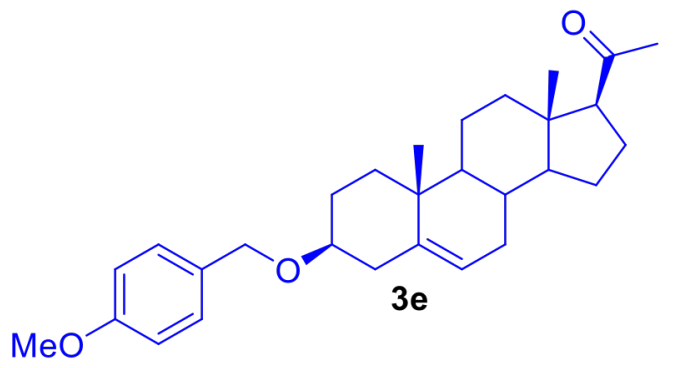
$35.1,34.9,34.3,33.4,33.0,32.8,31.1,28.5,27.3,27.1,26.9$, 25.9, 23.5, 23.1, 17.2, 12.6 ppm; HRMS (ESI): calcd for $\mathrm{C}_{41} \mathrm{H}_{57} \mathrm{NO}_{6}\left([\mathrm{M}+\mathrm{H}]^{+}\right) 660.4259$, found 660.4262 .

Data for 3e: White crystalline solid $(78 \%, 340 \mathrm{mg}) .{ }^{1} \mathrm{H}$ 
NMR (400 MHz, $\left.\mathrm{CDCl}_{3}\right) \delta$ 7.22-7.30 (m, 2H), 6.81-6.90 (m, 2H), 5.29-5.37 (m, 1H), $4.48(\mathrm{~s}, 2 \mathrm{H}), 3.78(\mathrm{~s}, 3 \mathrm{H})$, 3.19-3.31 (m, 1H), 2.47-2.56 (m, 1H), 2.35-2.45 (m, 1H), 2.12-2.30 (m, 2H), $2.11(\mathrm{~s}, 3 \mathrm{H}), 1.77-2.06(\mathrm{~m}, 4 \mathrm{H})$, 1.37-1.72 (m, 9H), 1.01-1.31 (m, 3H), $1.00(\mathrm{~s}, 3 \mathrm{H}), 0.61(\mathrm{~s}, 3 \mathrm{H})$ ppm; ${ }^{13} \mathrm{C} \mathrm{NMR}\left(100 \mathrm{MHz}, \mathrm{CDCl}_{3}\right) 209.4,58.9$, 140.9, 131.0, 129.0, 121.1, 113.7, 78.0, 69.5, 63.6, 56.8, 55.2, 49.9, 43.9, 39.0, 38.7, 37.2, 36.8, 31.7, 31.7, 31.5, 28.3, 24.4, 22.7, 21.0, 19.3, $13.1 \mathrm{ppm}$; GC-MS $m / z=276 .{ }^{1} \mathrm{H}$ and ${ }^{13} \mathrm{C}$ NMR spectral data are in good agreement with the literature data. ${ }^{\mathrm{S} 18}$

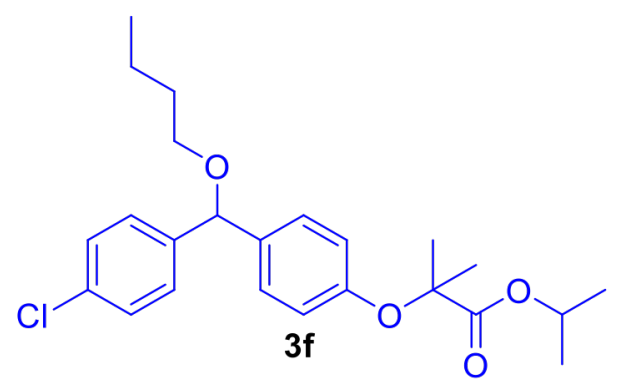

Data for 3f: White solid (73\%, $305 \mathrm{mg}) .{ }^{1} \mathrm{H}$ NMR (400 MHz, $\left.\mathrm{CDCl}_{3}\right) \delta$ 7.23-7.31 (m, 4H), 7.12-7.20 (m, 2H), 6.77-6.85 (m, 2H), 5.25 (s, 1H), 5.08 (septet, $J=6.2 \mathrm{~Hz}, 1 \mathrm{H}), 3.60$ (dt, $J=9.3,6.6 \mathrm{~Hz}$, $1 \mathrm{H}), 1.52-1.66(\mathrm{~m}, 9 \mathrm{H}), 1.34-1.47(\mathrm{~m}, 2 \mathrm{H}), 1.20(\mathrm{~d}, J=6.5 \mathrm{~Hz}$, $6 \mathrm{H}), 0.93$ (t, $J=7.8 \mathrm{~Hz}, 3 \mathrm{H}) \mathrm{ppm} ;{ }^{13} \mathrm{C} \mathrm{NMR}\left(100 \mathrm{MHz}, \mathrm{CDCl}_{3}\right.$ ) $173.6,154.9,141.3,135.4,128.3,128.2,127.7,118.6,102.8,82.3$, 78.9, 68.8, 65.0, 35.5, 31.9, 25.3, 21.4, 19.4, 18.0, 13.8 ppm; GCMS $m / z=418$; HRMS (APCI): calcd for $\mathrm{C}_{24} \mathrm{H}_{31} \mathrm{ClO}_{4}\left([\mathrm{M}+\mathrm{H}]^{+}\right) 419.1989$, found 419.1991.

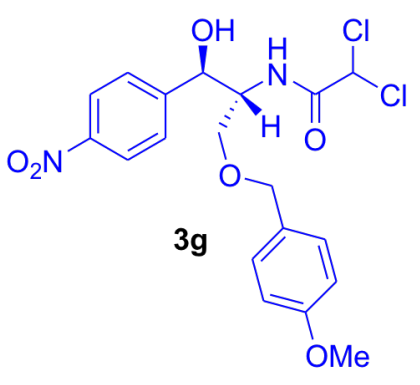

Data for 3g: White solid (65\%, $287 \mathrm{mg}) .{ }^{1} \mathrm{H}$ NMR $\left(400 \mathrm{MHz}, \mathrm{CDCl}_{3}\right) \delta$ 8.02-8.13 (m, $2 \mathrm{H}), 7.42(\mathrm{~d}, J=8.7 \mathrm{~Hz}, 2 \mathrm{H}), 7.18$ (d, $J=8.7 \mathrm{~Hz}, 2 \mathrm{H}), 7.09$ (d, $J=$ $9.0 \mathrm{~Hz}, 1 \mathrm{H}), 6.83$ (d, $J=8.5 \mathrm{~Hz}, 2 \mathrm{H}), 5.70$ (s, 1H), 5.13 (d, $J=2.4 \mathrm{~Hz}, 1 \mathrm{H}), 4.44$ $(\mathrm{s}, 2 \mathrm{H}), 4.12-4.19(\mathrm{~m}, 1 \mathrm{H}), 3.73(\mathrm{~s}, 3 \mathrm{H}), 3.60-3.69(\mathrm{~m}, 3 \mathrm{H}) \mathrm{ppm} ;{ }^{13} \mathrm{C}\left\{{ }^{1} \mathrm{H}\right\} \mathrm{NMR}$ $\left(100 \mathrm{MHz}, \mathrm{CDCl}_{3}\right) \delta 164.1,159.6,147.5,129.6,128.7,126.7,123.5,114.0,73.5$, 73.3, 70.4, 66.1, 55.3, 54.4 ppm; GC-MS $m / z=442\left(\mathrm{M}^{+}\right)$; HRMS (APCI): calcd for $\mathrm{C}_{19} \mathrm{H}_{22} \mathrm{Cl}_{2} \mathrm{~N}_{2} \mathrm{O}_{6}\left([\mathrm{M}+\mathrm{H}]^{+}\right)$443.0777; found. 443.0779.

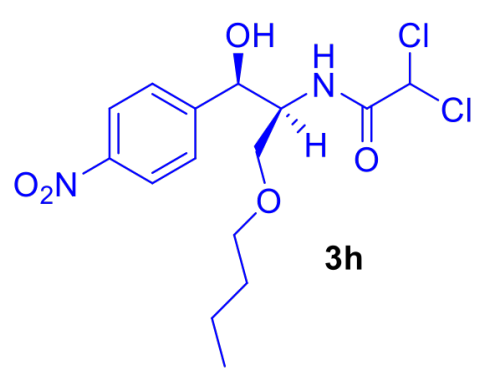

Data for 3h: Colorless oil $(72 \%, 272 \mathrm{mg}) .{ }^{1} \mathrm{H}$ NMR (400 MHz, $\left.\mathrm{CDCl}_{3}\right)$ d 8.17-8.23 (m, 2H), 7.50-7.55 (m, 2H), $7.08(\mathrm{~d}, J=9.7 \mathrm{~Hz}, 1 \mathrm{H}), 5.68(\mathrm{~s}, 1 \mathrm{H})$, $5.08-5.13(\mathrm{~m}, 1 \mathrm{H}), 4.88(\mathrm{t}, J=5.0 \mathrm{~Hz}, 1 \mathrm{H}), 4.32(\mathrm{dq}, J=9.7,1.8 \mathrm{~Hz}, 1 \mathrm{H})$, 4.08-4.20 (m, 3H), 1.76-1.85 (m, 3H), 1.49-1.61 (m, 2H), $1.01(\mathrm{t}, J=7.3 \mathrm{~Hz}$, $3 \mathrm{H})$ ppm; ${ }^{13} \mathrm{C}\left\{{ }^{1} \mathrm{H}\right\}$ NMR $\left(100 \mathrm{MHz}, \mathrm{CDCl}_{3}\right) \delta 163.5,147.5,144.4,126.4$, $126.4,123.5,123.4,102.9,78.4,77.4,77.3,76.7,76.6,70.2,65.9,47.6,36.7$, 17.0, 14.0 ppm; GC-MS $m / z=379\left(\mathrm{M}^{+}\right)$; HRMS (APCI): calcd for $\mathrm{C}_{15} \mathrm{H}_{21} \mathrm{Cl}_{2} \mathrm{~N}_{2} \mathrm{O}_{5}$

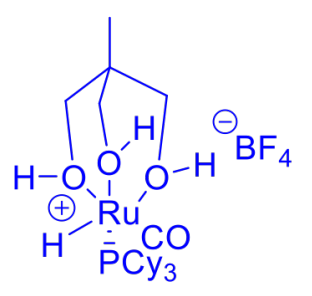

$4 c$ $\left([\mathrm{M}+\mathrm{H}]^{+}\right)$379.0828; found. 379.0825.

Data for 4c: Complex 1 (115 $\mathrm{mg}, \quad 0.2 \mathrm{mmol})$ and 1,1,1tris(hydroxymethyl)ethane $(24 \mathrm{mg}, 0.2 \mathrm{mmol})$ in acetone $(2 \mathrm{~mL})$ were stirred at room temperature for $30 \mathrm{~min}$. Crystallization in acetone $/ n$-pentane to obtain the complex as white crystals in $80 \%$ yield. ${ }^{1} \mathrm{H}$ NMR (400 MHz, acetone- $\left.d_{6}\right) \delta 3.64(\mathrm{~m}, 3 \mathrm{H}), 3.48-$ 
$3.55(\mathrm{~m}, 6 \mathrm{H}), 1.17-1.39(\mathrm{~m}, 33 \mathrm{H}), 0.82(\mathrm{~s}, 3 \mathrm{H}),-17.76\left(\mathrm{~d}, J_{\mathrm{PH}}=34.2 \mathrm{~Hz}, 1 \mathrm{H}\right) \mathrm{ppm} ;{ }^{13} \mathrm{C}\left\{{ }^{1} \mathrm{H}\right\} \mathrm{NMR}(100 \mathrm{MHz}$ $\left.\mathrm{CDCl}_{3}\right) \delta 216.1\left(\mathrm{~d}, J_{\mathrm{CP}}=18.3 \mathrm{~Hz}\right), 72.0,65.7,64.5,37.5,30.8,30.1,27.9,27.8,26.7 \mathrm{ppm} ;{ }^{31} \mathrm{P} \mathrm{NMR}(100 \mathrm{MHz}$ $\left.\mathrm{CDCl}_{3}\right) \delta 76.4$ ppm; FT-IR (pure solid) $v_{\mathrm{CO}}=1915 \mathrm{~cm}^{-1}$. 


\section{References}

S1 Dimitriadis, E.; Massy-Westropp, R. A. Aust. J. Chem. 1984, 37, 619-627.

S2 Yu, J.-L.; Wang, H.; Zou, K.-F.; Zhang, J.-R.; Gao, X.; Zhang, D.-W.; Li, Z.-T. Tetrahedron 2013, $69,310-315$.

S3 Molander, G. A.; Canturk, B. Org. Lett. 2008, 10, 2135-2138.

S4 Burke, C. P.; Haq, N.; Boger, D. L. J. Am. Chem. Soc. 2010, 132, 2157-2159.

S5 Joseph, M.; Jacobsen, E. N. J. Am. Chem. Soc. 2001, 123, 2687-2688.

S6 Shah, S. T. A.; Singh, P. S.; Guiry J. J. Org. Chem. 2009, 74, 2179-2182.

S7 Radhakrishnan, S.; Franken, J.; Martens, J. A. Green Chem. 2012, 14, 1475-1479.

S8 Sassaman, M. B.; Kotian, K. D.; Prakash, G. K. S.; Olah, G. A. J. Org. Chem. 1987, 52, 4314-4319.

S9 Wang, H. Chinese J. Chem. 2011, 29, 1180-1184.

S10 Zaccheria, F.; Psaro, R.; Ravasio, N. Tetrahedron Lett. 2009, 50, 5221-5224.

S11 Talluri, S. K.; Sudalai, A. Org. Lett. 2005, 7, 855-857.

S12 Davies, T. E.; Kean, J. R.; Apperley, D. C.; Taylor, S. H.; Graham, A. E. ACS Sust. Chem. Eng. 2014, 2, 860-866.

S13 Yadav, J. S.; Meshram, H. M.; Reddy, G. S.; Sumithra, G. Tetrahedron Lett. 1998, 39, 3043-3046.

S14 Huang, H.; Nelson, C. G.; Taber, D. F. Tetrahedron Lett. 2010, 51, 3545-3546.

S15 Kim, J.; Lee, D.-H.; Kalutharage, N.; Yi, C. S. ACS Catal. 2014, 4, 3881-3885.

S16 Shintou, T.; Mukaiyama, T. J. Am. Chem. Soc. 2004, 126, 7359-7367.

S17 Blank, H. U.; Pfleiderer, W. Justus Liebigs Ann. Chem. 1970, 742, 1-15.

S18 Piazza, P. V.; Vallee, M.; Felpin, F.-X.; Revest, J.-M.; Fabre, S. PCT Int. Appl. 2014, WO2014083068 A1 20140605. 


\section{8. ${ }^{1} \mathrm{H}$ and ${ }^{13} \mathrm{C}\left\{{ }^{1} \mathrm{H}\right\}$ NMR Spectra of New Compounds}
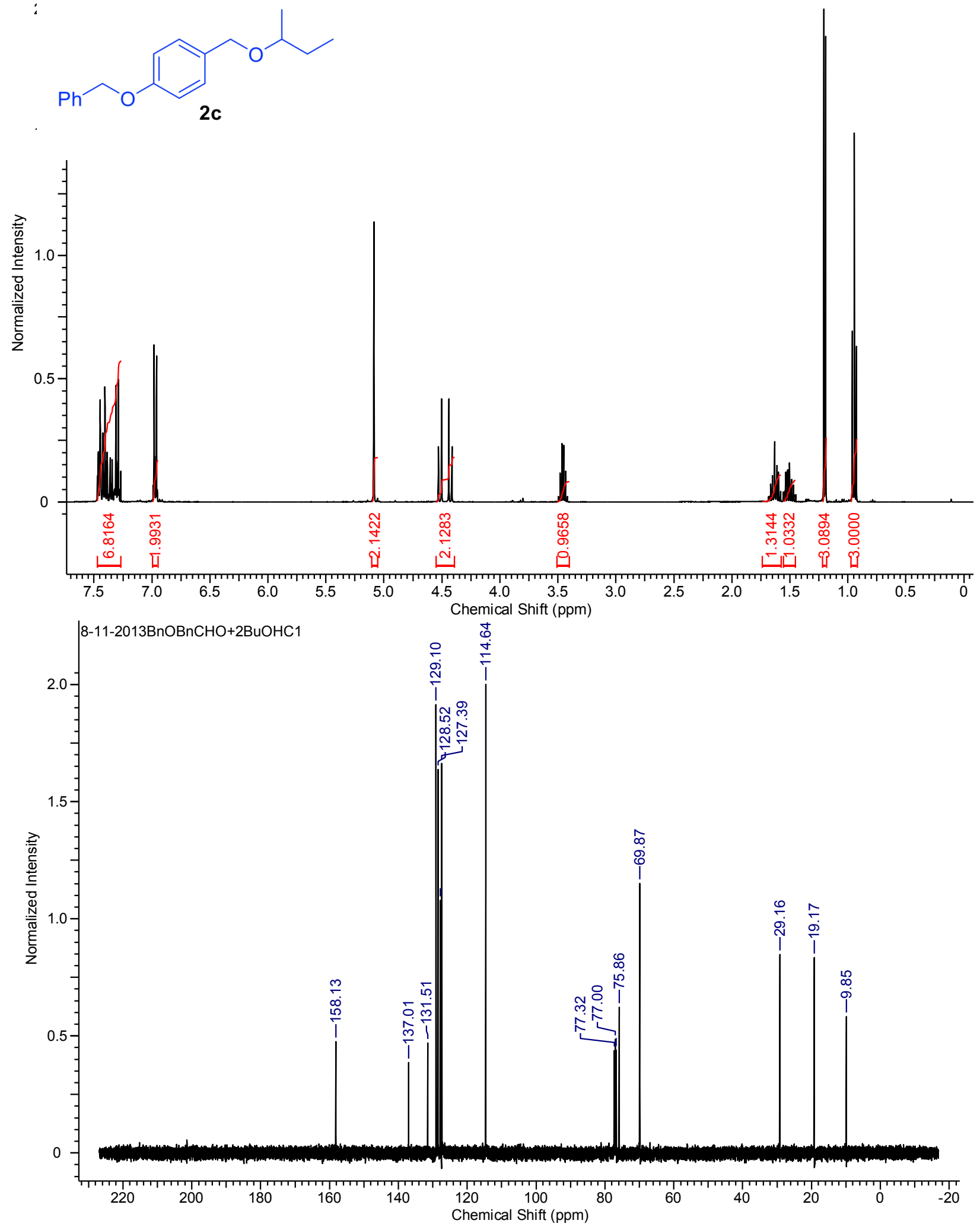

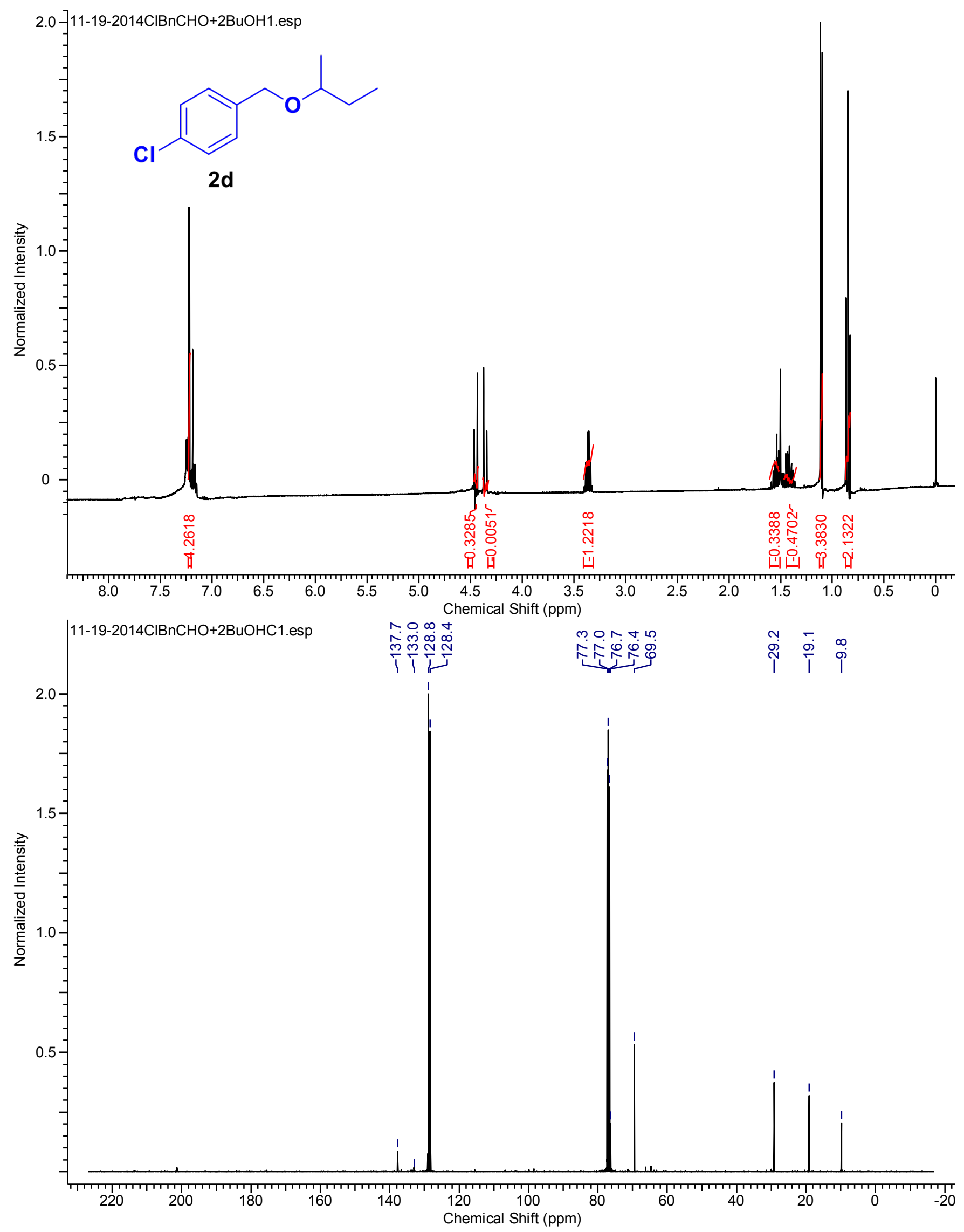

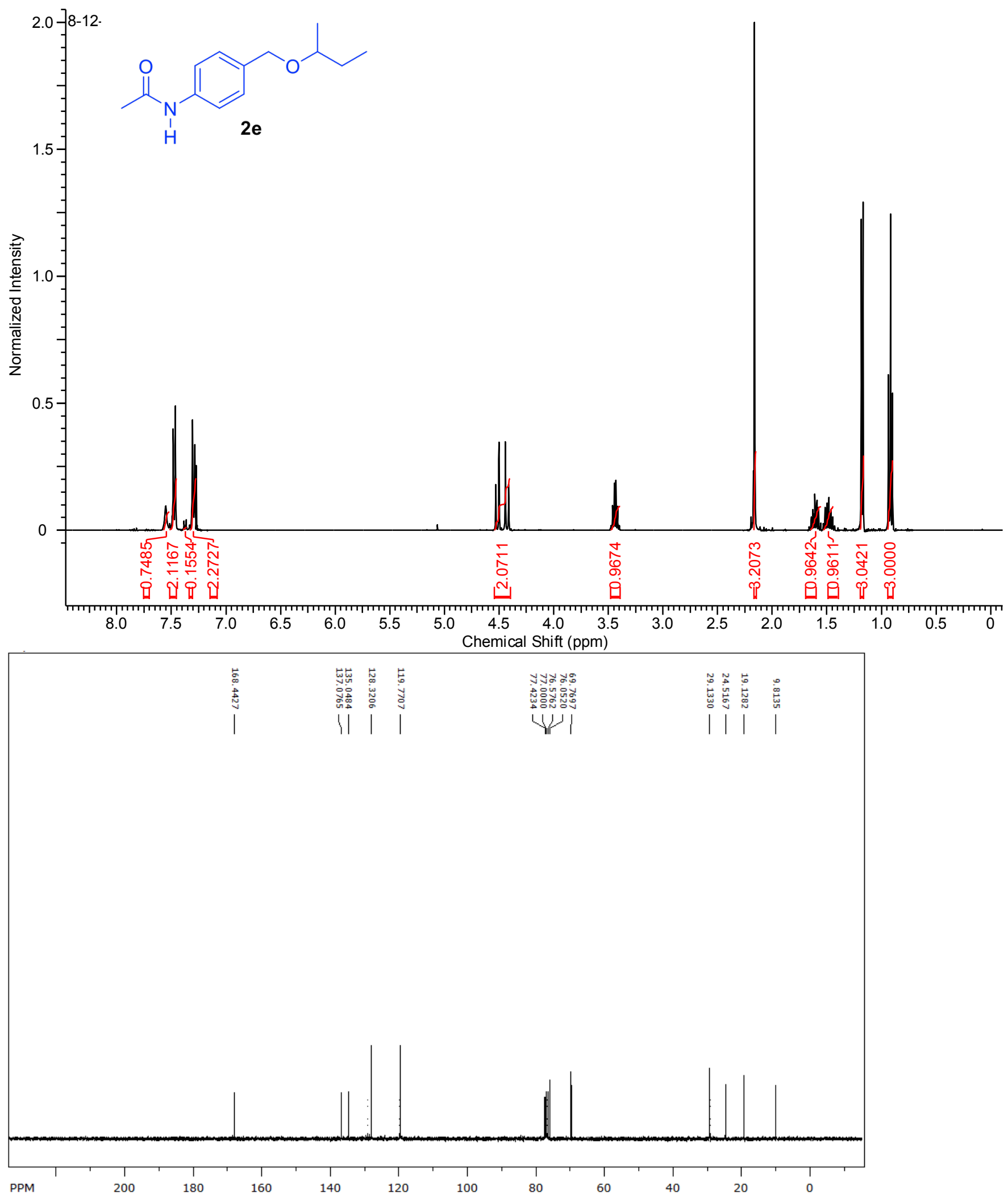

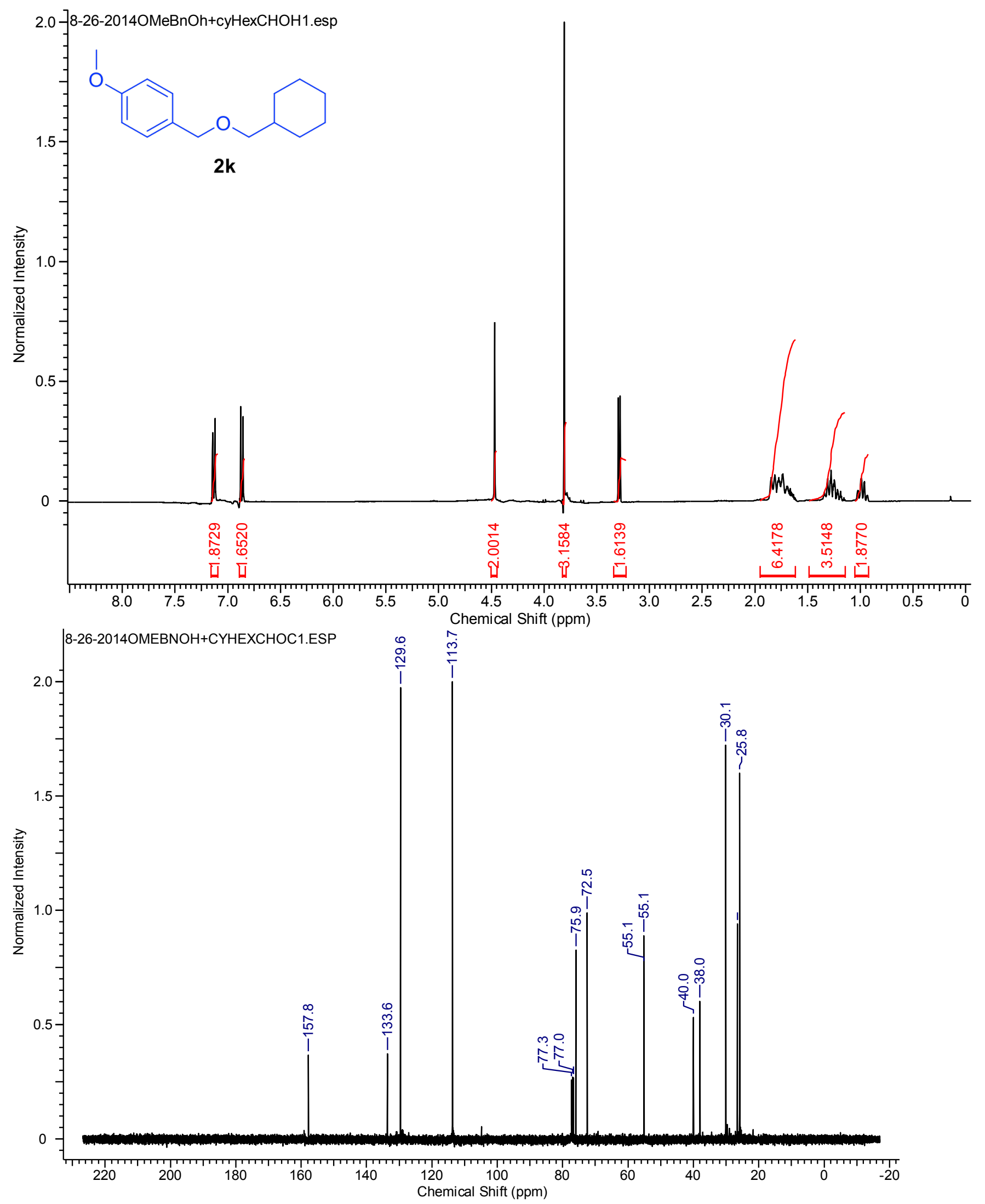

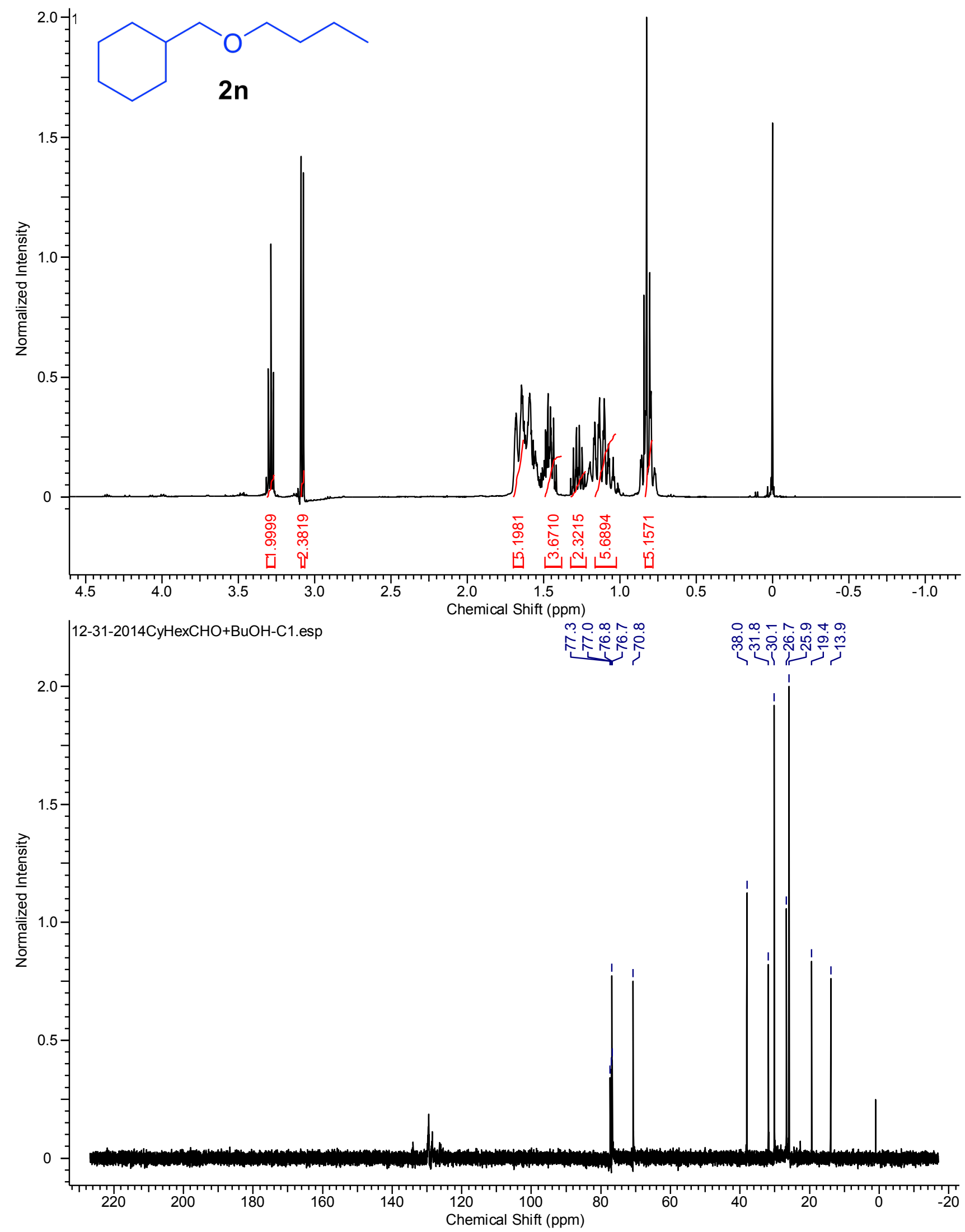

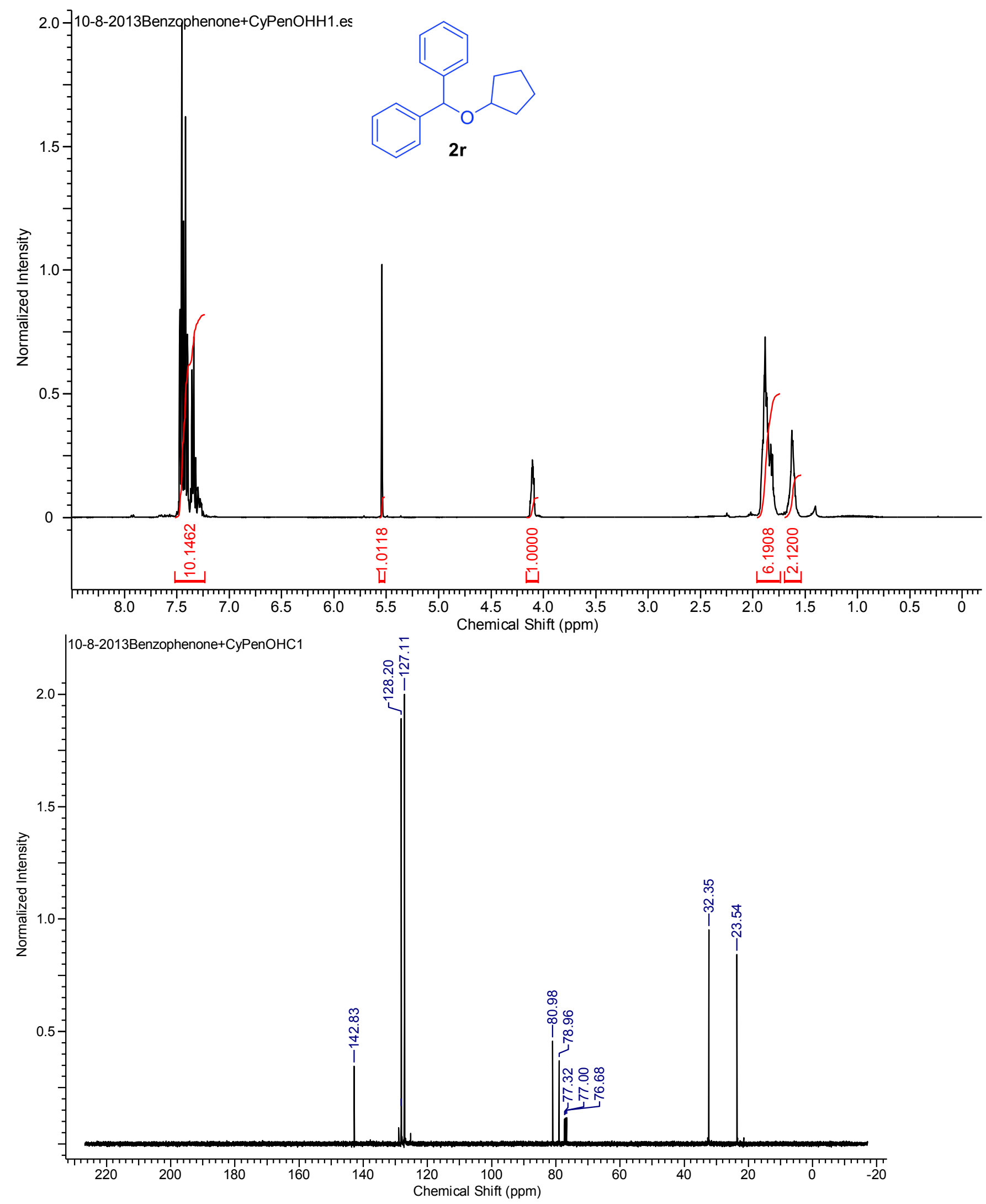

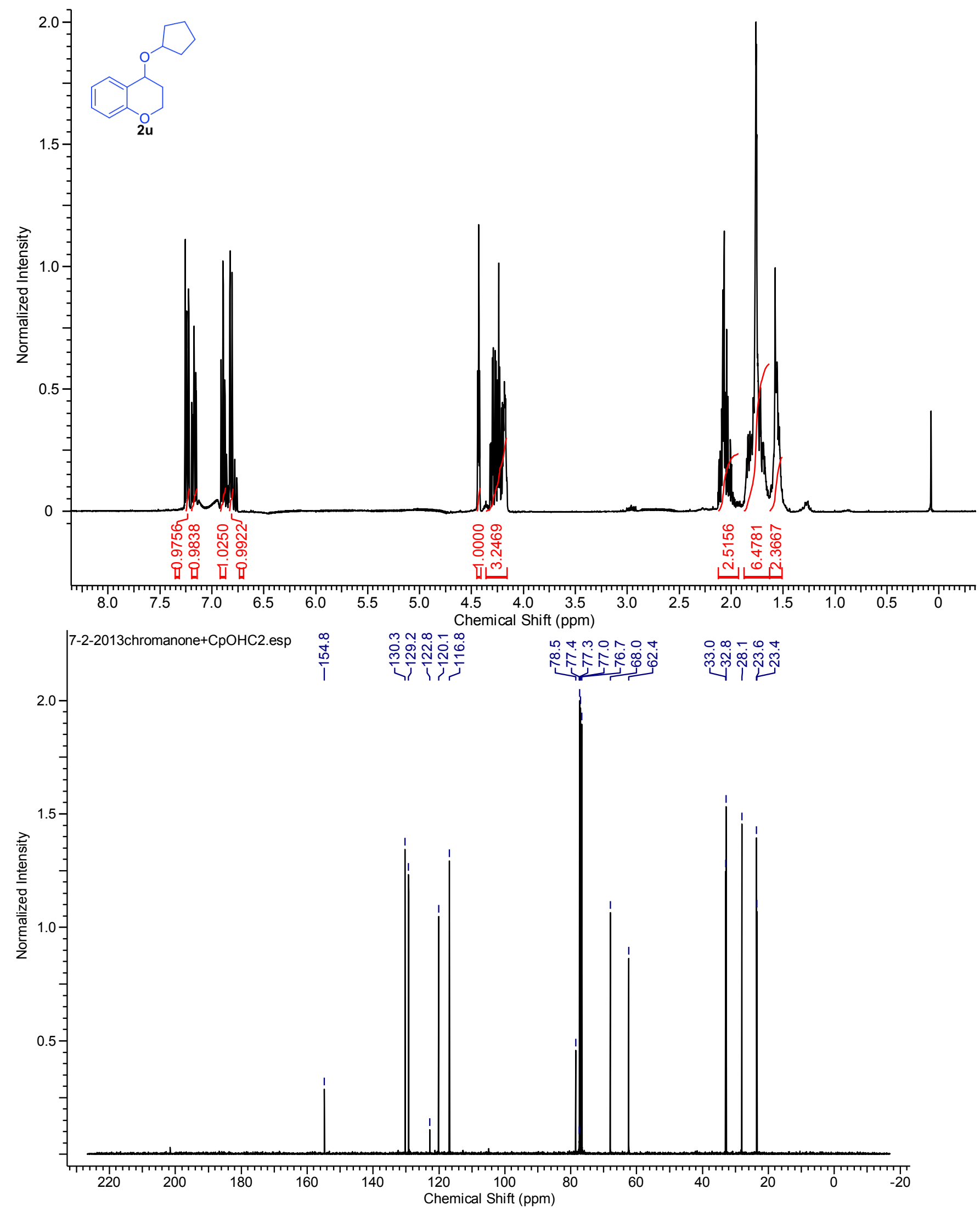

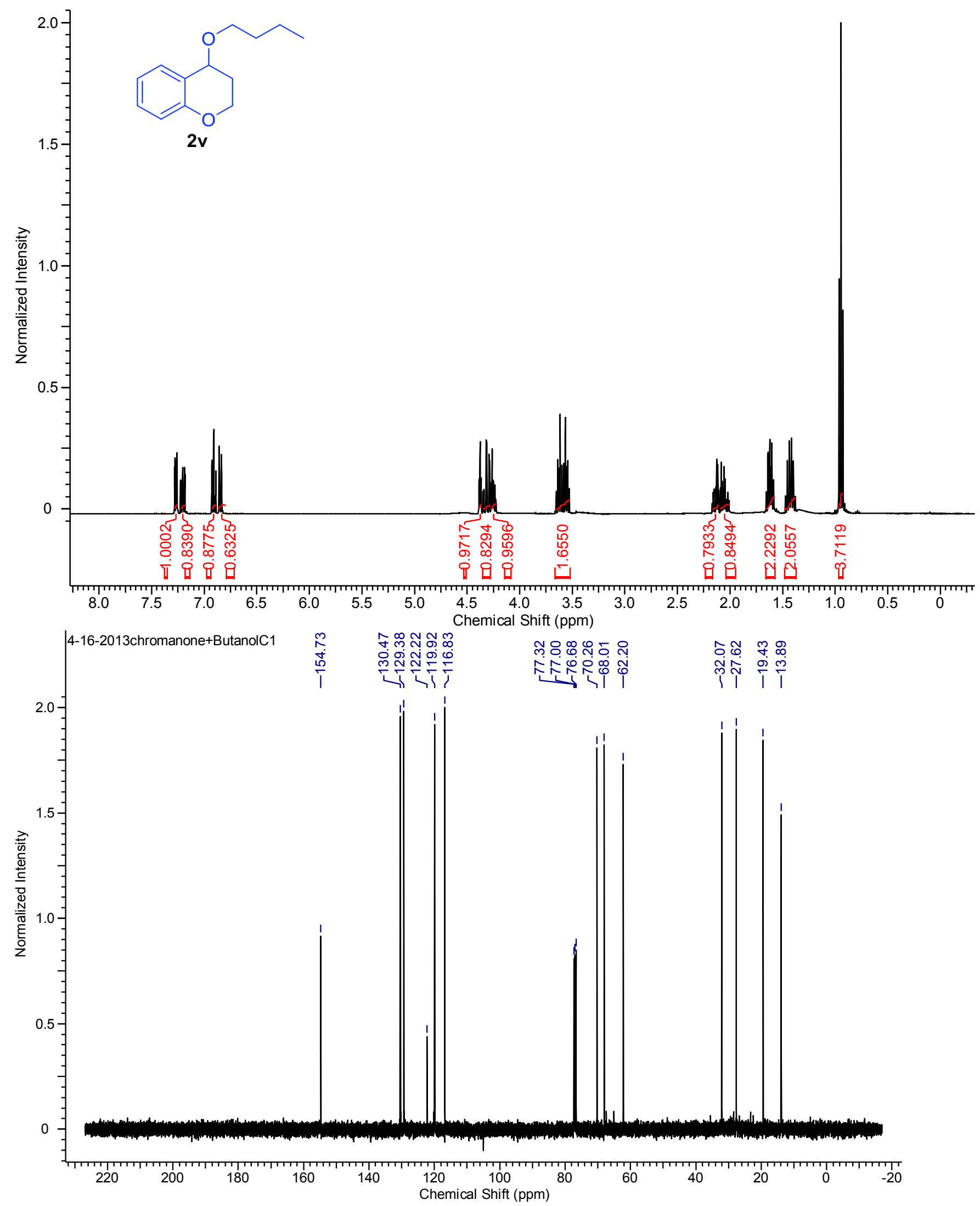

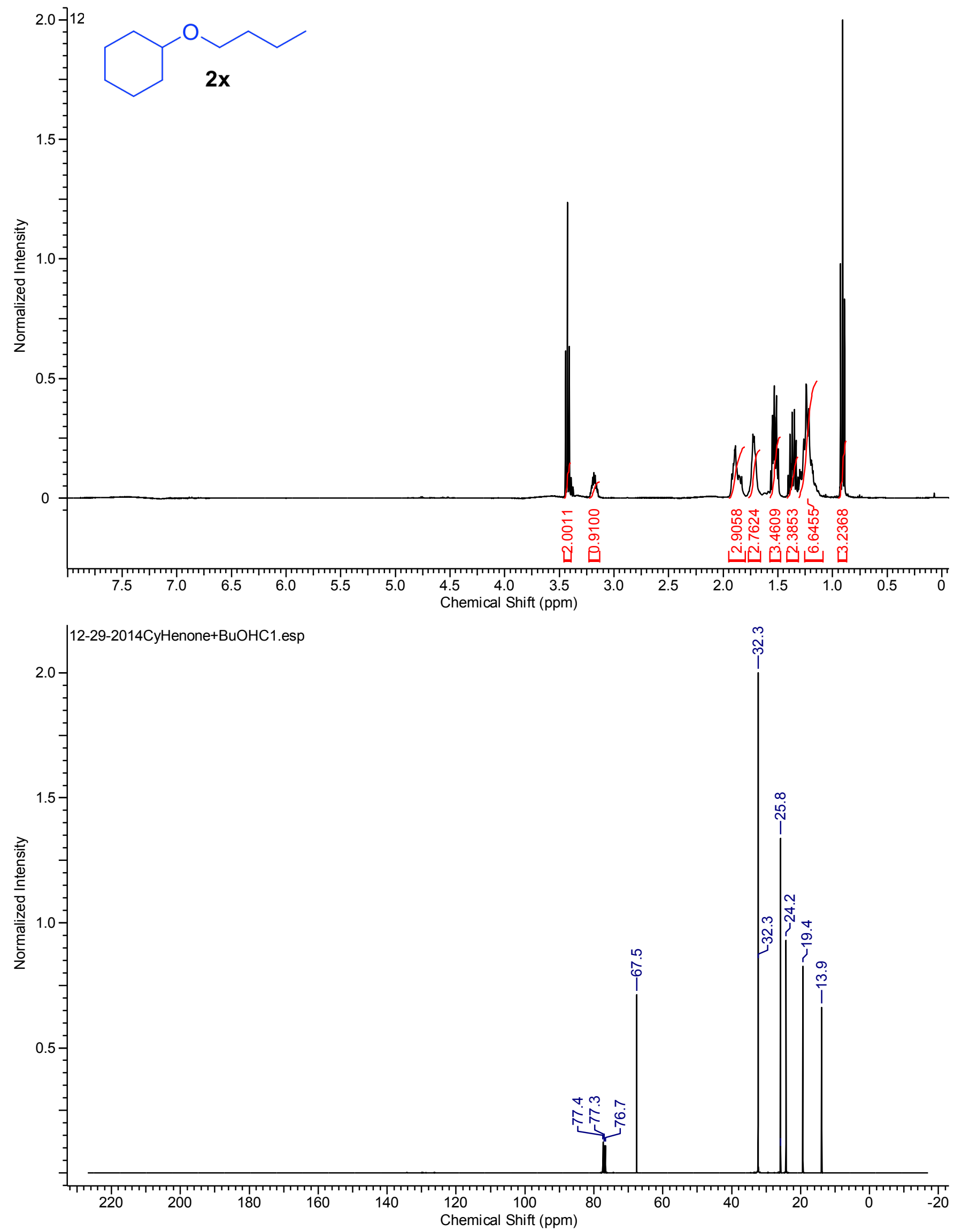


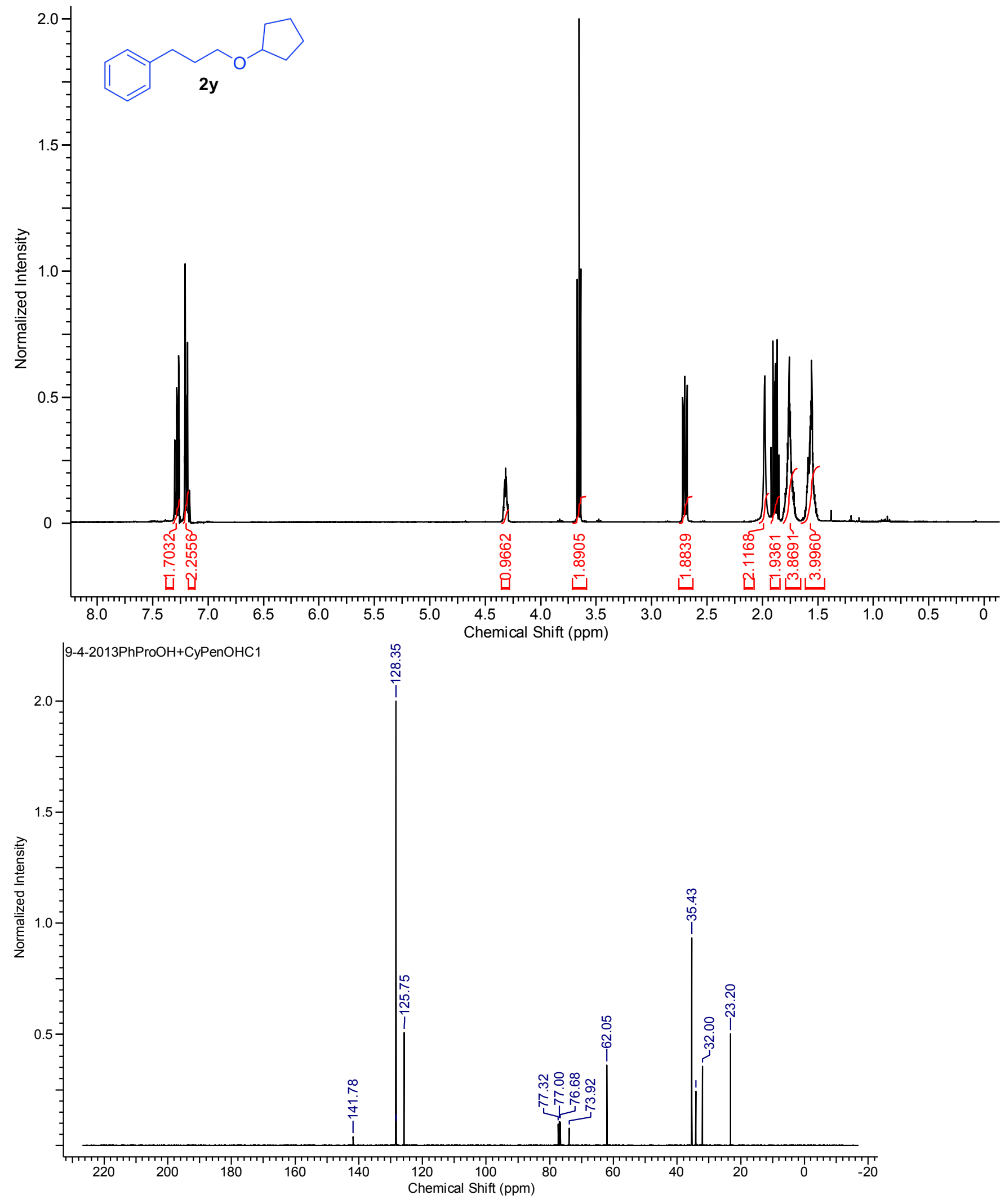



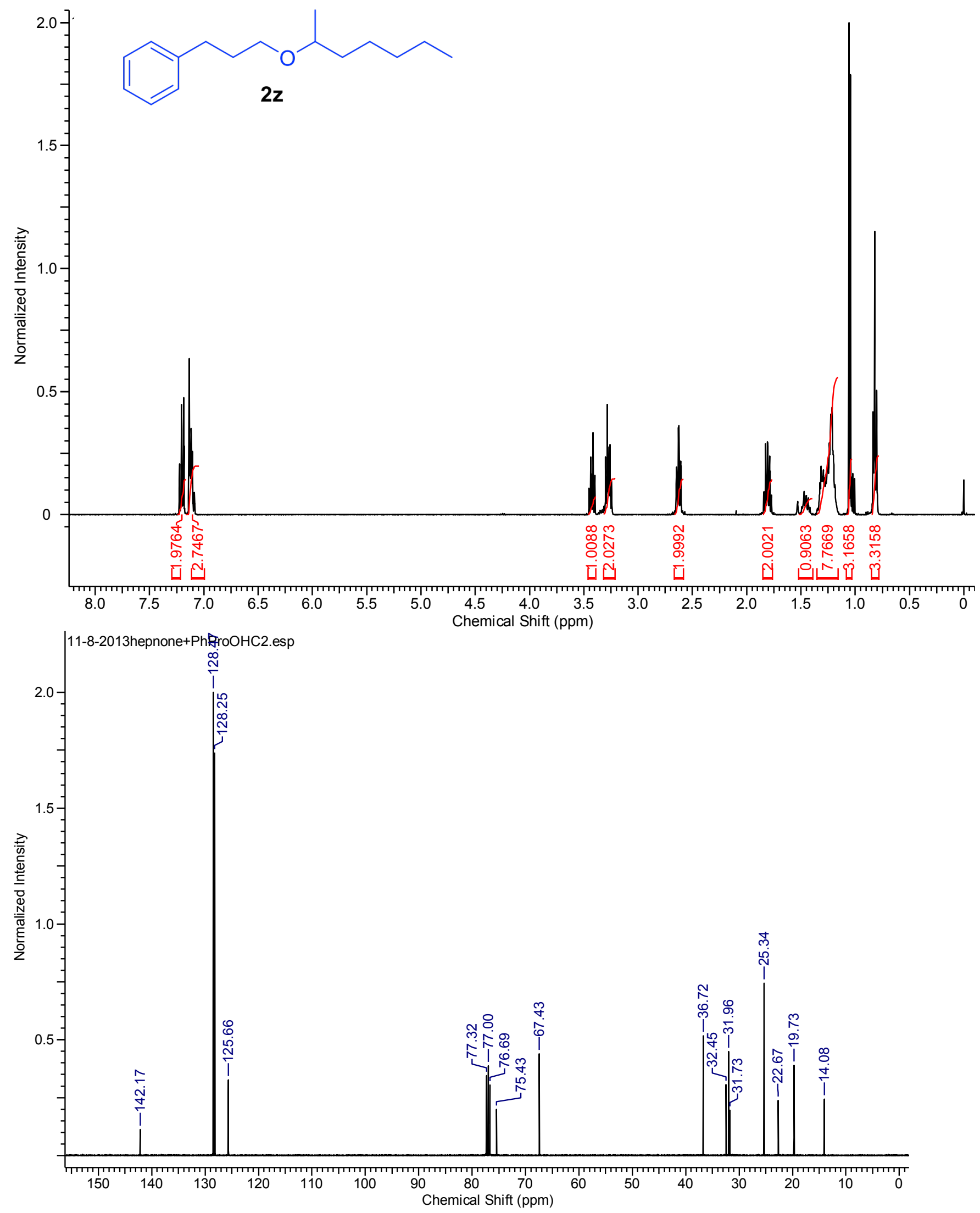


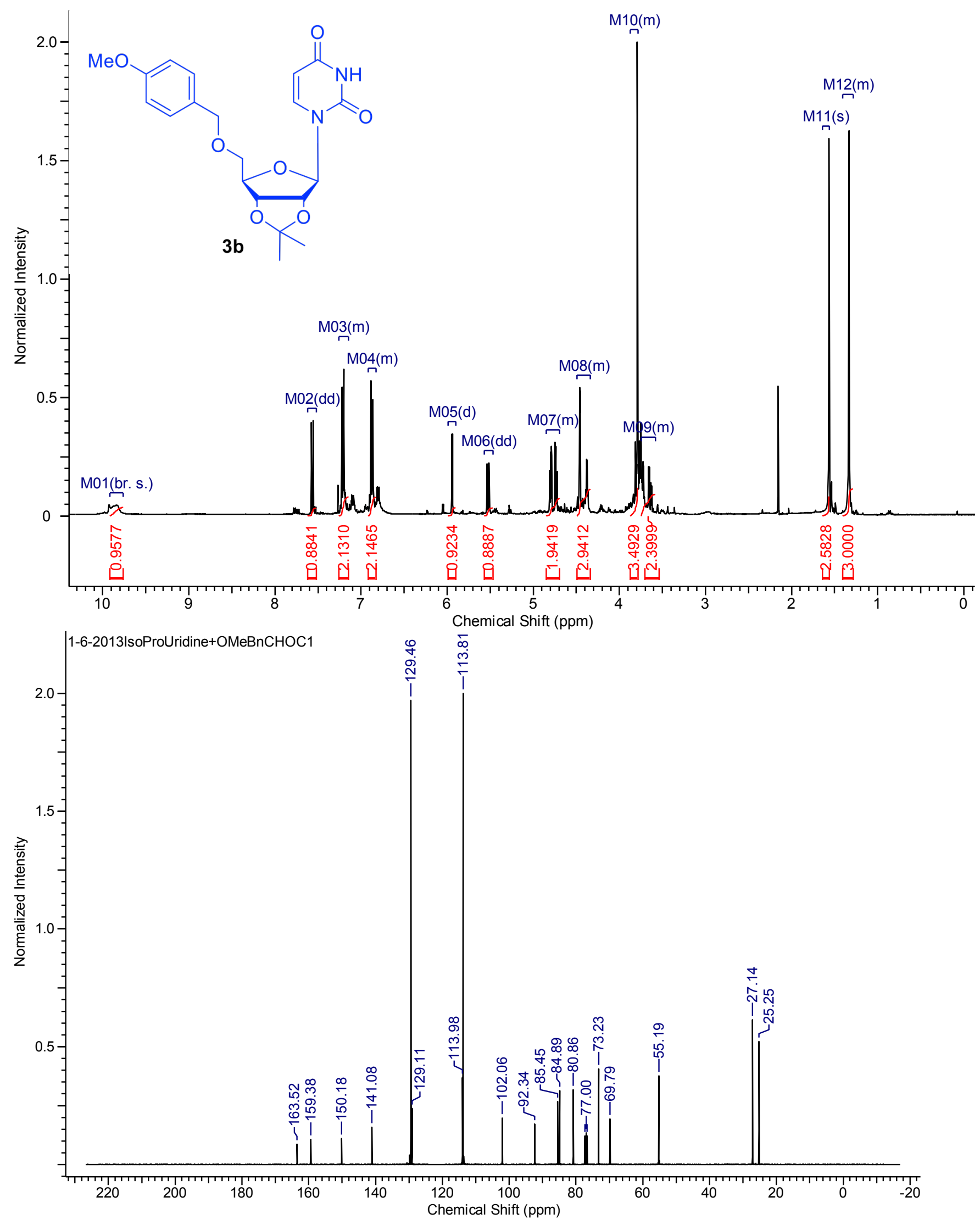



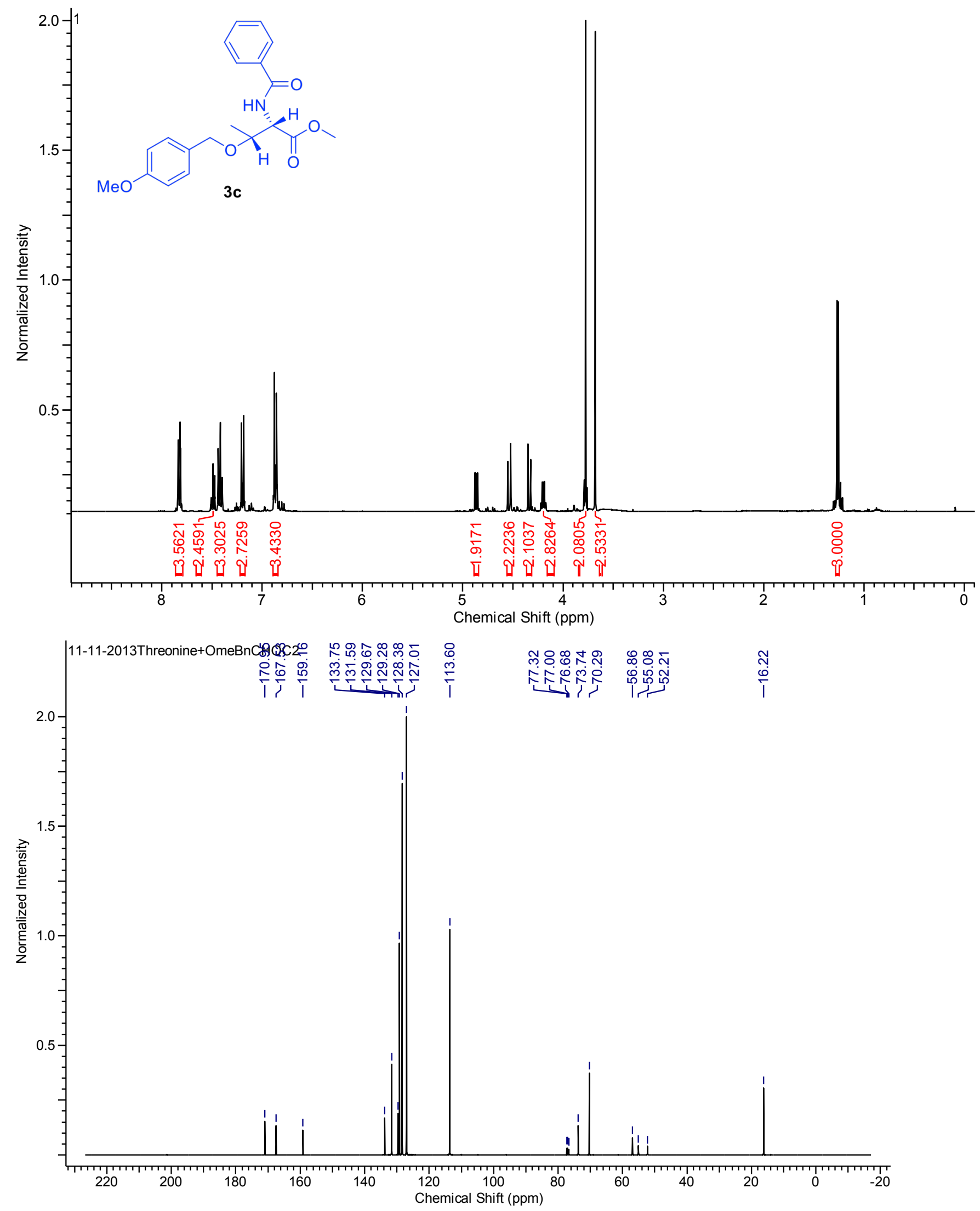

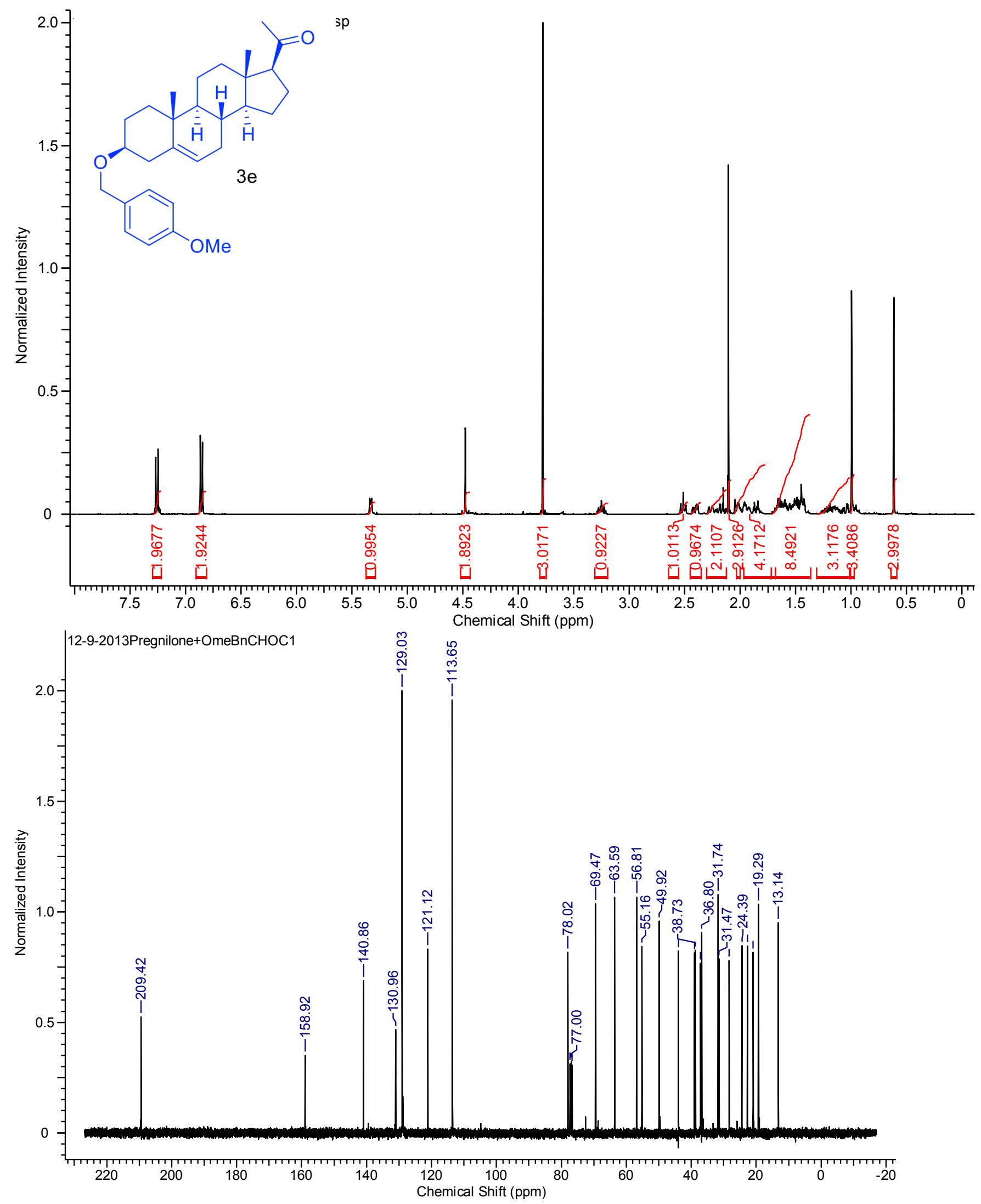

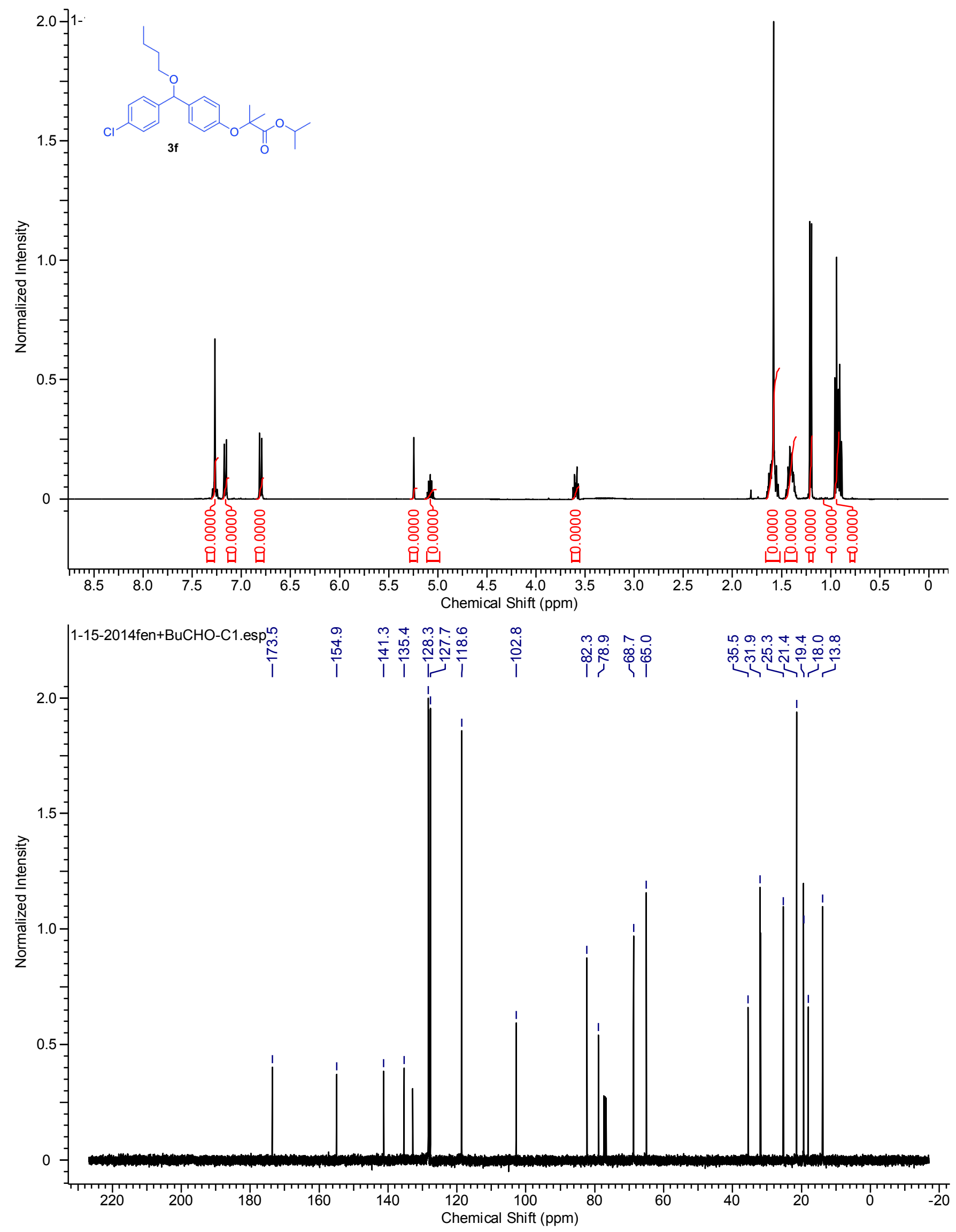

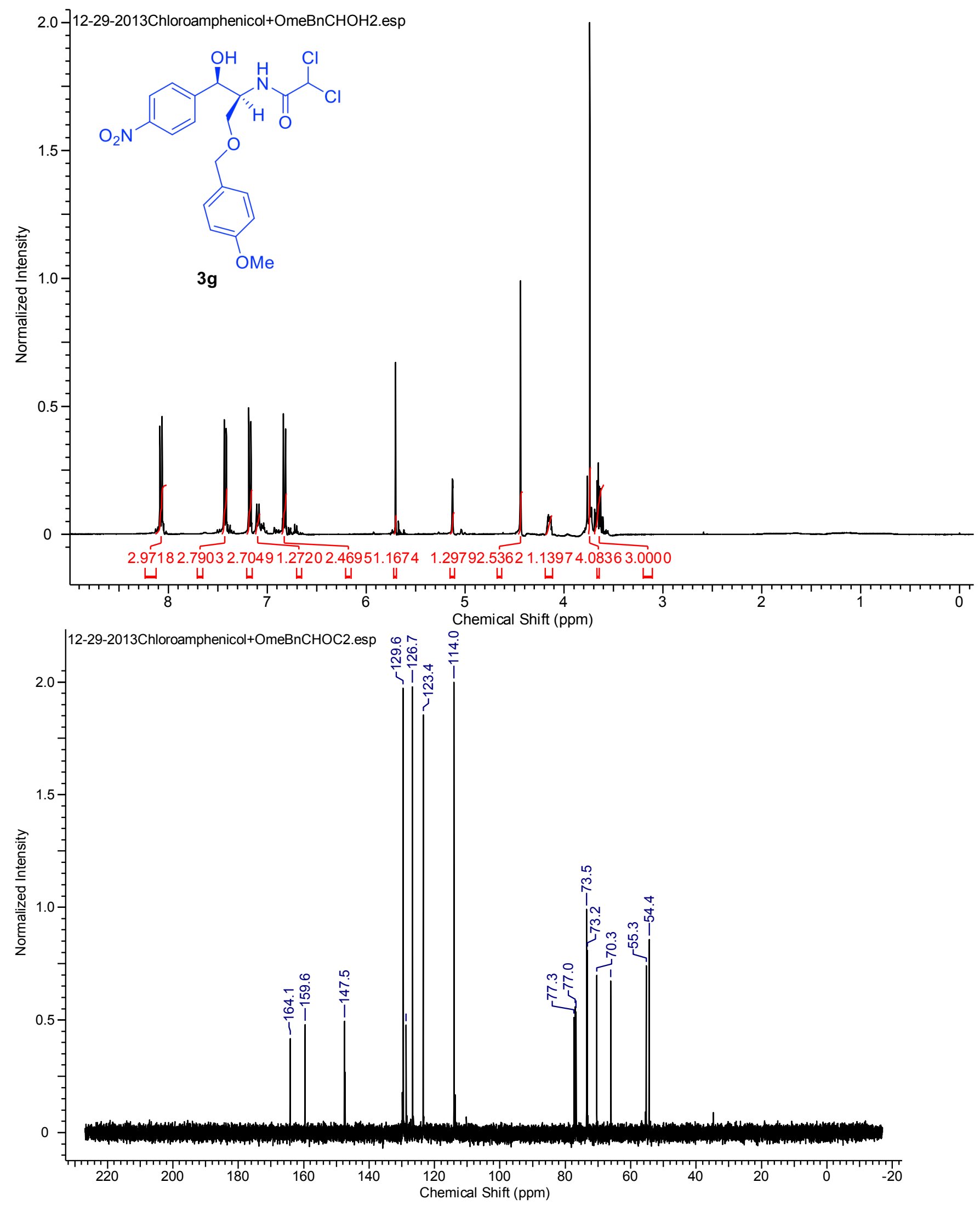

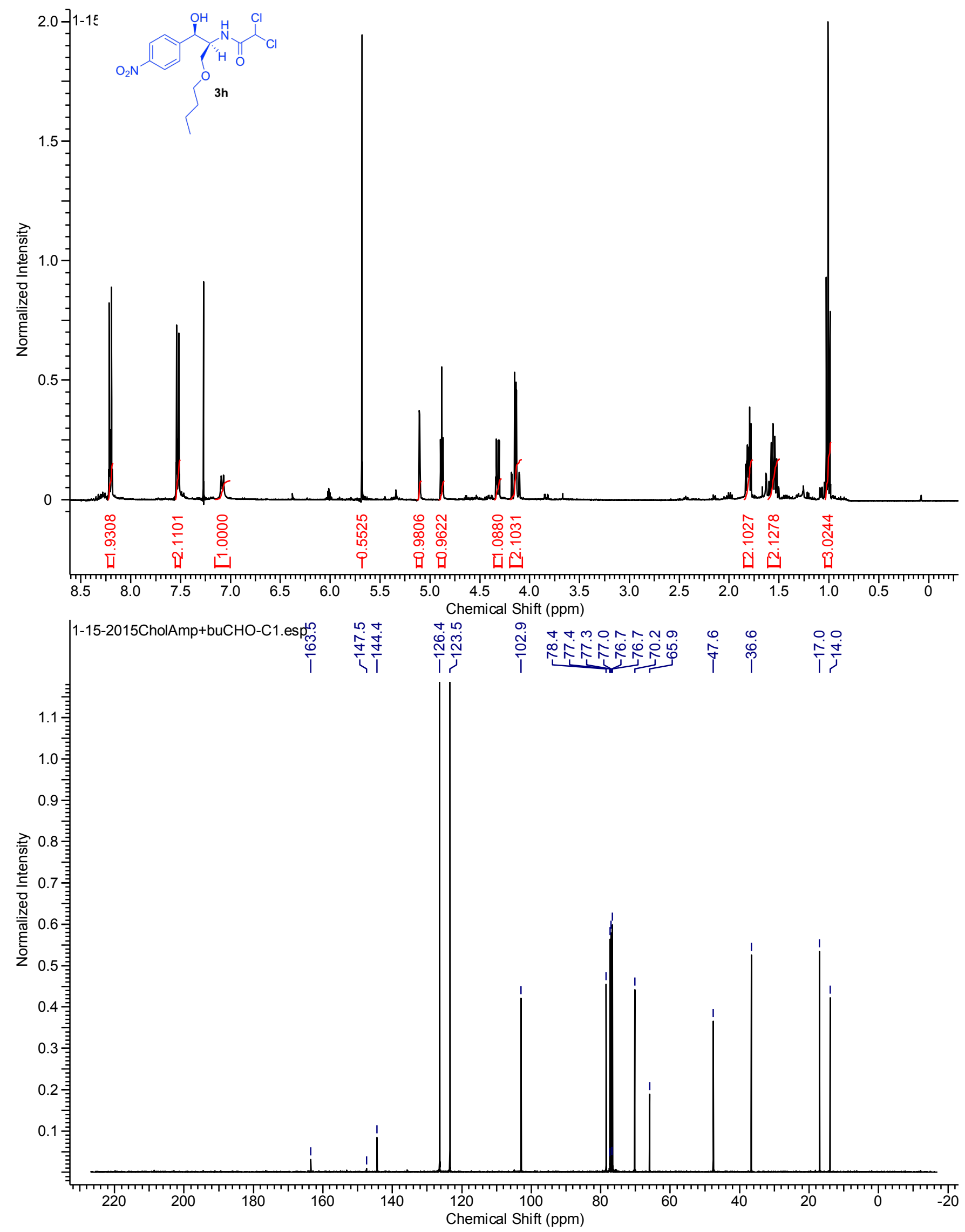

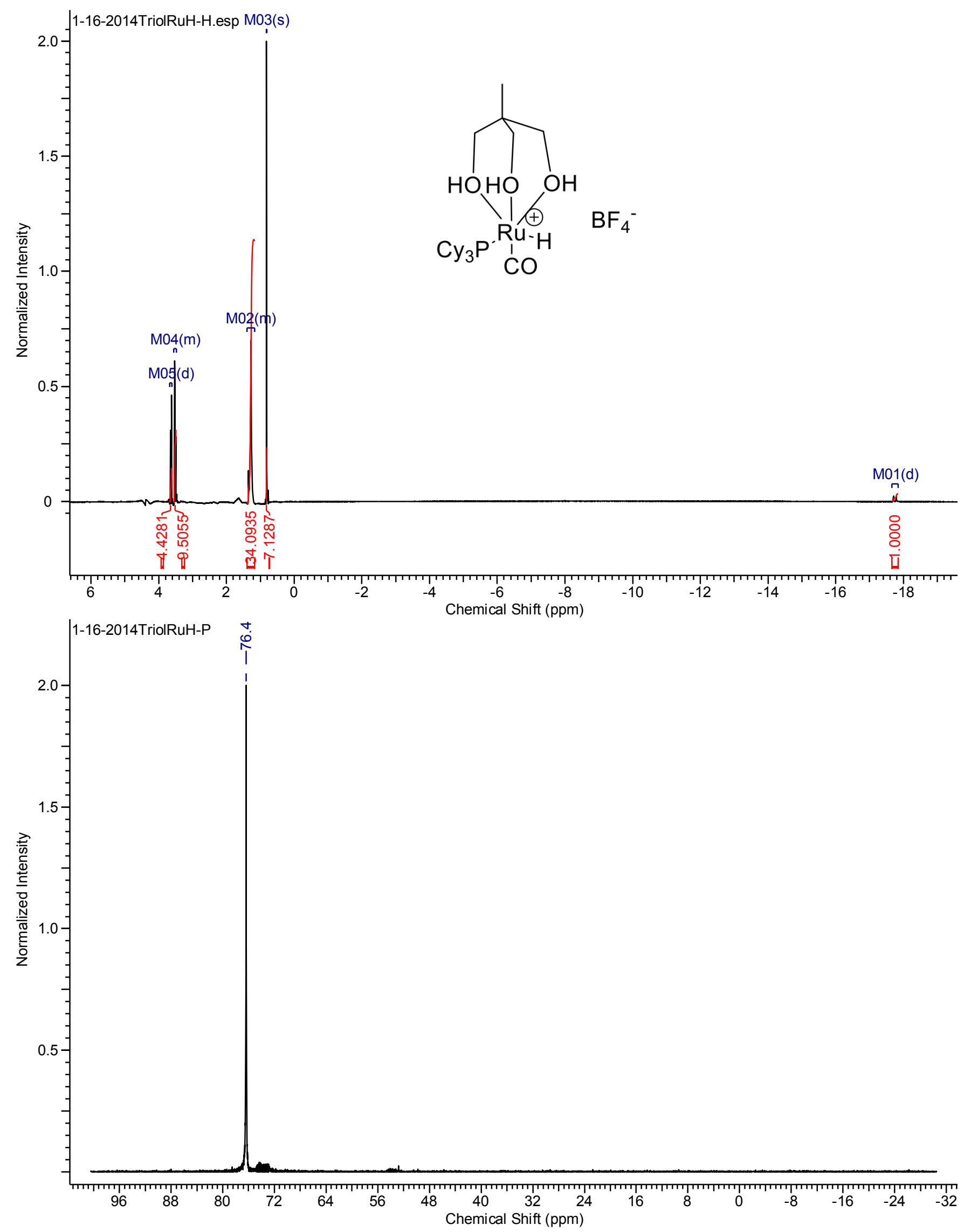


\section{X-ray Crystallograhic Data of 3e and 4c.}

Table S8. Crystal data and structure refinement for $3 \mathrm{e}$.

\begin{tabular}{|c|c|}
\hline Identification code & yi2o \\
\hline Empirical formula & $\mathrm{C}_{29} \mathrm{H}_{40} \mathrm{O}_{3}$ \\
\hline Formula weight & 436.61 \\
\hline Temperature/K & $100.00(10)$ \\
\hline Crystal system & trigonal \\
\hline Space group & $\mathrm{P} 3_{2}$ \\
\hline $\mathrm{a} / \AA$ & $13.48807(18)$ \\
\hline $\mathrm{b} / \AA$ & $13.48807(18)$ \\
\hline $\mathrm{c} / \AA$ & $11.6705(2)$ \\
\hline$\alpha /^{\circ}$ & 90.00 \\
\hline$\beta /{ }^{\circ}$ & 90.00 \\
\hline$\gamma /{ }^{\circ}$ & 120.00 \\
\hline Volume $/ \AA^{3}$ & $1838.73(5)$ \\
\hline $\mathrm{Z}$ & 3 \\
\hline$\rho_{\text {calc }} \mathrm{mg} / \mathrm{mm}^{3}$ & 1.183 \\
\hline $\mathrm{m} / \mathrm{mm}^{-1}$ & 0.578 \\
\hline $\mathrm{F}(000)$ & 714.0 \\
\hline Crystal size $/ \mathrm{mm}^{3}$ & $0.42 \times 0.12 \times 0.05$ \\
\hline Radiation & $\mathrm{CuK} \alpha(\lambda=1.54184)$ \\
\hline $2 \Theta$ range for data collection & 7.56 to $147.18^{\circ}$ \\
\hline Index ranges & $-16 \leq \mathrm{h} \leq 16,-16 \leq \mathrm{k} \leq 16,-10 \leq 1 \leq 14$ \\
\hline Reflections collected & 11497 \\
\hline Independent reflections & $4347\left[\mathrm{R}_{\mathrm{int}}=0.0231, \mathrm{R}_{\mathrm{sigma}}=0.0230\right]$ \\
\hline Data/restraints/parameters & $4347 / 274 / 587$ \\
\hline Goodness-of-fit on $\mathrm{F}^{2}$ & 1.053 \\
\hline Final $\mathrm{R}$ indexes $[\mathrm{I}>=2 \sigma(\mathrm{I})]$ & $\mathrm{R}_{1}=0.0281, \mathrm{wR}_{2}=0.0734$ \\
\hline Final $\mathrm{R}$ indexes [all data] & $\mathrm{R}_{1}=0.0282, \mathrm{wR}_{2}=0.0736$ \\
\hline \multicolumn{2}{|c|}{ Largest diff. peak/hole / e $\AA^{-3} 0.08 /-0.10$} \\
\hline Flack parameter & $-0.09(18)$ \\
\hline
\end{tabular}


Table S9. Fractional Atomic Coordinates $\left(\times 10^{4}\right)$ and Equivalent Isotropic Displacement Parameters $\left(\AA^{2} \times 10^{3}\right)$ for $3 e$. $U_{\text {eq }}$ is defined as $1 / 3$ of of the trace of the orthogonalised $U_{I J}$ tensor.

\begin{tabular}{|c|c|c|c|c|}
\hline Atom & $x$ & $y$ & $z$ & $\mathbf{U}(\mathbf{e q})$ \\
\hline $\mathrm{O} 1$ & $5425.6(13)$ & $5635.9(14)$ & $3706.1(14)$ & $35.0(4)$ \\
\hline $\mathrm{O} 2$ & $9146(2)$ & $7728(2)$ & $-6082(3)$ & $51.1(6)$ \\
\hline $\mathrm{O} 3$ & $3876.0(16)$ & $4818.0(17)$ & $8877.2(16)$ & $45.6(4)$ \\
\hline $\mathrm{C} 1$ & $6147.7(19)$ & $7093.9(19)$ & 805 ( 2 ) & $35.9(5)$ \\
\hline $\mathrm{C} 2$ & $5954(2)$ & $6983(2)$ & $2099(2)$ & $37.5(5)$ \\
\hline $\mathrm{C} 3$ & $5576.2(19)$ & $5762.8(19)$ & $2498(2)$ & $33.0(5)$ \\
\hline $\mathrm{C} 4$ & $6500.1(19)$ & $5480.1(19)$ & $2169.7(19)$ & $32.5(5)$ \\
\hline $\mathrm{C} 5$ & $6746(5)$ & $5619(4)$ & $884(4)$ & $28.6(9)$ \\
\hline C6 & $6691.3(19)$ & $4764.5(18)$ & $278(2)$ & $33.1(5)$ \\
\hline C7 & $6921(2)$ & $4809.4(18)$ & $-979(2)$ & $34.3(5)$ \\
\hline $\mathrm{C} 8$ & $7517.4(16)$ & $6031.8(17)$ & $-1456.4(19)$ & $28.1(4)$ \\
\hline C9 & $6981.9(17)$ & $6709.5(17)$ & $-943(2)$ & $29.5(4)$ \\
\hline $\mathrm{C} 10$ & $7044.4(16)$ & $6778.2(17)$ & $379.4(19)$ & $29.1(4)$ \\
\hline $\mathrm{C} 11$ & 7477 (2) & $7893.4(18)$ & $-1518.4(19)$ & $33.4(5)$ \\
\hline $\mathrm{C} 12$ & 7427 ( 2) & $7854.2(19)$ & $-2830(2)$ & $34.5(5)$ \\
\hline $\mathrm{C} 13$ & $7994.7(18)$ & $7208.5(17)$ & $-3314.2(19)$ & $29.1(4)$ \\
\hline $\mathrm{C} 14$ & $7410.8(17)$ & $6016.2(16)$ & $-2749.7(19)$ & $29.8(4)$ \\
\hline $\mathrm{C} 15$ & $7815.3(19)$ & $5336.6(19)$ & $-3460(2)$ & $35.2(5)$ \\
\hline $\mathrm{C} 16$ & 7867 ( 2) & $5772(2)$ & $-4698(2)$ & $40.1(5)$ \\
\hline $\mathrm{C} 17$ & $7747.4(19)$ & $6850.8(19)$ & $-4599(2)$ & $35.0(5)$ \\
\hline $\mathrm{C} 18$ & $8247(2)$ & $7684.0(19)$ & $806(2)$ & $37.2(5)$ \\
\hline $\mathrm{C} 19$ & $9290(3)$ & $7886(4)$ & $-3129(4)$ & $34.8(8)$ \\
\hline $\mathrm{C} 20$ & $8444(2)$ & $7778(2)$ & $-5457(2)$ & $40.1(5)$ \\
\hline $\mathrm{C} 21$ & $8244(3)$ & $8776(2)$ & $-5541(2)$ & $49.6(6)$ \\
\hline $\mathrm{C} 22$ & $4416(2)$ & $5614(3)$ & $4096(2)$ & $44.8(6)$ \\
\hline $\mathrm{C} 23$ & $4298(5)$ & $5403(6)$ & $5373(5)$ & $40.7(11)$ \\
\hline $\mathrm{C} 24$ & $4328.4(19)$ & $6206(2)$ & $6125(2)$ & $39.0(5)$ \\
\hline $\mathrm{C} 25$ & $4192(2)$ & $5994(2)$ & $7291(2)$ & $38.3(5)$ \\
\hline $\mathrm{C} 26$ & $4012(5)$ & $4964(5)$ & $7701(5)$ & $39.3(10)$ \\
\hline $\mathrm{C} 27$ & $3983(2)$ & $4136(2)$ & $6967(2)$ & $39.2(5)$ \\
\hline $\mathrm{C} 28$ & 4119 (2) & $4372(2)$ & $5799(2)$ & $40.5(5)$ \\
\hline $\mathrm{C} 29$ & $3592(2)$ & $3730(3)$ & $9346(2)$ & $47.8(6)$ \\
\hline O1A & 7865 ( 3 ) & $6902(3)$ & $-1698(3)$ & $38.3(8)$ \\
\hline $\mathrm{O} 2 \mathrm{~A}$ & $4063(9)$ & 5155 (9) & 8007 ( 8 ) & $66(3)$ \\
\hline
\end{tabular}




\begin{tabular}{|c|c|c|c|c|}
\hline $\mathrm{O} 3 \mathrm{~A}$ & $9386(3)$ & $7584(4)$ & $-6864(3)$ & $50.8(10)$ \\
\hline $\mathrm{C} 1 \mathrm{~A}$ & 7125 ( 5) & 7595 ( 4 ) & $1202(4)$ & $40.2(11)$ \\
\hline $\mathrm{C} 2 \mathrm{~A}$ & $7316(5)$ & $7694(4)$ & $-88(5)$ & $42.6(12)$ \\
\hline $\mathrm{C} 3 \mathrm{~A}$ & $7683(5)$ & $6855(4)$ & $-492(4)$ & $38.4(11)$ \\
\hline $\mathrm{C} 4 \mathrm{~A}$ & $6774(5)$ & $5636(4)$ & $-173(5)$ & $42.2(12)$ \\
\hline C5A & $6525(11)$ & $5517(9)$ & $1128(10)$ & $32(2)$ \\
\hline C6A & $6584(4)$ & $4720(4)$ & $1693(5)$ & $39.2(11)$ \\
\hline C7A & $6353(5)$ & $4517(4)$ & 2947 ( 5 ) & $41.0(12)$ \\
\hline $\mathrm{C} 8 \mathrm{~A}$ & $5748(4)$ & $5128(4)$ & $3455(4)$ & $34.6(10)$ \\
\hline C9A & $6308(4)$ & $6353(4)$ & $2962(4)$ & $35.4(10)$ \\
\hline $\mathrm{C} 10 \mathrm{~A}$ & $6226(4)$ & $6375(4)$ & $1618(4)$ & $35.9(11)$ \\
\hline $\mathrm{C} 11 \mathrm{~A}$ & $5846(5)$ & $7066(5)$ & $3533(4)$ & $39.9(11)$ \\
\hline $\mathrm{C} 12 \mathrm{~A}$ & $5903(4)$ & $7058(4)$ & $4854(4)$ & $34.5(10)$ \\
\hline C13A & $5316(4)$ & $5836(4)$ & $5324(4)$ & $36.8(10)$ \\
\hline C14A & $5871(4)$ & $5208(4)$ & $4753(4)$ & $34.5(10)$ \\
\hline $\mathrm{C} 15 \mathrm{~A}$ & $5442(5)$ & $4112(4)$ & $5459(4)$ & $40.3(11)$ \\
\hline $\mathrm{C} 16 \mathrm{~A}$ & $5394(6)$ & $4490(5)$ & $6687(5)$ & $47.4(13)$ \\
\hline C17A & $5550(4)$ & $5704(4)$ & $6608(4)$ & $36.9(10)$ \\
\hline C18A & $5022(4)$ & $6077(5)$ & $1214(5)$ & $40.2(11)$ \\
\hline C19A & $4042(8)$ & $5249(11)$ & $5119(10)$ & $34(2)$ \\
\hline $\mathrm{C} 20 \mathrm{~A}$ & $4822(6)$ & $5931(5)$ & 7449 ( 5 ) & $46.9(13)$ \\
\hline $\mathrm{C} 21 \mathrm{~A}$ & $5096(6)$ & 7159 (5) & $7564(5)$ & $55.6(15)$ \\
\hline $\mathrm{C} 22 \mathrm{~A}$ & $8845(5)$ & $7918(5)$ & $-2072(5)$ & $52.2(14)$ \\
\hline $\mathrm{C} 23 \mathrm{~A}$ & $8955(7)$ & $7802(9)$ & $-3339(8)$ & $43(2)$ \\
\hline $\mathrm{C} 24 \mathrm{~A}$ & $9004(4)$ & $8614(5)$ & $-4119(5)$ & $40.4(11)$ \\
\hline $\mathrm{C} 25 \mathrm{~A}$ & $9139(5)$ & $8502(6)$ & $-5274(5)$ & $46.6(13)$ \\
\hline $\mathrm{C} 26 \mathrm{~A}$ & 9309 ( 7 ) & $7663(8)$ & $-5650(5)$ & $47(2)$ \\
\hline $\mathrm{C} 27 \mathrm{~A}$ & $9281(5)$ & $6830(5)$ & $-4930(5)$ & $46.1(12)$ \\
\hline $\mathrm{C} 28 \mathrm{~A}$ & $9137(5)$ & $6944(5)$ & $-3779(4)$ & $42.5(11)$ \\
\hline C29A & $9681(5)$ & $6786(6)$ & $-7293(5)$ & $50.9(14)$ \\
\hline
\end{tabular}

Table S10. Anisotropic Displacement Parameters $\left(\AA^{2} \times 10^{3}\right)$ for 3e. The Anisotropic displacement factor exponent takes the form: $-2 \pi^{2}\left[h^{2} a *^{2} U_{11}+2 h k a * b * U_{12}+\ldots\right]$.

\begin{tabular}{|c|c|c|c|c|c|c|}
\hline Atom & $\mathrm{U}_{11}$ & $\mathbf{U}_{22}$ & $\mathbf{U}_{33}$ & $\mathbf{U}_{23}$ & $\mathbf{U}_{13}$ & $\mathbf{U}_{12}$ \\
\hline $\mathrm{O} 1$ & $30.5(7)$ & $38.8(9)$ & $40.0(9)$ & $3.9(7)$ & $3.6(7)$ & $20.6(7)$ \\
\hline $\mathrm{O} 2$ & $45.0(14)$ & $41.8(11)$ & $61.0(19)$ & $6.8(12)$ & $15.6(14)$ & $17.5(10)$ \\
\hline
\end{tabular}




\begin{tabular}{|c|c|c|c|c|c|c|}
\hline $\mathrm{O} 3$ & $38.3(9)$ & $45(1)$ & $42.8(11)$ & $-1.0(8)$ & $8.5(8)$ & $12.8(8)$ \\
\hline $\mathrm{C} 1$ & $36.2(12)$ & $34.3(11)$ & $43.5(13)$ & $3.8(10)$ & $1.9(9)$ & $22.4(10)$ \\
\hline $\mathrm{C} 2$ & $43.5(12)$ & $35.5(11)$ & $41.3(13)$ & $4.2(10)$ & $5.3(10)$ & $25.5(10)$ \\
\hline $\mathrm{C} 3$ & $31.0(11)$ & $32.8(11)$ & $37.9(12)$ & $3.2(9)$ & $1.8(10)$ & $18(1)$ \\
\hline $\mathrm{C} 4$ & $30.5(10)$ & $28(1)$ & $38.6(14)$ & $6.8(9)$ & $5.6(9)$ & $14.3(8)$ \\
\hline $\mathrm{C} 5$ & $24(2)$ & $29.0(16)$ & $33(2)$ & $6.6(12)$ & $6.7(14)$ & $14.0(16)$ \\
\hline C6 & $31.6(10)$ & $22.1(9)$ & $46.1(13)$ & $7.0(8)$ & $6.7(9)$ & $13.9(8)$ \\
\hline $\mathrm{C} 7$ & $33.4(11)$ & $22.8(10)$ & $46.1(13)$ & $2.7(8)$ & $4.4(9)$ & $13.7(8)$ \\
\hline $\mathrm{C} 8$ & $23.2(9)$ & $22.2(10)$ & $38.5(12)$ & $3.1(8)$ & $1.9(8)$ & $11.0(8)$ \\
\hline $\mathrm{C} 9$ & $23.9(9)$ & $22.9(9)$ & $41.1(12)$ & $1.7(8)$ & $-0.2(9)$ & $11.1(7)$ \\
\hline $\mathrm{C} 10$ & $26.7(9)$ & $21.2(9)$ & $37.5(11)$ & $2.5(8)$ & $2.0(8)$ & $10.6(8)$ \\
\hline $\mathrm{C} 11$ & $39.4(11)$ & $23.7(9)$ & $37.8(12)$ & $2.4(9)$ & $2.9(9)$ & $16.3(9)$ \\
\hline $\mathrm{C} 12$ & $33.9(11)$ & $25.6(10)$ & $43.9(13)$ & $3.9(9)$ & $2.6(9)$ & $14.9(8)$ \\
\hline $\mathrm{C} 13$ & $25.6(11)$ & $21.3(9)$ & $36.9(12)$ & $2.7(8)$ & $1.7(8)$ & $9.0(9)$ \\
\hline $\mathrm{C} 14$ & $21.4(9)$ & $22.8(9)$ & $43.1(12)$ & $2.0(9)$ & $1.7(8)$ & $9.5(8)$ \\
\hline $\mathrm{C} 15$ & $32.2(10)$ & $26.1(10)$ & $45.1(13)$ & $1.8(9)$ & $5.1(9)$ & $13.0(9)$ \\
\hline $\mathrm{C} 16$ & $44.6(13)$ & $31.6(11)$ & $43.8(13)$ & $-2.2(10)$ & $2.3(10)$ & $18.9(10)$ \\
\hline $\mathrm{C} 17$ & $33.2(10)$ & $28.9(10)$ & $41.8(13)$ & $-0.7(9)$ & $2.6(9)$ & $14.8(9)$ \\
\hline $\mathrm{C} 18$ & $34.3(11)$ & $29.3(10)$ & $43.1(12)$ & $1.1(9)$ & $-2.0(9)$ & $12.2(9)$ \\
\hline $\mathrm{C} 19$ & $17.2(17)$ & $27.1(13)$ & $46.3(19)$ & $3.8(13)$ & $2.8(13)$ & $0.7(14)$ \\
\hline $\mathrm{C} 20$ & $40.6(14)$ & $33.4(12)$ & $42.2(13)$ & $2.4(10)$ & $3.1(11)$ & $15.5(11)$ \\
\hline $\mathrm{C} 21$ & 70.9 ( 19$)$ & $41.0(13)$ & $41.5(13)$ & $5.5(11)$ & $9.9(13)$ & $31.3(13)$ \\
\hline $\mathrm{C} 22$ & $38.9(12)$ & $61.1(16)$ & $44.5(14)$ & $3.0(12)$ & $4.7(11)$ & $32.5(12)$ \\
\hline $\mathrm{C} 23$ & $31(2)$ & $51(3)$ & $42(2)$ & $-1.9(17)$ & $0.4(16)$ & $22(2)$ \\
\hline $\mathrm{C} 24$ & $27.9(10)$ & $33.6(11)$ & $52.5(14)$ & $-2.1(10)$ & $1.3(9)$ & $13.1(9)$ \\
\hline $\mathrm{C} 25$ & $29.2(11)$ & $33.6(11)$ & $46.0(14)$ & $-6.8(10)$ & $2.2(10)$ & $11.1(9)$ \\
\hline $\mathrm{C} 26$ & $27.1(15)$ & $43.0(16)$ & $40(2)$ & $-1.0(14)$ & $7.6(14)$ & $11.7(12)$ \\
\hline $\mathrm{C} 27$ & $34.7(11)$ & $37.0(12)$ & $46.2(13)$ & $1.6(10)$ & $3.6(10)$ & $18(1)$ \\
\hline $\mathrm{C} 28$ & $40.6(12)$ & $42.9(12)$ & $45.1(13)$ & $-6.4(10)$ & $0.5(10)$ & $26.1(11)$ \\
\hline $\mathrm{C} 29$ & $39.2(13)$ & $55.3(17)$ & $43.8(15)$ & $9.2(12)$ & $2.4(11)$ & $19.8(13)$ \\
\hline O1A & $37.3(17)$ & $33.2(18)$ & $37.8(19)$ & $-0.1(14)$ & $7.0(14)$ & $12.6(15)$ \\
\hline $\mathrm{O} 2 \mathrm{~A}$ & $65(5)$ & $78(6)$ & $68(6)$ & $31(5)$ & $40(4)$ & $46(4)$ \\
\hline $\mathrm{O} 3 \mathrm{~A}$ & $38.1(19)$ & $78(3)$ & $31(2)$ & $5.6(19)$ & $6.8(16)$ & $25(2)$ \\
\hline $\mathrm{C} 1 \mathrm{~A}$ & $48(3)$ & $27(2)$ & $46(3)$ & $0.6(18)$ & $8(2)$ & $19(2)$ \\
\hline $\mathrm{C} 2 \mathrm{~A}$ & $51(3)$ & $33(2)$ & $42(3)$ & $3(2)$ & $8(2)$ & $19(2)$ \\
\hline $\mathrm{C} 3 \mathrm{~A}$ & $45(3)$ & $28(2)$ & $36(3)$ & $3.3(19)$ & $2(2)$ & $13.9(19)$ \\
\hline $\mathrm{C} 4 \mathrm{~A}$ & $43(3)$ & $32(2)$ & $53(3)$ & $-8(2)$ & $8(2)$ & $20(2)$ \\
\hline
\end{tabular}




\begin{tabular}{|c|c|c|c|c|c|c|}
\hline $\mathrm{C} 5 \mathrm{~A}$ & $20(4)$ & $24(3)$ & $51(5)$ & $3(3)$ & $14(3)$ & $10(3)$ \\
\hline C6A & $37(2)$ & $35(2)$ & 49 (3) & $-7(2)$ & $7(2)$ & $20.6(19)$ \\
\hline C7A & $42(3)$ & $39(2)$ & $45(3)$ & $6(2)$ & $9(2)$ & $22(2)$ \\
\hline $\mathrm{C} 8 \mathrm{~A}$ & $27(2)$ & $32(2)$ & $45(3)$ & $0.4(19)$ & $1.6(19)$ & $14.8(18)$ \\
\hline C9A & $29(2)$ & $39(2)$ & $39(2)$ & $-1(2)$ & $4(2)$ & $17(2)$ \\
\hline $\mathrm{C} 10 \mathrm{~A}$ & $35(2)$ & $29(2)$ & $42(3)$ & $0.6(19)$ & $6(2)$ & $15.0(19)$ \\
\hline C11A & $49(3)$ & $39(2)$ & $39(3)$ & $-1(2)$ & $2(2)$ & $27(2)$ \\
\hline $\mathrm{C} 12 \mathrm{~A}$ & $40(2)$ & $34(2)$ & $32(2)$ & $-3.7(18)$ & $2.9(19)$ & $20.7(19)$ \\
\hline $\mathrm{C} 13 \mathrm{~A}$ & $30(2)$ & $34(2)$ & $45(3)$ & $-1(2)$ & $-1(2)$ & $15(2)$ \\
\hline $\mathrm{C} 14 \mathrm{~A}$ & $24(2)$ & $33(2)$ & $47(3)$ & $2.4(19)$ & $3.3(18)$ & $14.7(18)$ \\
\hline $\mathrm{C} 15 \mathrm{~A}$ & $38(2)$ & $39(2)$ & $45(3)$ & $5(2)$ & $4(2)$ & $20(2)$ \\
\hline $\mathrm{C} 16 \mathrm{~A}$ & $57(3)$ & $49(3)$ & $46(3)$ & $6(2)$ & $9(2)$ & $34(3)$ \\
\hline $\mathrm{C} 17 \mathrm{~A}$ & $35(2)$ & $46(3)$ & $39(3)$ & $1(2)$ & $4.7(19)$ & $27(2)$ \\
\hline $\mathrm{C} 18 \mathrm{~A}$ & $33(2)$ & $42(3)$ & $48(3)$ & $1(2)$ & $3(2)$ & $20(2)$ \\
\hline C19A & $25(4)$ & $35(3)$ & $48(6)$ & $-5(4)$ & $3(3)$ & $18(3)$ \\
\hline $\mathrm{C} 20 \mathrm{~A}$ & $60(4)$ & $45(3)$ & $47(3)$ & $4(2)$ & $9(3)$ & $34(3)$ \\
\hline $\mathrm{C} 21 \mathrm{~A}$ & $81(4)$ & $64(3)$ & $43(3)$ & $0(3)$ & $11(3)$ & $52(4)$ \\
\hline $\mathrm{C} 22 \mathrm{~A}$ & $55(3)$ & $33(3)$ & $46(3)$ & $-5(2)$ & $2(2)$ & $5(2)$ \\
\hline $\mathrm{C} 23 \mathrm{~A}$ & $25(5)$ & $41(3)$ & $46(4)$ & $-8(3)$ & $-4(3)$ & $3(4)$ \\
\hline $\mathrm{C} 24 \mathrm{~A}$ & $25(2)$ & $41(3)$ & $48(3)$ & $-2(2)$ & $0.8(19)$ & $11(2)$ \\
\hline $\mathrm{C} 25 \mathrm{~A}$ & $35(3)$ & $64(4)$ & $47(3)$ & $7(3)$ & $1(2)$ & $30(3)$ \\
\hline $\mathrm{C} 26 \mathrm{~A}$ & $32(3)$ & $91(5)$ & $22(3)$ & $1(3)$ & $-3(2)$ & $35(3)$ \\
\hline $\mathrm{C} 27 \mathrm{~A}$ & $35(2)$ & $46(3)$ & $52(3)$ & $2(2)$ & $0(2)$ & $17(2)$ \\
\hline $\mathrm{C} 28 \mathrm{~A}$ & $43(3)$ & $33(2)$ & $41(3)$ & $5(2)$ & $3(2)$ & $11(2)$ \\
\hline C29A & $40(3)$ & $56(4)$ & $38(3)$ & $-5(2)$ & $0(2)$ & $10(3)$ \\
\hline
\end{tabular}

Table S11. Bond Lengths for $3 \mathrm{e}$.

\begin{tabular}{|c|c|c|c|c|}
\hline \multicolumn{2}{|c|}{ Atom Atom } & \multirow{2}{*}{$\begin{array}{l}\text { Length/Å } \\
1.423(3)\end{array}$} & \multirow{2}{*}{$\begin{array}{l}\text { Atom Atom } \\
\text { O1A C3A }\end{array}$} & \multirow{2}{*}{$\begin{array}{l}\text { Length } / \AA \AA \\
1.425(5)\end{array}$} \\
\hline $\mathrm{O} 1$ & $\mathrm{C} 3$ & & & \\
\hline $\mathrm{O} 1$ & $\mathrm{C} 22$ & $1.422(3)$ & $\mathrm{O} 1 \mathrm{~A} \quad \mathrm{C} 22 \mathrm{~A}$ & $1.415(6)$ \\
\hline $\mathrm{O} 2$ & $\mathrm{C} 20$ & $1.224(4)$ & $\mathrm{O} 2 \mathrm{~A} \mathrm{C} 20 \mathrm{~A}$ & $1.223(10)$ \\
\hline $\mathrm{O} 3$ & $\mathrm{C} 26$ & $1.386(6)$ & O3A C26A & $1.428(6)$ \\
\hline $\mathrm{O} 3$ & $\mathrm{C} 29$ & $1.428(4)$ & O3A C29A & $1.413(8)$ \\
\hline $\mathrm{C} 1$ & $\mathrm{C} 2$ & $1.527(3)$ & $\mathrm{C} 1 \mathrm{~A} \quad \mathrm{C} 2 \mathrm{~A}$ & $1.522(6)$ \\
\hline $\mathrm{C} 1$ & $\mathrm{C} 10$ & $1.551(3)$ & $\mathrm{C} 1 \mathrm{~A} \quad \mathrm{C} 10 \mathrm{~A}$ & $1.555(6)$ \\
\hline $\mathrm{C} 2$ & $\mathrm{C} 3$ & $1.532(3)$ & $\mathrm{C} 2 \mathrm{~A} \quad \mathrm{C} 3 \mathrm{~A}$ & $1.519(7)$ \\
\hline
\end{tabular}




\begin{tabular}{|c|c|c|c|c|}
\hline $\mathrm{C} 3$ & $\mathrm{C} 4$ & $1.523(3)$ & $\mathrm{C} 3 \mathrm{~A} \quad \mathrm{C} 4 \mathrm{~A}$ & $1.525(6)$ \\
\hline $\mathrm{C} 4$ & $\mathrm{C} 5$ & $1.528(5)$ & $\mathrm{C} 4 \mathrm{~A} \quad \mathrm{C} 5 \mathrm{~A}$ & $1.546(11)$ \\
\hline $\mathrm{C} 5$ & C6 & $1.322(5)$ & C5A C6A & $1.298(10)$ \\
\hline $\mathrm{C} 5$ & $\mathrm{C} 10$ & $1.525(4)$ & $\mathrm{C} 5 \mathrm{~A} \quad \mathrm{C} 10 \mathrm{~A}$ & $1.515(9)$ \\
\hline C6 & $\mathrm{C} 7$ & $1.494(3)$ & C6A C7A & $1.493(7)$ \\
\hline $\mathrm{C} 7$ & $\mathrm{C} 8$ & $1.533(3)$ & $\mathrm{C} 7 \mathrm{~A} \quad \mathrm{C} 8 \mathrm{~A}$ & $1.540(6)$ \\
\hline $\mathrm{C} 8$ & $\mathrm{C} 9$ & $1.542(3)$ & C8A C9A & $1.544(6)$ \\
\hline $\mathrm{C} 8$ & $\mathrm{C} 14$ & 1.515 (3) & $\mathrm{C} 8 \mathrm{~A} \quad \mathrm{C} 14 \mathrm{~A}$ & $1.521(6)$ \\
\hline C9 & $\mathrm{C} 10$ & $1.546(3)$ & $\mathrm{C} 9 \mathrm{~A} \quad \mathrm{C} 10 \mathrm{~A}$ & $1.574(6)$ \\
\hline C9 & $\mathrm{C} 11$ & $1.543(3)$ & C9A C11A & $1.535(6)$ \\
\hline $\mathrm{C} 10$ & $\mathrm{C} 18$ & $1.546(3)$ & C10A C18A & $1.539(6)$ \\
\hline $\mathrm{C} 11$ & $\mathrm{C} 12$ & $1.532(3)$ & $\mathrm{C} 11 \mathrm{AC} 12 \mathrm{~A}$ & $1.544(6)$ \\
\hline $\mathrm{C} 12$ & $\mathrm{C} 13$ & 1.527 ( 3 ) & $\mathrm{C} 12 \mathrm{AC} 13 \mathrm{~A}$ & $1.529(6)$ \\
\hline $\mathrm{C} 13$ & $\mathrm{C} 14$ & 1.541 (3) & C13A C14A & $1.534(6)$ \\
\hline $\mathrm{C} 13$ & $\mathrm{C} 17$ & 1.559 (3) & C13A C17A & $1.561(6)$ \\
\hline $\mathrm{C} 13$ & C19 & $1.529(4)$ & C13A C19A & $1.509(9)$ \\
\hline $\mathrm{C} 14$ & $\mathrm{C} 15$ & $1.525(3)$ & C14A C15A & $1.532(6)$ \\
\hline $\mathrm{C} 15$ & $\mathrm{C} 16$ & $1.548(3)$ & $\mathrm{C} 15 \mathrm{AC} 16 \mathrm{~A}$ & $1.533(7)$ \\
\hline $\mathrm{C} 16$ & $\mathrm{C} 17$ & $1.547(3)$ & C16A C17A & $1.545(7)$ \\
\hline $\mathrm{C} 17$ & $\mathrm{C} 20$ & $1.508(3)$ & $\mathrm{C} 17 \mathrm{AC} 20 \mathrm{~A}$ & $1.524(7)$ \\
\hline $\mathrm{C} 20$ & $\mathrm{C} 21$ & $1.503(3)$ & $\mathrm{C} 20 \mathrm{AC} 21 \mathrm{~A}$ & $1.512(7)$ \\
\hline $\mathrm{C} 22$ & $\mathrm{C} 23$ & $1.510(6)$ & $\mathrm{C} 22 \mathrm{~A} \mathrm{C} 23 \mathrm{~A}$ & $1.502(10)$ \\
\hline $\mathrm{C} 23$ & $\mathrm{C} 24$ & $1.379(7)$ & $\mathrm{C} 23 \mathrm{~A} \mathrm{C} 24 \mathrm{~A}$ & $1.401(11)$ \\
\hline $\mathrm{C} 23$ & $\mathrm{C} 28$ & $1.380(8)$ & $\mathrm{C} 23 \mathrm{~A} \mathrm{C} 28 \mathrm{~A}$ & $1.395(11)$ \\
\hline $\mathrm{C} 24$ & $\mathrm{C} 25$ & $1.384(3)$ & $\mathrm{C} 24 \mathrm{~A} C 25 \mathrm{~A}$ & $1.378(7)$ \\
\hline $\mathrm{C} 25$ & $\mathrm{C} 26$ & $1.370(7)$ & $\mathrm{C} 25 \mathrm{~A} \mathrm{C} 26 \mathrm{~A}$ & $1.335(10)$ \\
\hline $\mathrm{C} 26$ & $\mathrm{C} 27$ & $1.393(5)$ & $\mathrm{C} 26 \mathrm{~A}$ C27A & $1.388(9)$ \\
\hline $\mathrm{C} 27$ & $\mathrm{C} 28$ & $1.391(3)$ & $\mathrm{C} 27 \mathrm{AC} 28 \mathrm{~A}$ & $1.377(7)$ \\
\hline
\end{tabular}

\section{Table S12. Bond Angles for $3 \mathrm{e}$.}

\begin{tabular}{|c|c|c|c|c|c|}
\hline \multicolumn{3}{|c|}{ Atom Atom Atom } & \multirow{2}{*}{$\begin{array}{l}\text { Angle }^{\circ} \\
113.41(17)\end{array}$} & \multirow{2}{*}{$\begin{array}{l}\text { Atom Atom Atom } \\
\text { C22A O1A C } 3 \mathrm{~A}\end{array}$} & \multirow{2}{*}{$\begin{array}{l}\text { Angle }^{\circ} \\
\qquad 113.8(4)\end{array}$} \\
\hline $\mathrm{C} 22$ & $\mathrm{O} 1$ & $\mathrm{C} 3$ & & & \\
\hline $\mathrm{C} 26$ & $\mathrm{O} 3$ & $\mathrm{C} 29$ & $118.3(3)$ & C29A O3A C26A & $117.8(5)$ \\
\hline $\mathrm{C} 2$ & $\mathrm{C} 1$ & $\mathrm{C} 10$ & $114.15(18)$ & $\mathrm{C} 2 \mathrm{~A} \quad \mathrm{C} 1 \mathrm{~A} \quad \mathrm{C} 10 \mathrm{~A}$ & $114.2(4)$ \\
\hline $\mathrm{C} 1$ & $\mathrm{C} 2$ & $\mathrm{C} 3$ & $110.7(2)$ & $\mathrm{C} 3 \mathrm{~A} \quad \mathrm{C} 2 \mathrm{~A} \quad \mathrm{C} 1 \mathrm{~A}$ & $110.2(4)$ \\
\hline 01 & $\mathrm{C} 3$ & $\mathrm{C} 2$ & $112.39(18)$ & O1A C3A C2A & $112.7(4)$ \\
\hline
\end{tabular}




\begin{tabular}{|c|c|c|c|c|c|}
\hline $\mathrm{O} 1$ & $\mathrm{C} 3$ & $\mathrm{C} 4$ & $107.72(17)$ & O1A C3A C4A & $108.5(4)$ \\
\hline $\mathrm{C} 4$ & $\mathrm{C} 3$ & $\mathrm{C} 2$ & $108.59(18)$ & $\mathrm{C} 2 \mathrm{~A} \quad \mathrm{C} 3 \mathrm{~A} \quad \mathrm{C} 4 \mathrm{~A}$ & $109.9(4)$ \\
\hline $\mathrm{C} 3$ & $\mathrm{C} 4$ & $\mathrm{C} 5$ & $111.8(2)$ & C3A C4A C5A & $111.5(6)$ \\
\hline C6 & $\mathrm{C} 5$ & $\mathrm{C} 4$ & $120.3(3)$ & C6A C5A C4A & $119.0(7)$ \\
\hline C6 & $\mathrm{C} 5$ & $\mathrm{C} 10$ & $124.0(4)$ & C6A C5A C10A & $126.3(8)$ \\
\hline $\mathrm{C} 10$ & $\mathrm{C} 5$ & $\mathrm{C} 4$ & 115.7 ( 3 ) & C10AC5A C4A & $114.7(7)$ \\
\hline $\mathrm{C} 5$ & C6 & $\mathrm{C} 7$ & $124.7(2)$ & C5A C6A C7A & $123.8(6)$ \\
\hline C6 & $\mathrm{C} 7$ & $\mathrm{C} 8$ & $112.78(18)$ & C6A C7A C8A & $113.5(4)$ \\
\hline $\mathrm{C} 7$ & $\mathrm{C} 8$ & $\mathrm{C} 9$ & $110.31(17)$ & C7A C8A C9A & $108.8(4)$ \\
\hline $\mathrm{C} 14$ & $\mathrm{C} 8$ & $\mathrm{C} 7$ & $110.61(17)$ & C14AC8A C7A & $110.7(4)$ \\
\hline $\mathrm{C} 14$ & $\mathrm{C} 8$ & $\mathrm{C} 9$ & $109.02(16)$ & C14AC8A C9A & $108.5(4)$ \\
\hline $\mathrm{C} 8$ & $\mathrm{C} 9$ & $\mathrm{C} 10$ & $113.32(17)$ & C8A C9A C10A & $113.0(4)$ \\
\hline $\mathrm{C} 8$ & $\mathrm{C} 9$ & $\mathrm{C} 11$ & $110.85(17)$ & C11AC9A C8A & $111.9(4)$ \\
\hline $\mathrm{C} 11$ & C9 & $\mathrm{C} 10$ & $112.96(17)$ & C11AC9A C10A & $111.5(4)$ \\
\hline $\mathrm{C} 5$ & $\mathrm{C} 10$ & $\mathrm{C} 1$ & $108.4(2)$ & C1A C10A C9A & $107.8(4)$ \\
\hline $\mathrm{C} 5$ & $\mathrm{C} 10$ & C9 & $110.2(3)$ & C5A C10AC1A & $109.0(5)$ \\
\hline $\mathrm{C} 5$ & $\mathrm{C} 10$ & $\mathrm{C} 18$ & $108.7(3)$ & C5A C10AC9A & $108.3(6)$ \\
\hline C9 & $\mathrm{C} 10$ & $\mathrm{C} 1$ & $108.05(17)$ & C5A C10AC18A & $109.5(7)$ \\
\hline $\mathrm{C} 18$ & $\mathrm{C} 10$ & $\mathrm{C} 1$ & $109.49(19)$ & C18AC10AC1A & $110.1(4)$ \\
\hline $\mathrm{C} 18$ & $\mathrm{C} 10$ & C9 & $111.92(17)$ & C18A C10A C9A & $112.0(4)$ \\
\hline $\mathrm{C} 12$ & $\mathrm{C} 11$ & $\mathrm{C} 9$ & $114.23(18)$ & C9A C11AC12A & $113.1(4)$ \\
\hline $\mathrm{C} 13$ & $\mathrm{C} 12$ & $\mathrm{C} 11$ & $111.30(18)$ & $\mathrm{C} 13 \mathrm{~A} C 12 \mathrm{AC} 11 \mathrm{~A}$ & $111.4(4)$ \\
\hline $\mathrm{C} 12$ & $\mathrm{C} 13$ & $\mathrm{C} 14$ & $107.27(16)$ & C12A C13A C14A & $107.9(4)$ \\
\hline $\mathrm{C} 12$ & $\mathrm{C} 13$ & $\mathrm{C} 17$ & $116.20(18)$ & C12A C13A C17A & $116.2(4)$ \\
\hline $\mathrm{C} 12$ & $\mathrm{C} 13$ & $\mathrm{C} 19$ & $110.9(2)$ & C14A C13A C17A & $99.9(4)$ \\
\hline $\mathrm{C} 14$ & $\mathrm{C} 13$ & $\mathrm{C} 17$ & $99.76(16)$ & C19A C13A C12A & $110.4(6)$ \\
\hline $\mathrm{C} 19$ & $\mathrm{C} 13$ & $\mathrm{C} 14$ & $113.5(2)$ & C19A C13A C14A & $112.5(6)$ \\
\hline $\mathrm{C} 19$ & $\mathrm{C} 13$ & $\mathrm{C} 17$ & $108.9(2)$ & C19A C13A C17A & $109.5(6)$ \\
\hline $\mathrm{C} 8$ & $\mathrm{C} 14$ & $\mathrm{C} 13$ & $114.58(16)$ & C8A C14AC13A & $113.9(4)$ \\
\hline $\mathrm{C} 8$ & $\mathrm{C} 14$ & $\mathrm{C} 15$ & $119.34(18)$ & C8A C14AC15A & $119.5(4)$ \\
\hline $\mathrm{C} 15$ & $\mathrm{C} 14$ & $\mathrm{C} 13$ & $104.19(17)$ & C15A C14A C13A & $104.3(4)$ \\
\hline $\mathrm{C} 14$ & $\mathrm{C} 15$ & $\mathrm{C} 16$ & $104.00(18)$ & C14A C15A C16A & $103.9(4)$ \\
\hline $\mathrm{C} 17$ & $\mathrm{C} 16$ & $\mathrm{C} 15$ & $106.26(19)$ & C15A C16A C17A & $107.0(4)$ \\
\hline $\mathrm{C} 16$ & $\mathrm{C} 17$ & $\mathrm{C} 13$ & $104.87(18)$ & C16A C17A C13A & $104.5(4)$ \\
\hline $\mathrm{C} 20$ & $\mathrm{C} 17$ & $\mathrm{C} 13$ & $115.70(19)$ & C20A C17A C13A & $114.1(4)$ \\
\hline $\mathrm{C} 20$ & $\mathrm{C} 17$ & $\mathrm{C} 16$ & $114.5(2)$ & C20A C17A C16A & $114.5(4)$ \\
\hline $\mathrm{O} 2$ & $\mathrm{C} 20$ & $\mathrm{C} 17$ & $121.9(2)$ & O2A C20A C17A & $121.2(6)$ \\
\hline
\end{tabular}




$\begin{array}{llllll}\mathrm{O} 2 & \mathrm{C} 20 & \mathrm{C} 21 & 120.1(3) & \mathrm{O} 2 \mathrm{~A} C 20 \mathrm{AC} 21 \mathrm{~A} & 122.1(7) \\ \mathrm{C} 21 & \mathrm{C} 20 & \mathrm{C} 17 & 118.0(2) & \mathrm{C} 21 \mathrm{AC} 20 \mathrm{AC} 17 \mathrm{~A} & 116.6(5) \\ \mathrm{O} 1 & \mathrm{C} 22 & \mathrm{C} 23 & 109.2(3) & \mathrm{O} 1 \mathrm{~A} \mathrm{C} 22 \mathrm{AC} 23 \mathrm{~A} & 107.2(5) \\ \mathrm{C} 24 & \mathrm{C} 23 & \mathrm{C} 22 & 121.4(5) & \mathrm{C} 24 \mathrm{AC} 23 \mathrm{AC} 22 \mathrm{~A} & 121.8(8) \\ \mathrm{C} 24 & \mathrm{C} 23 & \mathrm{C} 28 & 118.9(5) & \mathrm{C} 28 \mathrm{AC} 23 \mathrm{AC} 22 \mathrm{~A} & 121.1(7) \\ \mathrm{C} 28 & \mathrm{C} 23 & \mathrm{C} 22 & 119.7(5) \mathrm{C} 28 \mathrm{AC} 23 \mathrm{AC} 24 \mathrm{~A} & 116.7(7) \\ \mathrm{C} 23 & \mathrm{C} 24 & \mathrm{C} 25 & 121.0(3) \mathrm{C} 25 \mathrm{AC} 24 \mathrm{AC} 23 \mathrm{~A} & 120.5(6) \\ \mathrm{C} 26 & \mathrm{C} 25 & \mathrm{C} 24 & 119.4(3) \mathrm{C} 26 \mathrm{AC} 25 \mathrm{AC} 24 \mathrm{~A} & 120.2(5) \\ \mathrm{O} 3 & \mathrm{C} 26 & \mathrm{C} 27 & 123.1(5) \mathrm{C} 25 \mathrm{AC} 26 \mathrm{~A} \mathrm{O} 3 \mathrm{~A} & 116.0(6) \\ \mathrm{C} 25 & \mathrm{C} 26 & \mathrm{O} 3 & 115.7(4) \mathrm{C} 25 \mathrm{AC} 26 \mathrm{AC} 27 \mathrm{~A} & 122.7(6) \\ \mathrm{C} 25 & \mathrm{C} 26 & \mathrm{C} 27 & 121.2(5) \mathrm{C} 27 \mathrm{AC} 26 \mathrm{~A} \mathrm{O} 3 \mathrm{~A} & 120.9(7) \\ \mathrm{C} 28 & \mathrm{C} 27 & \mathrm{C} 26 & 118.1(3) \mathrm{C} 28 \mathrm{AC} 27 \mathrm{AC} 26 \mathrm{~A} & 116.6(6) \\ \mathrm{C} 23 & \mathrm{C} 28 & \mathrm{C} 27 & 121.4(3) \mathrm{C} 27 \mathrm{AC} 28 \mathrm{AC} 23 \mathrm{~A} & 123.0(6)\end{array}$

Table S13. Torsion Angles for $3 e$.

\begin{tabular}{|c|c|c|c|c|c|c|}
\hline A & B $\quad$ C $\quad$ D & ngle $/^{\circ}$ & $\mathbf{A}$ & B & C & $/^{\circ}$ \\
\hline $\mathrm{O} 1$ & $\mathrm{C} 3 \mathrm{C} 4 \mathrm{C} 5$ & $178.7(3)$ & $\mathrm{O} 1 \mathrm{~A}$ & $\mathrm{C} 3 \mathrm{~A}$ & $\mathrm{C} 4 \mathrm{~A} \quad \mathrm{C} 5 \mathrm{~A}$ & -179.7 \\
\hline & $\mathrm{C} 22 \mathrm{C} 23 \mathrm{C} 24$ & $116.9(4)$ & $\mathrm{O} 1 \mathrm{~A}$ & $\mathrm{C} 22 \mathrm{~A}$ & $\mathrm{C} 23 \mathrm{~A} \mathrm{C} 24 \mathrm{~A}$ & $124.3(7)$ \\
\hline 1 & $\mathrm{C} 22 \mathrm{C}^{2}$ & $-65.3(5)$ & O1A & $\mathrm{C} 22 \mathrm{~A}$ & $\mathrm{C} 23$ & 9) \\
\hline $\mathrm{O} 3$ & $\mathrm{C} 26 \mathrm{C} 27 \mathrm{C} 28$ & ( 4 ) & O3A & $\mathrm{C} 26 \mathrm{~A}$ & $\mathrm{C} 27 \mathrm{AC}$ & -1 \\
\hline C1 & $\mathrm{C} 2 \quad \mathrm{C} 3 \quad \mathrm{O} 1$ & $77.92(18)$ & $\mathrm{C} 1 \mathrm{~A}$ & $\mathrm{C} 2 \mathrm{~A}$ & $\mathrm{C} 3 \mathrm{~A} \quad \mathrm{O} 1 \mathrm{~A}$ & 179. \\
\hline 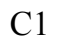 & $\mathrm{C} 2 \mathrm{C} 3 \mathrm{C} 4$ & $58.8(3)$ & $\mathrm{C} 1 \mathrm{~A}$ & $\mathrm{C} 2 \mathrm{~A}$ & $\mathrm{C} 3 \mathrm{~A} \quad \mathrm{C} 4 \mathrm{~A}$ & 58 \\
\hline 2 & $\mathrm{C} 1 \mathrm{C} 10 \mathrm{C} 5$ & $50.1(4)$ & $\mathrm{C} 2 \mathrm{~A}$ & $\mathrm{C} 1 \mathrm{~A}$ & C10AC & 51 \\
\hline $\mathrm{C} 2$ & C1 C10C9 & $69.50(18)$ & $\mathrm{C} 2 \mathrm{~A}$ & $\mathrm{C} 1 \mathrm{~A}$ & C10A C9A & $16 \varepsilon$ \\
\hline 2 & $\mathrm{C} 1 \mathrm{C} 10 \mathrm{C} 18$ & $-68.4(2)$ & $\mathrm{C} 2 \mathrm{~A}$ & $\mathrm{C} 1 \mathrm{~A}$ & C10A C18A & -6 \\
\hline 2 & $\mathrm{C} 3 \mathrm{C} 4 \mathrm{C} 5$ & $-56.7(3)$ & $\mathrm{C} 2 \mathrm{~A}$ & $\mathrm{C} 3 \mathrm{~A}$ & C4A C5A & $-56.1(7)$ \\
\hline 3 & $\mathrm{O} 1 \mathrm{C} 22 \mathrm{C} 23$ & $76.5(3)$ & $\mathrm{C} 3 \mathrm{~A}$ & O1A & $\mathrm{C} 22 \mathrm{~A} \mathrm{C} 23 \mathrm{~A}$ & 17 \\
\hline 3 & $\mathrm{C} 4 \mathrm{C} 5 \mathrm{C} 6$ & $-125.8(4)$ & $\mathrm{C} 3 \mathrm{~A}$ & $\mathrm{C} 4 \mathrm{~A}$ & C5A C6A & $-126.9(10)$ \\
\hline 3 & C4 $\mathrm{C} 5 \mathrm{C} 10$ & $54.0(5)$ & $\mathrm{C} 3 \mathrm{~A}$ & $\mathrm{C} 4 \mathrm{~A}$ & C5A C10A & 531 \\
\hline 4 & C5 $\quad$ C6 $\mathrm{C} 7$ & $-179.7(3)$ & $\mathrm{C} 4 \mathrm{~A}$ & $\mathrm{C} 5 \mathrm{~A}$ & C6A C7A & -17 \\
\hline $\mathrm{C} 4$ & $\mathrm{C} 5 \mathrm{C} 10 \mathrm{C} 1$ & $-48.2(5)$ & $\mathrm{C} 4 \mathrm{~A}$ & $\mathrm{C} 5 \mathrm{~A}$ & $\mathrm{C} 10 \mathrm{AC} 1 \mathrm{~A}$ & $-48 \cdot 7(11)$ \\
\hline $\mathrm{C} 4$ & C5 C10C9 & $-166.2(3)$ & $\mathrm{C} 4 \mathrm{~A}$ & $\mathrm{C} 5 \mathrm{~A}$ & C10A C9A & -16 \\
\hline 4 & C5 C10C18 & $70.8(4)$ & $\mathrm{C} 4 \mathrm{~A}$ & $\mathrm{C} 5 \mathrm{~A}$ & C10A C18A & 71.9 \\
\hline $\mathrm{C} 5$ & $\mathrm{C} 6 \mathrm{C} 7 \mathrm{C} 8$ & 14 & $\mathrm{C} 5 \mathrm{~A}$ & C6A & C7A C8A & 14 \\
\hline C6 & $\mathrm{C} 5 \mathrm{C} 10 \mathrm{C} 1$ & 131 & C6A & $\mathrm{C} 5 \mathrm{~A}$ & C10A C & 131 \\
\hline o & C5 C10C9 & $13.5(6)$ & C6A & $\mathrm{C} 5 \mathrm{~A}$ & C10A C9A & 14.31 \\
\hline
\end{tabular}




\begin{tabular}{|c|c|c|c|c|}
\hline $6 \mathrm{C} 5$ & c & -109.5 & C6A C5A C10 & 10 \\
\hline $\mathrm{C} 6 \mathrm{C} 7$ & C8 C9 & $-42.2(3)$ & C6A C7A C8A C9A & -43.0( \\
\hline $6 \mathrm{C} 7$ & $\mathrm{C} 8 \mathrm{C} 14$ & $-162.86(17)$ & C6A C7A C8A C14A & -162.1 \\
\hline $7 \mathrm{C} 8$ & C9 $\mathrm{C} 10$ & $58.3(2)$ & C7A C8A C9A C10A & 598 \\
\hline $\mathrm{C} 8$ & C9 C11 & -173 & C7A C8A C9A C11A & -17 \\
\hline $7 \mathrm{C} 8$ & $\mathrm{C} 14 \mathrm{C} 13$ & $-179.47(18)$ & C7A C8A C14AC13A & 178 . \\
\hline $\mathrm{C} 7 \mathrm{C} 8$ & $\mathrm{C} 14 \mathrm{C} 15$ & $-55.0(2)$ & C7A C8A C14AC15A & -5 \\
\hline C9 & $\mathrm{C} 10 \mathrm{C} 1$ & 160.98 & C8A C9A C10AC1A & \pm \\
\hline $8 \mathrm{C} 9$ & $\mathrm{C} 10 \mathrm{C} 5$ & $-42 \cdot 7(3)$ & C8A C9A C10AC5A & -4 \\
\hline C9 & $\mathrm{C} 10 \mathrm{C} 18$ & $78.4(2)$ & C8A C9A C10AC18A & 76 \\
\hline C9 & $\mathrm{C} 11 \mathrm{C} 12$ & (2) & C8A C9A C11A & 5 \\
\hline $8 \mathrm{C}$ & $4 \mathrm{C} 15 \mathrm{C} 16$ & $-165.82(18)$ & C8A C14AC15A C16A & -16 \\
\hline $\mathrm{C} 8$ & $\mathrm{C} 14 \mathrm{C} 13$ & $59.1(2)$ & C9A C8A C14AC13A & 59 \\
\hline $9 \mathrm{C} 8$ & $\mathrm{C} 14 \mathrm{C} 15$ & $-176.44(17)$ & C9A C8A C14AC15A & -176 \\
\hline $9 \mathrm{C} 11$ & $1 \mathrm{C} 12 \mathrm{C} 13$ & $-54.2(2)$ & C9A C11A C12A C13A & -53.5 \\
\hline $0 \mathrm{C} 1$ & $\mathrm{C} 2 \mathrm{C} 3$ & -57 & $\mathrm{C} 10 \mathrm{AC} 1 \mathrm{~A} \quad \mathrm{C} 2 \mathrm{~A} \quad \mathrm{C} 3 \mathrm{~A}$ & -5 \\
\hline $10 \mathrm{C} 5$ & $\mathrm{C} 6 \mathrm{C} 7$ & $0.6(7)$ & C10A C5A C6A C7A & 0 . \\
\hline $10 \mathrm{C} 9$ & $\mathrm{C} 11 \mathrm{C} 12$ & $-179.97(16)$ & C10A C9A C11AC12A & 179 \\
\hline $11 \mathrm{C} 9$ & $\mathrm{C} 10 \mathrm{C} 1$ & $71.9(2)$ & C11AC9A C10AC1A & 70 \\
\hline $11 \mathrm{C} 9$ & $\mathrm{C} 10 \mathrm{C} 5$ & $-169.8(3)$ & C11AC9A C10AC5 & -17 \\
\hline $11 \mathrm{C} 9$ & $\mathrm{C} 10 \mathrm{C} 18$ & $-48 \cdot 7(2)$ & C11AC9A C10AC18A & -50 \\
\hline $11 \mathrm{C}$ & $2 \mathrm{C} 13 \mathrm{C}$ & $55.1(2)$ & $\mathrm{C} 11 \mathrm{AC} 12 \mathrm{AC}$ & 5 \\
\hline $11 \mathrm{C} 12$ & $2 \mathrm{C} 13 \mathrm{C} 17$ & 65.69 & $\mathrm{C} 11 \mathrm{AC} 12 \mathrm{AC}$ & 166 \\
\hline $11 \mathrm{C}$ & $2 \mathrm{C} 13 \mathrm{C} 19$ & $-69.2(3)$ & $\mathrm{C} 11 \mathrm{AC} 12 \mathrm{AC} 1$ & -6 \\
\hline $12 \mathrm{Cl}$ & $3 \mathrm{C} 14 \mathrm{C} 8$ & $-60.4(2)$ & C12A C13A C14A C8 & -60 \\
\hline . & $3 \mathrm{C} 14 \mathrm{Cl}$ & 167 & $\mathrm{C} 1$ & 16 \\
\hline $12 \mathrm{C} 13$ & $3 \mathrm{C} 17 \mathrm{C} 16$ & $-152.53(19)$ & C12A C13A C17A C16A & \\
\hline $12 \mathrm{C} 1$ & $3 \mathrm{C} 17 \mathrm{C} 20$ & $80.3(2)$ & C12A C13A C17A C20A & 81 \\
\hline $3 \mathrm{C} 14$ & $4 \mathrm{C} 15 \mathrm{Cl}$ & -36 & C13A C14A C15A C1 & \\
\hline 130 & $7 \mathrm{C} 20 \mathrm{O} 2$ & 113 & C13A C17A C20A & \\
\hline $13 \mathrm{C17}$ & $7 \mathrm{C} 20 \mathrm{C}$ & $-66.9(3)$ & C13A C17AC & 7) \\
\hline $14 \mathrm{C} 8$ & C9 C10 & $179.97(15)$ & C14AC8A C9A C10A & -1 \\
\hline $14 \mathrm{C} 8$ & C9 C11 & -51 & C14AC8A C9A C11A & -5 \\
\hline $\mathrm{C} 1$ & $\mathrm{C} 16$ & 2) & $\mathrm{C} 1$ & - \\
\hline $\mathrm{C} 14 \mathrm{C}$ & $3 \mathrm{C} 17 \mathrm{C} 20$ & $64.88(18)$ & C14A C13A C17A C20A & -1 \\
\hline 14 & $5 \mathrm{C} 16 \mathrm{C}$ & 12 & C14A C15A C16A C17A & 11 \\
\hline 12 & $5 \mathrm{Cl}$ & $16.4(2)$ & C15A C & 10 \\
\hline
\end{tabular}




\begin{tabular}{|c|c|c|c|}
\hline $6 \mathrm{C} 17 \mathrm{C} 20$ & (2) & C15A C16A C17A C 2 & 1 \\
\hline $\mathrm{C} 16 \mathrm{C} 17 \mathrm{C} 20 \mathrm{O} 2$ & $-8.3(4)$ & C16A C17A C20A O2A & $-10 \cdot 3(10)$ \\
\hline $\mathrm{C} 16 \mathrm{C} 17 \mathrm{C} 20 \mathrm{C} 21$ & $170.9(2)$ & C16A C17A C20A C21A & $169.1(5)$ \\
\hline $\mathrm{C} 17 \mathrm{C} 13 \mathrm{C} 14 \mathrm{C} 8$ & $8.07(16)$ & C17A C13A C14A C8A & 177 \\
\hline $17 \mathrm{C} 13 \mathrm{C} 14 \mathrm{C} 15$ & $45.9(2)$ & C17A C13A C14A C15A & 70 \\
\hline $\mathrm{C} 19 \mathrm{C} 13 \mathrm{C} 14 \mathrm{C} 8$ & $62.4(3)$ & C19A C13A C14A C8A & $61.3(7)$ \\
\hline $\mathrm{C} 19 \mathrm{C} 13 \mathrm{C} 14 \mathrm{C} 15$ & $-69.8(3)$ & C19A C13A C14A C15A & $-70.6(7)$ \\
\hline $19 \mathrm{C} 13 \mathrm{C} 17 \mathrm{C} 16$ & $81.4(3)$ & C19A C13A C17A C16A & $80.8(7)$ \\
\hline $\mathrm{C} 19 \mathrm{C} 13 \mathrm{C} 17 \mathrm{C} 20$ & $-45.8(3)$ & C19A C13A C17A C20A & $-45.0(7)$ \\
\hline $\mathrm{C} 22 \mathrm{O} 1 \mathrm{C} 3 \quad \mathrm{C} 2$ & (2) & $\mathrm{C} 22 \mathrm{AO} 1 \mathrm{~A} \quad \mathrm{C} 3 \mathrm{~A} \quad \mathrm{C} 2 \mathrm{~A}$ & $70.2(6)$ \\
\hline $\mathrm{C} 22 \mathrm{O} 1 \mathrm{C} 3 \mathrm{C} 4$ & $166.3(2)$ & $\mathrm{C} 22 \mathrm{AO} 1 \mathrm{~A} \quad \mathrm{C} 3 \mathrm{~A} \quad \mathrm{C} 4 \mathrm{~A}$ & $-167.9(5)$ \\
\hline $\mathrm{C} 22 \mathrm{C} 23 \mathrm{C} 24 \mathrm{C} 25$ & $178.4(3)$ & $\mathrm{C} 22 \mathrm{~A}$ C23A C24A C $25 \mathrm{~A}$ & $178.0(6)$ \\
\hline $\mathrm{C} 22 \mathrm{C} 23 \mathrm{C} 28 \mathrm{C} 27$ & $-178 \cdot 7(3)$ & $\mathrm{C} 22 \mathrm{~A}$ C23A C28A C27A & $-177.8(6)$ \\
\hline $\mathrm{C} 23 \mathrm{C} 24 \mathrm{C} 25 \mathrm{C} 26$ & -0 . & $\mathrm{C} 23 \mathrm{~A} C 24 \mathrm{~A} \mathrm{C} 25 \mathrm{~A} \mathrm{C} 26 \mathrm{~A}$ & -4 \\
\hline $\mathrm{C} 24 \mathrm{C} 23 \mathrm{C} 28 \mathrm{C} 27$ & $-0.8(6)$ & $\mathrm{C} 24 \mathrm{~A}$ C23A C28A C27A & $-4.5(10)$ \\
\hline $\mathrm{C} 24 \mathrm{C} 25 \mathrm{C} 26 \mathrm{O} 3$ & $-179.5(3)$ & C24A C25A C26A O3A & $177.2(5)$ \\
\hline $\mathrm{C} 24 \mathrm{C} 25 \mathrm{C} 26 \mathrm{C} 27$ & $1.2(6)$ & C24A C25A C26A C27A & 4.5( \\
\hline $\mathrm{C} 25 \mathrm{C} 26 \mathrm{C} 27 \mathrm{C} 28$ & $-1.4(6)$ & $\mathrm{C} 25 \mathrm{~A}$ C26A C27A C28A & $-3.9(10)$ \\
\hline $\mathrm{C} 26 \mathrm{C} 27 \mathrm{C} 28 \mathrm{C} 23$ & $1.2(5)$ & $\mathrm{C} 26 \mathrm{~A}$ C27A C28A C23A & $3.9(9)$ \\
\hline $\mathrm{C} 28 \mathrm{C} 23 \mathrm{C} 24 \mathrm{C} 25$ & $0.6(6)$ & $\mathrm{C} 28 \mathrm{~A} \mathrm{C} 23 \mathrm{~A} \mathrm{C} 24 \mathrm{~A} \mathrm{C} 2$ & $4.8(9)$ \\
\hline $\mathrm{C} 29 \mathrm{O} 3 \mathrm{C} 26 \mathrm{C} 25$ & $174.9(3)$ & C29A O3A C26AC25A & $173.7(6)$ \\
\hline $\mathrm{C} 29 \mathrm{O} 3 \mathrm{C} 26 \mathrm{C} 27$ & $-5.8(6)$ & C29A O3A C26A C27A & $-13.4(5$ \\
\hline
\end{tabular}

Table S14. Hydrogen Atom Coordinates $\left(\AA \times 10^{4}\right)$ and Isotropic Displacement Parameters $\left(\AA^{2} \times 10^{3}\right)$ for $3 \mathrm{e}$.

\begin{tabular}{lrrrr} 
Atom & \multicolumn{2}{c}{$\boldsymbol{y}$} & $\boldsymbol{U}(\mathbf{e q})$ \\
H1A & 6401 & 7893 & 578 & 43 \\
H1B & 5410 & 6592 & 417 & 43 \\
H2A & 5358 & 7178 & 2303 & 45 \\
H2B & 6671 & 7529 & 2496 & 45 \\
H3 & 4843 & 5214 & 2109 & 40 \\
H4A & 6251 & 4682 & 2396 & 39 \\
H4B & 7212 & 5991 & 2594 & 39 \\
H6 & 6491 & 4072 & 670 & 40 \\
H7A & 6187 & 4345 & -1388 & 41 \\
H7B & 7407 & 4465 & -1128 & 41 \\
H8 & 8347 & 6422 & -1246 & 34
\end{tabular}




\begin{tabular}{|c|c|c|c|c|}
\hline H9 & 6150 & 6275 & -1145 & 35 \\
\hline H11A & 7050 & 8266 & -1238 & 40 \\
\hline H11B & 8285 & 8375 & -1278 & 40 \\
\hline $\mathrm{H} 12 \mathrm{~A}$ & 6618 & 7473 & -3081 & 41 \\
\hline H12B & 7819 & 8645 & -3135 & 41 \\
\hline H14 & 6575 & 5670 & -2914 & 36 \\
\hline $\mathrm{H} 15 \mathrm{~A}$ & 7268 & 4505 & -3405 & 42 \\
\hline H15B & 8579 & 5490 & -3204 & 42 \\
\hline H16A & 8605 & 5964 & -5063 & 48 \\
\hline H16B & 7237 & 5178 & -5165 & 48 \\
\hline H17 & 6925 & 6603 & -4741 & 42 \\
\hline H18A & 8380 & 8452 & 632 & 56 \\
\hline H18B & 8828 & 7570 & 422 & 56 \\
\hline $\mathrm{H} 18 \mathrm{C}$ & 8295 & 7605 & 1636 & 56 \\
\hline H19A & 9606 & 8640 & -3491 & 52 \\
\hline H19B & 9640 & 7470 & -3471 & 52 \\
\hline H19C & 9455 & 7981 & -2306 & 52 \\
\hline $\mathrm{H} 21 \mathrm{~A}$ & 8620 & 9298 & -4897 & 74 \\
\hline $\mathrm{H} 21 \mathrm{~B}$ & 7419 & 8498 & -5516 & 74 \\
\hline $\mathrm{H} 21 \mathrm{C}$ & 8561 & 9182 & -6264 & 74 \\
\hline $\mathrm{H} 22 \mathrm{~A}$ & 3739 & 5000 & 3698 & 54 \\
\hline $\mathrm{H} 22 \mathrm{~B}$ & 4460 & 6354 & 3923 & 54 \\
\hline $\mathrm{H} 24$ & 4444 & 6915 & 5838 & 47 \\
\hline H25 & 4224 & 6556 & 7803 & 46 \\
\hline $\mathrm{H} 27$ & 3875 & 3430 & 7257 & 47 \\
\hline H28 & 4087 & 3811 & 5284 & 49 \\
\hline H29A & 2901 & 3130 & 8972 & 72 \\
\hline H29B & 3453 & 3727 & 10171 & 72 \\
\hline $\mathrm{H} 29 \mathrm{C}$ & 4227 & 3586 & 9218 & 72 \\
\hline H1AA & 6874 & 8139 & 1442 & 48 \\
\hline $\mathrm{H} 1 \mathrm{AB}$ & 7863 & 7826 & 1586 & 48 \\
\hline $\mathrm{H} 2 \mathrm{AA}$ & 6600 & 7530 & -482 & 51 \\
\hline $\mathrm{H} 2 \mathrm{AB}$ & 7915 & 8484 & -285 & 51 \\
\hline $\mathrm{H} 3 \mathrm{~A}$ & 8414 & 7041 & -97 & 46 \\
\hline $\mathrm{H} 4 \mathrm{AA}$ & 7039 & 5101 & -404 & 51 \\
\hline $\mathrm{H} 4 \mathrm{AB}$ & 6060 & 5425 & -597 & 51 \\
\hline H6A & 6787 & 4237 & 1285 & 47 \\
\hline
\end{tabular}




\begin{tabular}{|c|c|c|c|c|}
\hline H7AA & 7088 & 4784 & 3353 & 49 \\
\hline H7AB & 5873 & 3684 & 3083 & 49 \\
\hline H8A & 4918 & 4699 & 3246 & 42 \\
\hline H9A & 7141 & 6732 & 3155 & 42 \\
\hline $\mathrm{H} 11 \mathrm{C}$ & 5040 & 6762 & 3295 & 48 \\
\hline H11D & 6293 & 7866 & 3259 & 48 \\
\hline $\mathrm{H} 12 \mathrm{C}$ & 6713 & 7470 & 5101 & 41 \\
\hline H12D & 5526 & 7466 & 5174 & 41 \\
\hline H14A & 6710 & 5681 & 4911 & 41 \\
\hline $\mathrm{H} 15 \mathrm{C}$ & 5978 & 3813 & 5404 & 48 \\
\hline H15D & 4675 & 3513 & 5199 & 48 \\
\hline $\mathrm{H} 16 \mathrm{C}$ & 6011 & 4503 & 7156 & 57 \\
\hline H16D & 4649 & 3956 & 7044 & 57 \\
\hline H17A & 6372 & 6268 & 6771 & 44 \\
\hline H18D & 4880 & 6700 & 1420 & 60 \\
\hline $\mathrm{H} 18 \mathrm{E}$ & 4449 & 5367 & 1585 & 60 \\
\hline $\mathrm{H} 18 \mathrm{~F}$ & 4969 & 5973 & 381 & 60 \\
\hline H19D & 3727 & 5676 & 5506 & 51 \\
\hline H19E & 3679 & 4468 & 5423 & 51 \\
\hline H19F & 3893 & 5223 & 4294 & 51 \\
\hline $\mathrm{H} 21 \mathrm{D}$ & 4688 & 7328 & 6969 & 83 \\
\hline $\mathrm{H} 21 \mathrm{E}$ & 5922 & 7673 & 7476 & 83 \\
\hline $\mathrm{H} 21 \mathrm{~F}$ & 4854 & 7273 & 8321 & 83 \\
\hline $\mathrm{H} 22 \mathrm{C}$ & 9536 & 8019 & -1669 & 63 \\
\hline $\mathrm{H} 22 \mathrm{D}$ & 8758 & 8591 & -1909 & 63 \\
\hline $\mathrm{H} 24 \mathrm{~A}$ & 8943 & 9247 & -3851 & 49 \\
\hline $\mathrm{H} 25 \mathrm{~A}$ & 9111 & 9022 & -5804 & 56 \\
\hline $\mathrm{H} 27 \mathrm{~A}$ & 9357 & 6213 & -5218 & 55 \\
\hline $\mathrm{H} 28 \mathrm{~A}$ & 9163 & 6415 & -3261 & 51 \\
\hline H29D & 9933 & 6973 & -8090 & 76 \\
\hline H29E & 9012 & 6014 & -7255 & 76 \\
\hline $\mathrm{H} 29 \mathrm{~F}$ & 10302 & 6816 & -6830 & 76 \\
\hline
\end{tabular}

Table S15. Atomic Occupancy for $3 e$.

$\begin{array}{lclclc}\text { Atom } & \text { Occupancy } & \text { Atom } & \text { Occupancy } & \text { Atom } & \text { Occupancy } \\ \mathrm{O} 1 & 0.6759(13) & \mathrm{O} 2 & 0.6759(13) & \mathrm{O} 3 & 0.6759(13) \\ & & & & \\ & & & & \\ & & & \end{array}$




\begin{tabular}{|c|c|c|c|c|c|}
\hline $\mathrm{C} 1$ & $0.6759(13)$ & H1A & $0.6759(13)$ & H1B & $0.6759(13)$ \\
\hline $\mathrm{C} 2$ & $0.6759(13)$ & $\mathrm{H} 2 \mathrm{~A}$ & $0.6759(13)$ & $\mathrm{H} 2 \mathrm{~B}$ & $0.6759(13)$ \\
\hline $\mathrm{C} 3$ & $0.6759(13)$ & $\mathrm{H} 3$ & $0.6759(13)$ & $\mathrm{C} 4$ & $0.6759(13)$ \\
\hline $\mathrm{H} 4 \mathrm{~A}$ & $0.6759(13)$ & H4B & $0.6759(13)$ & $\mathrm{C} 5$ & $0.6759(13)$ \\
\hline C6 & $0.6759(13)$ & H6 & $0.6759(13)$ & $\mathrm{C} 7$ & $0.6759(13)$ \\
\hline H7A & $0.6759(13)$ & H7B & $0.6759(13)$ & $\mathrm{C} 8$ & $0.6759(13)$ \\
\hline $\mathrm{H} 8$ & $0.6759(13)$ & C9 & $0.6759(13)$ & H9 & $0.6759(13)$ \\
\hline $\mathrm{C} 10$ & $0.6759(13)$ & $\mathrm{C} 11$ & $0.6759(13)$ & $\mathrm{H} 11 \mathrm{~A}$ & $0.6759(13)$ \\
\hline H11B & $0.6759(13)$ & $\mathrm{C} 12$ & $0.6759(13)$ & $\mathrm{H} 12 \mathrm{~A}$ & $0.6759(13)$ \\
\hline H12B & $0.6759(13)$ & $\mathrm{C} 13$ & $0.6759(13)$ & $\mathrm{C} 14$ & $0.6759(13)$ \\
\hline H14 & $0.6759(13)$ & $\mathrm{C} 15$ & $0.6759(13)$ & $\mathrm{H} 15 \mathrm{~A}$ & $0.6759(13)$ \\
\hline H15B & $0.6759(13)$ & $\mathrm{C} 16$ & $0.6759(13)$ & $\mathrm{H} 16 \mathrm{~A}$ & $0.6759(13)$ \\
\hline H16B & $0.6759(13)$ & $\mathrm{C} 17$ & $0.6759(13)$ & H17 & $0.6759(13)$ \\
\hline $\mathrm{C} 18$ & $0.6759(13)$ & H18A & $0.6759(13)$ & H18B & $0.6759(13)$ \\
\hline $\mathrm{H} 18 \mathrm{C}$ & $0.6759(13)$ & $\mathrm{C} 19$ & $0.6759(13)$ & H19A & $0.6759(13)$ \\
\hline H19B & $0.6759(13)$ & $\mathrm{H} 19 \mathrm{C}$ & $0.6759(13)$ & $\mathrm{C} 20$ & $0.6759(13)$ \\
\hline $\mathrm{C} 21$ & $0.6759(13)$ & $\mathrm{H} 21 \mathrm{~A}$ & $0.6759(13)$ & $\mathrm{H} 21 \mathrm{~B}$ & $0.6759(13)$ \\
\hline $\mathrm{H} 21 \mathrm{C}$ & $0.6759(13)$ & $\mathrm{C} 22$ & $0.6759(13)$ & $\mathrm{H} 22 \mathrm{~A}$ & $0.6759(13)$ \\
\hline $\mathrm{H} 22 \mathrm{~B}$ & $0.6759(13)$ & $\mathrm{C} 23$ & $0.6759(13)$ & $\mathrm{C} 24$ & $0.6759(13)$ \\
\hline $\mathrm{H} 24$ & $0.6759(13)$ & $\mathrm{C} 25$ & $0.6759(13)$ & $\mathrm{H} 25$ & $0.6759(13)$ \\
\hline $\mathrm{C} 26$ & $0.6759(13)$ & $\mathrm{C} 27$ & $0.6759(13)$ & $\mathrm{H} 27$ & $0.6759(13)$ \\
\hline $\mathrm{C} 28$ & $0.6759(13)$ & $\mathrm{H} 28$ & $0.6759(13)$ & $\mathrm{C} 29$ & $0.6759(13)$ \\
\hline $\mathrm{H} 29 \mathrm{~A}$ & $0.6759(13)$ & Н29B & $0.6759(13)$ & $\mathrm{H} 29 \mathrm{C}$ & $0.6759(13)$ \\
\hline O1A & $0.3241(13)$ & $\mathrm{O} 2 \mathrm{~A}$ & $0.3241(13)$ & $\mathrm{O} 3 \mathrm{~A}$ & $0.3241(13)$ \\
\hline $\mathrm{C} 1 \mathrm{~A}$ & $0.3241(13)$ & H1AA & $0.3241(13)$ & $\mathrm{H} 1 \mathrm{AB}$ & $0.3241(13)$ \\
\hline $\mathrm{C} 2 \mathrm{~A}$ & $0.3241(13)$ & $\mathrm{H} 2 \mathrm{AA}$ & $0.3241(13)$ & $\mathrm{H} 2 \mathrm{AB}$ & $0.3241(13)$ \\
\hline $\mathrm{C} 3 \mathrm{~A}$ & $0.3241(13)$ & $\mathrm{H} 3 \mathrm{~A}$ & $0.3241(13)$ & $\mathrm{C} 4 \mathrm{~A}$ & $0.3241(13)$ \\
\hline H4AA & $0.3241(13)$ & $\mathrm{H} 4 \mathrm{AB}$ & $0.3241(13)$ & $\mathrm{C} 5 \mathrm{~A}$ & $0.3241(13)$ \\
\hline C6A & $0.3241(13)$ & H6A & $0.3241(13)$ & C7A & $0.3241(13)$ \\
\hline H7AA & $0.3241(13)$ & $\mathrm{H} 7 \mathrm{AB}$ & $0.3241(13)$ & $\mathrm{C} 8 \mathrm{~A}$ & $0.3241(13)$ \\
\hline H8A & $0.3241(13)$ & C9A & $0.3241(13)$ & H9A & $0.3241(13)$ \\
\hline $\mathrm{C} 10 \mathrm{~A}$ & $0.3241(13)$ & $\mathrm{C} 11 \mathrm{~A}$ & $0.3241(13)$ & $\mathrm{H} 11 \mathrm{C}$ & $0.3241(13)$ \\
\hline H11D & $0.3241(13)$ & $\mathrm{C} 12 \mathrm{~A}$ & $0.3241(13)$ & $\mathrm{H} 12 \mathrm{C}$ & $0.3241(13)$ \\
\hline H12D & $0.3241(13)$ & $\mathrm{C} 13 \mathrm{~A}$ & $0.3241(13)$ & $\mathrm{C} 14 \mathrm{~A}$ & $0.3241(13)$ \\
\hline H14A & $0.3241(13)$ & $\mathrm{C} 15 \mathrm{~A}$ & $0.3241(13)$ & $\mathrm{H} 15 \mathrm{C}$ & $0.3241(13)$ \\
\hline H15D & $0.3241(13)$ & $\mathrm{C} 16 \mathrm{~A}$ & $0.3241(13)$ & H16C & $0.3241(13)$ \\
\hline H16D & $0.3241(13)$ & $\mathrm{C} 17 \mathrm{~A}$ & $0.3241(13)$ & H17A & $0.3241(13)$ \\
\hline
\end{tabular}




$\begin{array}{lllll}\text { C18A } & 0.3241(13) \mathrm{H} 18 \mathrm{D} & 0.3241(13) \mathrm{H} 18 \mathrm{E} & 0.3241(13) \\ \mathrm{H} 18 \mathrm{~F} & 0.3241(13) \mathrm{C} 19 \mathrm{~A} & 0.3241(13) \mathrm{H} 19 \mathrm{D} & 0.3241(13) \\ \mathrm{H} 19 \mathrm{E} & 0.3241(13) \mathrm{H} 19 \mathrm{~F} & 0.3241(13) \mathrm{C} 20 \mathrm{~A} & 0.3241(13) \\ \mathrm{C} 21 \mathrm{~A} & 0.3241(13) \mathrm{H} 21 \mathrm{D} & 0.3241(13) \mathrm{H} 21 \mathrm{E} & 0.3241(13) \\ \mathrm{H} 21 \mathrm{~F} & 0.3241(13) \mathrm{C} 22 \mathrm{~A} & 0.3241(13) \mathrm{H} 22 \mathrm{C} & 0.3241(13) \\ \mathrm{H} 22 \mathrm{D} & 0.3241(13) \mathrm{C} 23 \mathrm{~A} & 0.3241(13) \mathrm{C} 24 \mathrm{~A} & 0.3241(13) \\ \mathrm{H} 24 \mathrm{~A} & 0.3241(13) \mathrm{C} 25 \mathrm{~A} & 0.3241(13) \mathrm{H} 25 \mathrm{~A} & 0.3241(13) \\ \mathrm{C} 26 \mathrm{~A} & 0.3241(13) \mathrm{C} 27 \mathrm{~A} & 0.3241(13) \mathrm{H} 27 \mathrm{~A} & 0.3241(13) \\ \mathrm{C} 28 \mathrm{~A} & 0.3241(13) \mathrm{H} 28 \mathrm{~A} & 0.3241(13) \mathrm{C} 29 \mathrm{~A} & 0.3241(13) \\ \mathrm{H} 29 \mathrm{D} & 0.3241(13) \mathrm{H} 29 \mathrm{E} & 0.3241(13) \mathrm{H} 29 \mathrm{~F} & 0.3241(13)\end{array}$


Table S16. Crystal data and structure refinement for $4 \mathrm{c}$.

Identification code

Empirical formula

Formula weight

Temperature/K

Crystal system

Space group

$\mathrm{a} / \AA$

$\mathrm{b} / \AA$

$\mathrm{c} / \AA$

$\alpha /{ }^{\circ}$

$\beta /{ }^{\circ}$

$\gamma /{ }^{\circ}$

Volume $/ \AA^{3}$

Z

$\rho_{\text {calc }} \mathrm{g} / \mathrm{cm}^{3}$

$\mu / \mathrm{mm}^{-1}$

$\mathrm{F}(000)$

Crystal size $/ \mathrm{mm}^{3}$

Radiation yi3c

$\mathrm{C}_{27} \mathrm{H}_{52} \mathrm{BO}_{5} \mathrm{~F}_{4} \mathrm{PRu}$

675.54

$100.00(10)$

monoclinic

$\mathrm{I} 2 / \mathrm{a}$

16.7775(4)

9.6540(2)

$39.1720(11)$

90.00

$93.260(2)$

90.00

6334.4(3)

8

1.417

4.975

2832.0

$0.3068 \times 0.2254 \times 0.0989$

$\operatorname{CuK} \alpha(\lambda=1.54184)$

$2 \Theta$ range for data collection $/{ }^{\circ} 9.04$ to 149.48

Index ranges

Reflections collected

Independent reflections

Data/restraints/parameters

Goodness-of-fit on $\mathrm{F}^{2}$
$-20 \leq \mathrm{h} \leq 20,-11 \leq \mathrm{k} \leq 11,-48 \leq 1 \leq 48$

55980

$6382\left[\mathrm{R}_{\text {int }}=0.0867, \mathrm{R}_{\text {sigma }}=0.0312\right]$

$6382 / 0 / 372$

1.320

Final $R$ indexes $[\mathrm{I}>=2 \sigma(\mathrm{I})] \quad \mathrm{R}_{1}=0.0927, \mathrm{wR}_{2}=0.2173$

Final $\mathrm{R}$ indexes [all data] $\quad \mathrm{R}_{1}=0.0933, \mathrm{wR}_{2}=0.2175$

Largest diff. peak/hole / e $\AA^{-3} 2.01 /-3.04$ 
Table S17. Fractional Atomic Coordinates $\left(\times 10^{4}\right)$ and Equivalent Isotropic Displacement Parameters $\left(\AA^{2} \times 10^{3}\right)$ for $4 c . U_{\text {eq }}$ is defined as $1 / 3$ of of the trace of the orthogonalised $U_{I J}$ tensor.

\begin{tabular}{|c|c|c|c|c|}
\hline Atom & $x$ & $y$ & $z$ & $\mathbf{U}(\mathbf{e q})$ \\
\hline Ru1 & $3527.7(4)$ & $5291.1(7)$ & $1498.09(16)$ & $21.2(2)$ \\
\hline $\mathrm{P} 2$ & $3581.5(11)$ & $6073(2)$ & $952.3(5)$ & $17.1(4)$ \\
\hline F1 & $2366(4)$ & $-673(7)$ & $1485.9(16)$ & $49.2(17)$ \\
\hline $\mathrm{F} 2$ & $2053(4)$ & $791(8)$ & $1907.3(16)$ & $51.4(17)$ \\
\hline F3 & $3199(4)$ & $-462(9)$ & $1948.8(18)$ & $59(2)$ \\
\hline $\mathrm{F} 4$ & $3058(4)$ & $1312(8)$ & $1568(2)$ & $58(2)$ \\
\hline $\mathrm{O} 1$ & $4920(4)$ & $3516(8)$ & $1366.2(18)$ & $38.3(17)$ \\
\hline $\mathrm{O} 2$ & $2568(4)$ & $6649(8)$ & $1623.1(16)$ & $31.0(15)$ \\
\hline $\mathrm{O} 3$ & $3455(4)$ & $4666(9)$ & $2027.7(17)$ & $35.8(19)$ \\
\hline $\mathrm{O} 4$ & $2453(4)$ & $3865(8)$ & $1455.3(16)$ & $24.9(14)$ \\
\hline $\mathrm{C} 1$ & $4390(4)$ & $7310(10)$ & $883(2)$ & $21.5(18)$ \\
\hline $\mathrm{C} 2$ & $4282(5)$ & $8684(8)$ & $1086(2)$ & $17.6(16)$ \\
\hline $\mathrm{C} 3$ & 4949 ( 5 ) & $9703(8)$ & $1023(2)$ & $20.3(17)$ \\
\hline $\mathrm{C} 4$ & $5766(5)$ & $9062(10)$ & $1112(2)$ & $25.7(19)$ \\
\hline $\mathrm{C} 5$ & $5883(5)$ & $7744(10)$ & $907(2)$ & $24.4(18)$ \\
\hline C6 & $5231(5)$ & $6689(9)$ & $963(2)$ & $20.3(17)$ \\
\hline $\mathrm{C} 7$ & $3773(5)$ & $4661(9)$ & $645(2)$ & $21.0(18)$ \\
\hline $\mathrm{C} 8$ & $3821(5)$ & $5037(9)$ & $267(2)$ & $21.2(17)$ \\
\hline C9 & $4166(5)$ & $3831(10)$ & $67(2)$ & $24.1(18)$ \\
\hline $\mathrm{C} 10$ & $3697(5)$ & $2507(10)$ & $107(2)$ & $27(2)$ \\
\hline $\mathrm{C} 11$ & $3586(5)$ & $2160(10)$ & $479(2)$ & $25.8(19)$ \\
\hline $\mathrm{C} 12$ & $3245(5)$ & $3365(10)$ & $674(2)$ & $25.5(19)$ \\
\hline $\mathrm{C} 13$ & $2683(4)$ & $7057(9)$ & $806(2)$ & $19.7(17)$ \\
\hline C14 & $2734(4)$ & $7961(9)$ & $483(2)$ & $20.1(17)$ \\
\hline $\mathrm{C} 15$ & 1999 ( 5 ) & $8910(9)$ & $438(2)$ & $21.4(17)$ \\
\hline $\mathrm{C} 16$ & $1222(5)$ & $8059(10)$ & $424(2)$ & $23.0(18)$ \\
\hline $\mathrm{C} 17$ & 1185 ( 5 ) & $7125(10)$ & 735 ( 2 ) & $26.4(19)$ \\
\hline $\mathrm{C} 18$ & 1919 (5) & $6180(10)$ & 775 ( 2) & $25.1(19)$ \\
\hline
\end{tabular}




\begin{tabular}{|c|c|c|c|c|}
\hline C19 & $4361(5)$ & $4172(11)$ & $1416(2)$ & $29(2)$ \\
\hline $\mathrm{C} 20$ & $2106(6)$ & $6459(12)$ & $1922(2)$ & $36(2)$ \\
\hline $\mathrm{C} 21$ & $2720(6)$ & $4266(13)$ & $2180(2)$ & $37(3)$ \\
\hline $\mathrm{C} 22$ & $1774(5)$ & $4146(11)$ & $1658(2)$ & $28(2)$ \\
\hline $\mathrm{C} 23$ & 1994 ( 6) & $4937(12)$ & 1991 ( 2 ) & $32(2)$ \\
\hline $\mathrm{C} 24$ & $1280(6)$ & $4773(14)$ & $2221(3)$ & $47(3)$ \\
\hline B1 & $2674(7)$ & $256(13)$ & 1738 ( 3 ) & $34(3)$ \\
\hline O1S & $4274(4)$ & $6046(7)$ & $2513.2(16)$ & $32.7(15)$ \\
\hline $\mathrm{C} 1 \mathrm{~S}$ & $4616(5)$ & $5456(11)$ & $2757(2)$ & $28(2)$ \\
\hline $\mathrm{C} 2 \mathrm{~S}$ & $4703(7)$ & $3910(12)$ & 2778 ( 3 ) & $42(3)$ \\
\hline C3S & 4949 (7) & $6291(14)$ & $3052(3)$ & $49(3)$ \\
\hline
\end{tabular}

Table S18. Anisotropic Displacement Parameters $\left(\AA^{2} \times 10^{3}\right)$ for $4 c$. The Anisotropic displacement factor exponent takes the form: $-2 \pi^{2}\left[h^{2} a^{* 2} U_{11}+2 h k a * b * U_{12}+\ldots\right]$.

\begin{tabular}{|c|c|c|c|c|c|c|}
\hline Atom & $\mathbf{U}_{11}$ & $\mathbf{U}_{22}$ & $\mathbf{U}_{33}$ & $\mathbf{U}_{23}$ & $\mathbf{U}_{13}$ & $\mathbf{U}_{12}$ \\
\hline Rul & $16.1(3)$ & $30.6(4)$ & $17.0(3)$ & $0.7(3)$ & $0.7(2)$ & $-6.9(3)$ \\
\hline $\mathrm{P} 2$ & $12.2(9)$ & $21.0(11)$ & $18.0(9)$ & $1.6(8)$ & $0.8(7)$ & $0.2(8)$ \\
\hline $\mathrm{F} 1$ & $61(4)$ & $46(4)$ & $39(3)$ & $-8(3)$ & $-11(3)$ & $15(3)$ \\
\hline $\mathrm{F} 2$ & $47(4)$ & $65(5)$ & $44(4)$ & $-9(3)$ & $14(3)$ & $9(3)$ \\
\hline $\mathrm{F} 3$ & $45(4)$ & $70(5)$ & $60(4)$ & $14(4)$ & $-16(3)$ & $10(4)$ \\
\hline $\mathrm{F} 4$ & $46(4)$ & $45(4)$ & $87(5)$ & $16(4)$ & $21(4)$ & $8(3)$ \\
\hline $\mathrm{O} 1$ & $26(3)$ & $51(5)$ & $39(4)$ & 15 ( 3 ) & $7(3)$ & $9(3)$ \\
\hline $\mathrm{O} 2$ & $30(3)$ & $39(4)$ & $26(3)$ & $-1(3)$ & 11 ( 3 ) & $-3(3)$ \\
\hline $\mathrm{O} 3$ & $30(3)$ & $60(6)$ & $17(3)$ & $0(3)$ & $-1(3)$ & $-15(4)$ \\
\hline $\mathrm{O} 4$ & $20(3)$ & $31(4)$ & $23(3)$ & $-2(3)$ & $3(2)$ & $-2(3)$ \\
\hline $\mathrm{C} 1$ & $11(3)$ & $33(5)$ & $21(4)$ & $-3(4)$ & $0(3)$ & $0(3)$ \\
\hline $\mathrm{C} 2$ & $23(4)$ & $6(4)$ & $24(4)$ & $-3(3)$ & $3(3)$ & $2(3)$ \\
\hline $\mathrm{C} 3$ & $23(4)$ & $8(4)$ & $30(4)$ & $1(3)$ & $2(3)$ & $0(3)$ \\
\hline $\mathrm{C} 4$ & $19(4)$ & $29(5)$ & $29(4)$ & $-1(4)$ & $-1(3)$ & $-7(4)$ \\
\hline $\mathrm{C} 5$ & $13(4)$ & $30(5)$ & $30(4)$ & $-1(4)$ & $4(3)$ & $0(3)$ \\
\hline C6 & $16(4)$ & $18(4)$ & $28(4)$ & $4(3)$ & $1(3)$ & $-4(3)$ \\
\hline
\end{tabular}




\begin{tabular}{|c|c|c|c|c|c|c|}
\hline $\mathrm{C} 7$ & $13(3)$ & $30(5)$ & $19(4)$ & $5(3)$ & $0(3)$ & $1(3)$ \\
\hline $\mathrm{C} 8$ & $21(4)$ & $20(4)$ & $23(4)$ & $1(3)$ & $2(3)$ & $-6(3)$ \\
\hline C9 & $21(4)$ & $28(5)$ & $24(4)$ & $2(4)$ & $3(3)$ & $1(4)$ \\
\hline $\mathrm{C} 10$ & $24(4)$ & $28(5)$ & $31(5)$ & $-11(4)$ & $2(3)$ & $1(4)$ \\
\hline $\mathrm{C} 11$ & $26(4)$ & $19(5)$ & $32(5)$ & $1(4)$ & $7(4)$ & $4(4)$ \\
\hline $\mathrm{C} 12$ & $22(4)$ & $31(5)$ & $25(4)$ & $-3(4)$ & $7(3)$ & $-2(4)$ \\
\hline $\mathrm{C} 13$ & $15(4)$ & $26(5)$ & $18(4)$ & $0(3)$ & $0(3)$ & $-1(3)$ \\
\hline $\mathrm{C} 14$ & $14(4)$ & $24(5)$ & $23(4)$ & $0(3)$ & $2(3)$ & $0(3)$ \\
\hline $\mathrm{C} 15$ & $17(4)$ & $20(4)$ & $28(4)$ & $-3(3)$ & $3(3)$ & $7(3)$ \\
\hline $\mathrm{C} 16$ & $19(4)$ & $23(5)$ & $26(4)$ & $-2(4)$ & $-1(3)$ & $1(3)$ \\
\hline $\mathrm{C} 17$ & 15 ( 4 ) & $32(5)$ & $32(5)$ & $5(4)$ & $2(3)$ & $0(4)$ \\
\hline $\mathrm{C} 18$ & $16(4)$ & $34(5)$ & $26(4)$ & $-7(4)$ & $2(3)$ & $-6(4)$ \\
\hline C19 & $25(4)$ & $39(6)$ & $21(4)$ & $11(4)$ & $-5(3)$ & $-9(4)$ \\
\hline $\mathrm{C} 20$ & 41 ( 6 ) & $41(6)$ & $28(5)$ & $-7(4)$ & $19(4)$ & $-13(5)$ \\
\hline $\mathrm{C} 21$ & $31(5)$ & $60(7)$ & $21(4)$ & $9(5)$ & $3(4)$ & $-17(5)$ \\
\hline $\mathrm{C} 22$ & $17(4)$ & $39(6)$ & $28(4)$ & $-4(4)$ & $4(3)$ & $-7(4)$ \\
\hline $\mathrm{C} 23$ & $30(5)$ & $44(6)$ & $22(4)$ & $0(4)$ & $9(4)$ & $-8(5)$ \\
\hline $\mathrm{C} 24$ & $42(6)$ & $67(9)$ & $34(5)$ & $-10(5)$ & $20(5)$ & $-18(6)$ \\
\hline B1 & $31(5)$ & $34(7)$ & $36(6)$ & $4(5)$ & $6(4)$ & $4(5)$ \\
\hline $\mathrm{O} 1 \mathrm{~S}$ & $34(3)$ & $34(4)$ & $29(3)$ & $6(3)$ & $-3(3)$ & $-5(3)$ \\
\hline $\mathrm{C} 1 \mathrm{~S}$ & $22(4)$ & $36(6)$ & $27(4)$ & $0(4)$ & $5(3)$ & $-4(4)$ \\
\hline $\mathrm{C} 2 \mathrm{~S}$ & $40(6)$ & $42(7)$ & $46(6)$ & $2(5)$ & $11(5)$ & $4(5)$ \\
\hline $\mathrm{C} 3 \mathrm{~S}$ & $53(7)$ & $59(8)$ & $35(6)$ & $-9(6)$ & $-10(5)$ & $-12(6)$ \\
\hline
\end{tabular}

Table S19. Bond Lengths for 4c.

Atom Atom Length $/ \AA$ Atom Atom Length $/ \AA$

Ru1 P2 2.274(2) C5 C6 1.521(11)

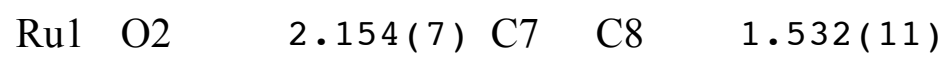

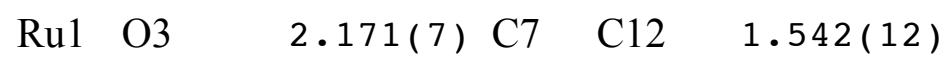

$\begin{array}{lllll}\mathrm{Ru} 1 \mathrm{O} 4 & 2.267(6) & \mathrm{C} 8 & \mathrm{C} 9 & 1.534(12)\end{array}$

Ru1 C19 1.810(10) C9 C10 1.514(13) 


$\begin{array}{llllll}\text { P2 } & \text { C1 } & 1.839(9) & \mathrm{C} 10 & \mathrm{C} 11 & 1.519(12) \\ \text { P2 } & \text { C7 } & 1.858(9) & \mathrm{C} 11 & \mathrm{C} 12 & 1.521(12) \\ \mathrm{P} 2 & \mathrm{C} 13 & 1.846(8) & \mathrm{C} 13 & \mathrm{C} 14 & 1.543(11) \\ \mathrm{F} 1 & \mathrm{~B} 1 & 1.409(14) & \mathrm{C} 13 & \mathrm{C} 18 & 1.534(11) \\ \mathrm{F} 2 & \mathrm{~B} 1 & 1.369(12) & \mathrm{C} 14 & \mathrm{C} 15 & 1.539(11) \\ \mathrm{F} 3 & \mathrm{~B} 1 & 1.363(13) & \mathrm{C} 15 & \mathrm{C} 16 & 1.540(11) \\ \mathrm{F} 4 & \mathrm{~B} 1 & 1.394(13) & \mathrm{C} 16 & \mathrm{C} 17 & 1.518(12) \\ \mathrm{O} 1 & \mathrm{C} 19 & 1.158(12) & \mathrm{C} 17 & \mathrm{C} 18 & 1.534(12) \\ \mathrm{O} 2 & \mathrm{C} 20 & 1.453(10) & \mathrm{C} 20 & \mathrm{C} 23 & 1.507(15) \\ \mathrm{O} 3 & \mathrm{C} 21 & 1.451(11) & \mathrm{C} 21 & \mathrm{C} 23 & 1.531(14) \\ \mathrm{O} 4 & \mathrm{C} 22 & 1.451(10) & \mathrm{C} 22 & \mathrm{C} 23 & 1.539(13) \\ \mathrm{C} 1 & \mathrm{C} 2 & 1.561(11) & \mathrm{C} 23 & \mathrm{C} 24 & 1.548(12) \\ \mathrm{C} 1 & \mathrm{C} 6 & 1.548(11) & \mathrm{O} 1 \mathrm{~S} & \mathrm{C} 1 \mathrm{~S} & 1.228(11) \\ \mathrm{C} 2 & \mathrm{C} 3 & 1.520(11) & \mathrm{C} 1 \mathrm{~S} & \mathrm{C} 2 \mathrm{~S} & 1.501(15) \\ \mathrm{C} 3 & \mathrm{C} 4 & 1.527(11) & \mathrm{C} 1 \mathrm{~S} & \mathrm{C} 3 \mathrm{~S} & 1.490(14) \\ \mathrm{C} 4 & \mathrm{C} 5 & 1.524(13) & & & \end{array}$

Table S20. Bond Angles for 4c.

\begin{tabular}{|c|c|c|c|c|c|c|c|}
\hline \multicolumn{3}{|c|}{ Atom Atom Atom } & \multirow{2}{*}{$\begin{array}{l}\text { Angle }^{\circ} \\
\quad 94.71(18)\end{array}$} & \multicolumn{3}{|c|}{ Atom Atom Atom } & \multirow{2}{*}{$\begin{array}{l}\text { Angle }^{\circ} \\
\quad 112.1(7)\end{array}$} \\
\hline $\mathrm{O} 2$ & Ru1 & $\mathrm{P} 2$ & & $\mathrm{C} 10$ & C9 & $\mathrm{C} 8$ & \\
\hline $\mathrm{O} 2$ & Ru1 & $\mathrm{O} 3$ & $82.4(3)$ & C9 & $\mathrm{C} 10$ & $\mathrm{C} 11$ & $112.2(7)$ \\
\hline $\mathrm{O} 2$ & Ru1 & $\mathrm{O} 4$ & $77.6(3)$ & $\mathrm{C} 10$ & $\mathrm{C} 11$ & $\mathrm{C} 12$ & $112.6(8)$ \\
\hline $\mathrm{O} 3$ & Ru1 & $\mathrm{P} 2$ & $176.6(2)$ & $\mathrm{C} 11$ & $\mathrm{C} 12$ & $\mathrm{C} 7$ & $110.4(7)$ \\
\hline $\mathrm{O} 3$ & Ru1 & $\mathrm{O} 4$ & $79.3(3)$ & $\mathrm{C} 14$ & $\mathrm{C} 13$ & $\mathrm{P} 2$ & $117.6(5)$ \\
\hline $\mathrm{O} 4$ & Ru1 & $\mathrm{P} 2$ & $101.88(17)$ & $\mathrm{C} 18$ & $\mathrm{C} 13$ & $\mathrm{P} 2$ & $113.8(6)$ \\
\hline $\mathrm{C} 19$ & Ru1 & $\mathrm{P} 2$ & $87.7(3)$ & $\mathrm{C} 18$ & $\mathrm{C} 13$ & $\mathrm{C} 14$ & $109.4(7)$ \\
\hline $\mathrm{C} 19$ & Ru1 & $\mathrm{O} 2$ & $176.8(3)$ & $\mathrm{C} 15$ & C14 & $\mathrm{C} 13$ & $110.5(6)$ \\
\hline $\mathrm{C} 19$ & Ru1 & $\mathrm{O} 3$ & $95.1(3)$ & $\mathrm{C} 14$ & $\mathrm{C} 15$ & $\mathrm{C} 16$ & $111.0(7)$ \\
\hline $\mathrm{C} 19$ & Ru1 & $\mathrm{O} 4$ & $104.1(4)$ & $\mathrm{C} 17$ & $\mathrm{C} 16$ & $\mathrm{C} 15$ & $111.2(7)$ \\
\hline $\mathrm{C} 1$ & $\mathrm{P} 2$ & Ru1 & $115.0(3)$ & $\mathrm{C} 16$ & $\mathrm{C} 17$ & $\mathrm{C} 18$ & $111.5(7)$ \\
\hline $\mathrm{C} 1$ & P2 & $\mathrm{C} 7$ & $103.0(4)$ & $\mathrm{C} 17$ & $\mathrm{C} 18$ & $\mathrm{C} 13$ & $110.0(8)$ \\
\hline
\end{tabular}




\begin{tabular}{|c|c|c|c|c|c|c|c|}
\hline $\mathrm{C} 1$ & $\mathrm{P} 2$ & $\mathrm{C} 13$ & $102.5(4)$ & $\mathrm{O} 1$ & C19 & $\mathrm{Ru} 1$ & $176.4(9)$ \\
\hline $\mathrm{C} 7$ & $\mathrm{P} 2$ & Ru1 & $112.5(3)$ & $\mathrm{O} 2$ & $\mathrm{C} 20$ & $\mathrm{C} 23$ & $110.2(8)$ \\
\hline $\mathrm{C} 13$ & $\mathrm{P} 2$ & Rul & $112.8(3)$ & $\mathrm{O} 3$ & $\mathrm{C} 21$ & $\mathrm{C} 23$ & $111.2(8)$ \\
\hline $\mathrm{C} 13$ & $\mathrm{P} 2$ & $\mathrm{C} 7$ & $110.2(4)$ & $\mathrm{O} 4$ & $\mathrm{C} 22$ & $\mathrm{C} 23$ & $113.6(7)$ \\
\hline $\mathrm{C} 20$ & $\mathrm{O} 2$ & Ru1 & $123.1(6)$ & $\mathrm{C} 20$ & $\mathrm{C} 23$ & $\mathrm{C} 21$ & $113.3(9)$ \\
\hline $\mathrm{C} 21$ & $\mathrm{O} 3$ & $\mathrm{Ru} 1$ & $124.1(5)$ & $\mathrm{C} 20$ & $\mathrm{C} 23$ & $\mathrm{C} 22$ & 110.9 (8) \\
\hline $\mathrm{C} 22$ & $\mathrm{O} 4$ & $\mathrm{Ru} 1$ & $119.4(6)$ & $\mathrm{C} 20$ & $\mathrm{C} 23$ & $\mathrm{C} 24$ & $108.3(9)$ \\
\hline $\mathrm{C} 2$ & $\mathrm{C} 1$ & $\mathrm{P} 2$ & $111.7(5)$ & $\mathrm{C} 21$ & $\mathrm{C} 23$ & $\mathrm{C} 22$ & $110.1(9)$ \\
\hline C6 & $\mathrm{C} 1$ & $\mathrm{P} 2$ & $112.9(6)$ & $\mathrm{C} 21$ & $\mathrm{C} 23$ & $\mathrm{C} 24$ & $107.3(8)$ \\
\hline C6 & $\mathrm{C} 1$ & $\mathrm{C} 2$ & $110.9(7)$ & $\mathrm{C} 22$ & $\mathrm{C} 23$ & $\mathrm{C} 24$ & $106.6(8)$ \\
\hline C3 & $\mathrm{C} 2$ & $\mathrm{C} 1$ & $111.1(6)$ & $\mathrm{F} 2$ & B1 & $\mathrm{F} 1$ & $108.7(9)$ \\
\hline $\mathrm{C} 2$ & $\mathrm{C} 3$ & $\mathrm{C} 4$ & $111.1(7)$ & $\mathrm{F} 2$ & B1 & $\mathrm{F} 4$ & $110.0(9)$ \\
\hline $\mathrm{C} 5$ & $\mathrm{C} 4$ & $\mathrm{C} 3$ & $111.0(7)$ & F3 & B1 & $\mathrm{F} 1$ & $107.4(9)$ \\
\hline C6 & $\mathrm{C} 5$ & $\mathrm{C} 4$ & $111.5(7)$ & F3 & B1 & $\mathrm{F} 2$ & $112.4(9)$ \\
\hline $\mathrm{C} 5$ & C6 & $\mathrm{C} 1$ & $111.4(7)$ & F3 & B1 & $\mathrm{F} 4$ & $111.2(9)$ \\
\hline $\mathrm{C} 8$ & $\mathrm{C} 7$ & $\mathrm{P} 2$ & $118.3(6)$ & $\mathrm{F} 4$ & B1 & $\mathrm{F} 1$ & $107.0(9)$ \\
\hline $\mathrm{C} 8$ & $\mathrm{C} 7$ & $\mathrm{C} 12$ & $109.1(7)$ & O1S & C1S & $\mathrm{C} 2 \mathrm{~S}$ & $122.9(9)$ \\
\hline $\mathrm{C} 12$ & $\mathrm{C} 7$ & $\mathrm{P} 2$ & $115.2(5)$ & O1S & $\mathrm{C} 1 \mathrm{~S}$ & $\mathrm{C} 3 \mathrm{~S}$ & $119.3(10)$ \\
\hline $\mathrm{C} 7$ & $\mathrm{C} 8$ & C9 & $110.8(7)$ & $\mathrm{C} 3 \mathrm{~S}$ & C1S & $\mathrm{C} 2 \mathrm{~S}$ & $117.8(10)$ \\
\hline
\end{tabular}

Table S21. Hydrogen Bonds for $4 \mathrm{c}$.

$\begin{array}{lcccc}\mathbf{D} \mathbf{H} \mathbf{A} & \mathbf{d}(\mathbf{D}-\mathbf{H}) / \AA & \mathbf{d}(\mathbf{H}-\mathbf{A}) / \AA & \mathbf{d}(\mathbf{D}-\mathbf{A}) / \AA & \mathbf{D}-\mathbf{H}-\mathbf{A} /{ }^{\circ} \\ \mathrm{O} 2 \mathrm{H} 2 \mathrm{~F}^{1} & 0.96(13) & 1.74(13) & 2.659(10) & 161(10) \\ \text { O3 H3 O1S } & 0.68(12) & 1.97(12) & 2.643(10) & 168(15) \\ \text { O4 H4 F4 } & 0.68(10) & 2.01(11) & 2.692(11) & 172(12)\end{array}$

Table S22. Torsion Angles for 4c.

$\begin{array}{llllllllll}\text { A } & \text { B } & \text { C } & \text { D } & \text { Angle } ~^{\circ} & \text { A } & \text { B } & \text { C } & \text { D } & \text { Angle } /^{\circ}\end{array}$

Ru1P2 C1 C2 -64.4(6) O4 Ru1O3 C21 -28.1(9)

Ru1P2 C1 C6 61.4(6) O4 Ru1C19O1 179(100)

Ru1P2 C7 C8 179.7(5) O4 C22C23C20 78.6(11) 


\begin{tabular}{|c|c|c|c|}
\hline $\mathrm{u} 1 \mathrm{P} 2 \mathrm{C} 7 \mathrm{C} 1$ & ) & $\mathrm{O} 4 \mathrm{C} 22 \mathrm{C} 23 \mathrm{C}$ & 17 \\
\hline u1 P2 C13C & $64.1(5)$ & $\mathrm{O} 4 \mathrm{C} 22 \mathrm{C} 23 \mathrm{C} 24$ & 1637 \\
\hline u1P2 C13C & ) & $\begin{array}{llll}\mathrm{C} 1 & \mathrm{P} 2 & \mathrm{C} 7 & \mathrm{C} 8\end{array}$ & \\
\hline $\mathrm{u} 1 \mathrm{O} 2 \mathrm{C} 20 \mathrm{C}$ & $5.6(11)$ & C1 1 P2 C7 C12 & $1727(6)$ \\
\hline $\mathrm{u} 1 \mathrm{O} 3 \mathrm{C} 21 \mathrm{C}$ & ) & $\mathrm{C} 1 \mathrm{P} 2 \mathrm{C}$ & $39.9(7)$ \\
\hline $\mathrm{u} 1 \mathrm{O} 4 \mathrm{C} 22 \mathrm{C}$ & $-26.9(11)$ & C1 P2 C13C18 & 16 \\
\hline $2 \mathrm{Ru} 1 \mathrm{O} 2 \mathrm{C} 20$ & $165.2(7)$ & $\begin{array}{llll}\mathrm{C} 1 & \mathrm{C} 2 & \mathrm{C} & \mathrm{C} \\
\mathrm{C}\end{array}$ & -5 \\
\hline $2 \mathrm{Ru} 1 \mathrm{O} 3 \mathrm{C} 21$ & ) & $\mathrm{C} 2 \mathrm{C} 1 \mathrm{C} 6 \mathrm{C} 5$ & \\
\hline $2 \mathrm{Ru} 1 \mathrm{O} 4 \mathrm{C} 22$ & $120.0(6)$ & $\mathrm{C} 2 \quad \mathrm{C} 3 \mathrm{C}_{4} \mathrm{C} 5$ & 57 \\
\hline P2 Ru1C19O1 & $77(12)$ & C3 C4 C5 C6 & 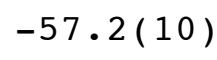 \\
\hline $2 \mathrm{C} 1 \mathrm{C} 2 \mathrm{C} 3$ & $179.3(5)$ & $\mathrm{C} 4 \mathrm{C} 5 \mathrm{C} 6 \mathrm{C} 1$ & $55.2(9)$ \\
\hline $2 \mathrm{C} 1 \mathrm{C} 6 \mathrm{C} 5$ & $-179.5(6)$ & C6 61 C2 23 & 53 \\
\hline $\begin{array}{llll}2 & \mathrm{C} 7 & \mathrm{C} 8 & \mathrm{C} 9\end{array}$ & $167.1(5)$ & $\mathrm{C} 7 \quad \mathrm{P} 2 \quad \mathrm{C} 1 \quad \mathrm{C} 2$ & 1. \\
\hline $2 \mathrm{C} 7 \mathrm{C} 12 \mathrm{C} 1$ & $-165.6(6)$ & $\mathrm{C} 7 \quad \mathrm{P} 2 \quad \mathrm{C} 1 \quad \mathrm{C} 6$ & \\
\hline $2 \mathrm{C} 13 \mathrm{C} 14 \mathrm{C}$ & $-169.3(6)$ & C7 P2 C13C14 & -69.2 \\
\hline $2 \mathrm{C} 13 \mathrm{C} 18 \mathrm{C} 1$ & 16 & C7 P2 C $13 \mathrm{C} 18$ & \\
\hline $2 \mathrm{Ru} 1 \mathrm{P} 2 \mathrm{C} 1$ & $9(4)$ & C7 $\mathrm{C} 8$ C9 $\mathrm{C} 10$ & 55 \\
\hline $\mathrm{O} 2 \mathrm{Ru} 1 \mathrm{P} 2 \mathrm{C} 7$ & ) & C8 C7 C12C11 & \\
\hline 2 Ru1P2 C1. & $-16.2(4)$ & C8 C9 C10C11 & \\
\hline $2 \mathrm{Ru} 1 \mathrm{O} 3 \mathrm{C} 2$ & (9) & C9 C10 & 2 \\
\hline $2 \mathrm{Ru} 1 \mathrm{O} 4 \mathrm{C} 2$ & $-27.8(6)$ & $\mathrm{C} 10 \mathrm{C} 11 \mathrm{C} 12 \mathrm{C} 7$ & - \\
\hline O2 Ru1c & $-60(15)$ & $\mathrm{C} 12 \mathrm{C} 7 \mathrm{C} 8 \mathrm{C} 9$ & -5 \\
\hline $\mathrm{O} 2 \mathrm{C} 20 \mathrm{C} 23 \mathrm{C} 2$ & $80.5(10)$ & $\mathrm{C} 13 \mathrm{P} 2 \quad \mathrm{C} 1 \quad \mathrm{C} 2$ & 58 \\
\hline $\mathrm{O} 2 \mathrm{C} 20 \mathrm{C} 23 \mathrm{C} 2$ & $43.9(11)$ & $\mathrm{C} 13 \mathrm{P} 2 \mathrm{C} 1 \mathrm{C} 6$ & -1 \\
\hline $\mathrm{O} 2 \mathrm{C} 20 \mathrm{C} 23 \mathrm{C} 2$ & $-160.5(8)$ & $\mathrm{C} 13 \mathrm{P} 2 \quad \mathrm{C} 7 \mathrm{C} 8$ & 52 \\
\hline O3 Ru1 P2 C1 & $69(3)$ & $\mathrm{C} 13 \mathrm{P} 2 \quad \mathrm{C} 7 \mathrm{C} 12$ & \\
\hline O3 Ru1P2 C7 & $-173(3)$ & $\mathrm{C} 13 \mathrm{C} 14 \mathrm{C} 15 \mathrm{C} 16$ & \\
\hline O3 Ru1P2 C1 & -48 & $\mathrm{C} 14 \mathrm{C} 13 \mathrm{C}$ & \\
\hline O3 Ru1O2 C20 & $-16.6(7)$ & $\mathrm{C} 14 \mathrm{C} 1$ & 54 \\
\hline $\mathrm{O} 3 \mathrm{Ru} 1 \mathrm{O} 4 \mathrm{C} 22$ & $56.8(7)$ & $\mathrm{C} 15 \mathrm{C} 16 \mathrm{C} 17 \mathrm{C} 18$ & $-55.4(1$ \\
\hline $3 \mathrm{Rl}$ & -1 & $18 \mathrm{C}$ & 5 \\
\hline
\end{tabular}


O3 C21 C23C20 -46.2(11) C18C13C14C15 58.8(9)

O3 C21C23C22 78.7(11) C19Ru1P2 C1 -76.9(4)

O3 C21C23C24 -165.6(9) C19Ru1P2 C7 40.6(4)

O4 Ru1P2 C1 179.1(4) C19Ru1P2 C13 166.0(4)

O4 Ru1 P2 C7 -63.3(3) C19Ru1O2 C20 -57(7)

O4 Ru1P2 C13 62.1(4) C19Ru1O3 C21 -131.5(9)

O4 Ru1O2 C20 64.0(7) C19Ru1O4 C22 149.4(7)

Table S23. Hydrogen Atom Coordinates $\left(\AA \times 10^{4}\right)$ and Isotropic Displacement Parameters $\left(\AA^{2} \times 10^{3}\right)$ for $4 c$.

\begin{tabular}{|c|c|c|c|c|}
\hline Atom & $x$ & $y$ & $z$ & $\mathbf{U}(\mathbf{e q})$ \\
\hline $\mathrm{H}$ & $4140(50)$ & $6460(100)$ & $1570(20)$ & $20(20)$ \\
\hline $\mathrm{H} 2$ & $2610(70)$ & $7630(130)$ & $1590(30)$ & $40(30)$ \\
\hline H3 & $3650(70)$ & $5110(140)$ & $2140(30)$ & $40(40)$ \\
\hline H4 & $2630(60)$ & $3250(110)$ & $1500(30)$ & $20(30)$ \\
\hline H1 & 4354 & 7554 & 635 & 26 \\
\hline $\mathrm{H} 2 \mathrm{~A}$ & 3762 & 9107 & 1014 & 21 \\
\hline $\mathrm{H} 2 \mathrm{~B}$ & 4281 & 8477 & 1333 & 21 \\
\hline $\mathrm{H} 3 \mathrm{~A}$ & 4882 & 10543 & 1163 & 24 \\
\hline H3B & 4916 & 9985 & 779 & 24 \\
\hline $\mathrm{H} 4 \mathrm{~A}$ & 6189 & 9737 & 1063 & 31 \\
\hline $\mathrm{H} 4 \mathrm{~B}$ & 5815 & 8844 & 1359 & 31 \\
\hline H5A & 5880 & 7977 & 660 & 29 \\
\hline H5B & 6409 & 7334 & 975 & 29 \\
\hline H6A & 5275 & 6371 & 1204 & 24 \\
\hline H6B & 5304 & 5875 & 815 & 24 \\
\hline $\mathrm{H} 7$ & 4323 & 4331 & 716 & 25 \\
\hline H8A & 4163 & 5865 & 246 & 25 \\
\hline H8B & 3281 & 5266 & 168 & 25 \\
\hline H9A & 4162 & 4079 & -178 & 29 \\
\hline H9B & 4728 & 3675 & 150 & 29 \\
\hline H10A & 3980 & 1734 & 0 & 33 \\
\hline
\end{tabular}




\begin{tabular}{|c|c|c|c|c|}
\hline H10B & 3167 & 2605 & -15 & 33 \\
\hline $\mathrm{H} 11 \mathrm{~A}$ & 4108 & 1892 & 591 & 31 \\
\hline H11B & 3223 & 1355 & 491 & 31 \\
\hline $\mathrm{H} 12 \mathrm{~A}$ & 3215 & 3109 & 918 & 31 \\
\hline H12B & 2697 & 3570 & 581 & 31 \\
\hline H13 & 2594 & 7728 & 995 & 24 \\
\hline $\mathrm{H} 14 \mathrm{~A}$ & 3225 & 8533 & 504 & 24 \\
\hline H14B & 2765 & 7359 & 280 & 24 \\
\hline $\mathrm{H} 15 \mathrm{~A}$ & 2028 & 9447 & 223 & 26 \\
\hline H15B & 1998 & 9573 & 630 & 26 \\
\hline H16A & 758 & 8695 & 415 & 28 \\
\hline H16B & 1190 & 7486 & 214 & 28 \\
\hline H17A & 697 & 6549 & 712 & 32 \\
\hline H17B & 1153 & 7702 & 943 & 32 \\
\hline H18A & 1936 & 5560 & 574 & 30 \\
\hline H18B & 1884 & 5598 & 982 & 30 \\
\hline $\mathrm{H} 20 \mathrm{~A}$ & 1578 & 6909 & 1884 & 43 \\
\hline H20B & 2386 & 6901 & 2123 & 43 \\
\hline $\mathrm{H} 21 \mathrm{~A}$ & 2744 & 4551 & 2423 & 45 \\
\hline $\mathrm{H} 21 \mathrm{~B}$ & 2664 & 3246 & 2171 & 45 \\
\hline $\mathrm{H} 22 \mathrm{~A}$ & 1521 & 3257 & 1716 & 33 \\
\hline $\mathrm{H} 22 \mathrm{~B}$ & 1377 & 4694 & 1519 & 33 \\
\hline $\mathrm{H} 24 \mathrm{~A}$ & 780 & 4940 & 2085 & 70 \\
\hline $\mathrm{H} 24 \mathrm{~B}$ & 1330 & 5442 & 2409 & 70 \\
\hline $\mathrm{H} 24 \mathrm{C}$ & 1277 & 3831 & 2315 & 70 \\
\hline $\mathrm{H} 2 \mathrm{SA}$ & 4378 & 3552 & 2958 & 64 \\
\hline $\mathrm{H} 2 \mathrm{SB}$ & 5264 & 3672 & 2830 & 64 \\
\hline $\mathrm{H} 2 \mathrm{SC}$ & 4523 & 3497 & 2558 & 64 \\
\hline H3SA & 5517 & 6078 & 3093 & 74 \\
\hline H3SB & 4664 & 6065 & 3256 & 74 \\
\hline H3SC & 4885 & 7279 & 3000 & 74 \\
\hline
\end{tabular}


